\title{
Metamorphism and the
}

Origin of Granitic Rocks

Northgate District

Colorado

GEOLOGICAL SURVEY PROFESSIONAL PAPER 274-M

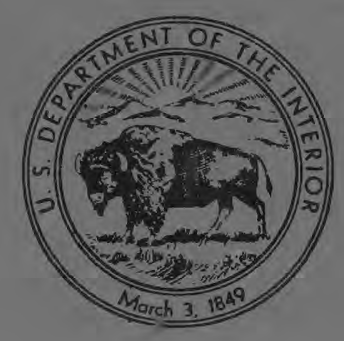




\section{Metamorphism and the}

Origin of Granitic Rocks

Northgate District

\section{Colorado}

By T. A. STEVEN

SHORTER CONTRIBUTIONS TO GENERAL GEOLOGY

GEOLOGICAL SURVEY PROFESSIONAL PAPER 274-M

$A$ discussion of the progressive metamorphism, granitization, and local rheomorphism of a layerea sequence of rocks, and of the later emplacement and deuteric alteration of an unrelated granitic stock

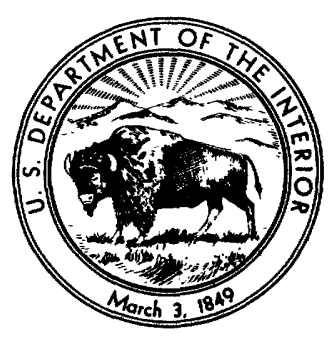

UNITED STATES GOVERNMENT PRINTING OFFICE, WASHINGTON : 1957 


\section{UNITED STATES DEPARTMENT OF THE INTERIOR}

FRED A. SEATON, Secretary

\section{GEOLOGICAL SURVEY}

Thomas B. Nolan, Director 


\section{CONTENTS}

Abstract._.

Introduction ............. 335

Acknowledgments._._.

Geologic setting . .

Pre-Cambrian geology

Hornblende gneiss _. . . . . .

Quartz monzonite gneiss............ 342

Biotite-garnet gneiss. . . . . . . . .

Pegmatite........... 350

Hornblende-biotite gneiss ...................... 353

Mylonite gneiss................. 354

Rheomorphic quartz monzonite gneiss_._. . . .

Petrography _. . .

Origin

Condition of rocks

Method of movement.

Direction of movement............... 363

Cause of movement.................. 364
Pre-Cambrian geology-Continued

Dacite porphyry

Intrusive quartz monzonite

Petrography _._. 365

Main body of the stock

Marginal dikes............ 366

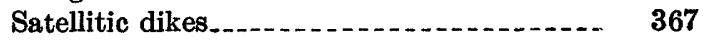

Wall-rock alteration

Origin............. 368

Emplacement. .

Original rock....... 370

Deuteric alteration

Late magmatic solutions................. 371

Summary and conclusions_..._.

Granitic rocks in the gneiss complex........... 373

Granitic rocks of magmatic origin

Literature cited..... 374

Index

\section{ILLUSTRATIONS}

[Plates 48-49 in pocket; plates 50-55 following page 378]

Puate 48. Geologic map of the Northgate district, Wyoming and Colorado.

49. Geologic map of the northwest part of the Northgate district.

50. Photomicrographs of hornblende gneiss.

51. View and photomicrographs of quartz monzonite gneiss.

52. Photomicrographs of biotite-garnet gneiss.

53. Photomicrographs of hornblende-biotite gneiss and mylonite gneiss.

54. Photomicrographs of rheomorphic quartz monzonite gneiss and intrusive quartz monzonite.

55. Photomicrographs of intrusive quartz monzonite.

FIGURE 67. Index map showing location of Northgate district.

68. Lineation in hornblende gneiss .

69. Lineation in hornblende-biotite gneiss and mylonite gneiss

70. Lineation in rheomorphic quartz monzonite gneiss .

\section{TABLE}

Tablis 1. Approximate specific gravities of pre-Cambrian rocks from the Northgate district. 



\title{
SHORTER CONTRIBUTIONS TO GENERAL GEOLOGY
}

\section{METAMORPHISM AND THE ORIGIN OF GRANITIG_ROGKS, NORTHGATE DISTRIGT, GOLORADO}

\author{
By T. A. Steven
}

\begin{abstract}
The pre-Cambrian rocks in the Northgate district on the western flank of the Medicine Bow Mountains, Colorado, consist of a gneiss complex invaded by a granitic stock. A few dacite porphyry dikes cut the gneiss complex and are older than the stock.

Dynamothermal metamorphism converted the parent rocks of the gneiss complex into a hornblende-plagioclase gneiss (hornblende gneiss), and was closely followed by widespread metasomatic transformations. Alkali and silica metasomatism converted relatively large masses of hornblende gneiss to quartz monzonite gneiss in the northern and southeastern parts of the district; smaller bodies of quartz monzonite gneiss were formed through the central part of the district where they are associated with abundant pegmatite of related metasomatic origin. Biotite-garnet-quartz-plagioclase gneiss (biotite-garnet gneiss) is a common associate of the pegmatite and was formed by local "basic" transformation of hornblende gneiss in a zone peripheral to the main zone of alkali metasomatism. Hydrothermal metamorphism of small ultramafic bodies developed a number of zoned deposits of serpentine, chlorite, tremolite-actinolite, and vermiculite.
\end{abstract}

Shearing during and after granitization reduced much of the rock in the gneiss complex to mylonite along an eastwardtrending zone through the south-central part of the district. Farther north, where shearing was less intense, only hornblende gneiss was much affected, and irregular bodies of hornblendebiotite-quartz-plagioclase gneiss (hornblende-biotite gneiss) were formed.

Some quartz monzonite gneiss in the large bodies in the northwestern and southeastern parts of the district became mobile after transformation and invaded the surrounding rocks. Relations are clearest near the northwest corner of the district where a funnel-shaped mass more than a mile in diameter forcibly injected and greatly deformed the adjacent rocks.

Several fine-grained dacite porphyry dikes, definitely older than the granitic stock, cut the gneiss complex in the vicinity of lower Camp Creek. The dikes follow tension fissures that do not conform to the structural pattern shown by the gneiss complex, and the dacite porphyry is believed to be unrelated to the other pre-Cambrian rocks in the district.

An intrusive granitic rock forms a stock and associated dikes in the central part of the Northgate district and several related dikes near the east edge of the district. Similar rocks are common in the Rocky Mountains of southern Wyoming and northern Colorado; and the stock is believed to be a cupola on a much larger underlying body. The original magma, which apparently was dioritic or quartz dioritic in composition, made way for itself by magmatic stoping. After solidification, the dioritic rock was pervasively deformed on a minor scale and invaded by alkali- and silica-bearing magmatic solutions which converted the main body of the stock into a biotite-quartz monzonite. Much of the biotite in the peripheral parts of the stock is chloritized, and the associated plagioclase is significantly more sodic than that in the central part of the stock. Wall-rock alteration was minor.

\section{INTRODUCTION}

This report deals largely with the progressive dynamothermal, metasomatic, and dynamic metamornhism, culminating in local rheomorphism, of a layered series of rocks, and with the later, unrelated emplacement of a dioritic stock and the deuteric alteration of this rock to quartz monzonite. All of these metamorphic and igneous rocks are of pre-Cambrian age; they comprise about two-thirds of the rocks exposed in the Northgate district, Colorado.

The Northgate district is in Jackson County, Colo., near the north end of North Park, a broad intermontane basin between the Medicine Bow Mountains and the Park Range of the southern Rocky Mountains (fig. 67). The district is largely on the western flank of the Medicine Bow Mountains, but also includes the northeast corner of North Park. The area covered by this report-about 65 square miles-is bounded roughly on the north by the Colorado State line, on the west by the North Platte River, on the south by the township line between Tps. 10 and $11 \mathrm{~N}$., and on the east by the range line between Rs. 78 and $79 \mathrm{~W}$., sixth principal meridian.

This report presents part of the results of an investigation by the U. S. Geological Survey centering on the fluorspar deposits of the district. The work began in 1943 as a strategic minerals investigation, when D. C. Cox, assisted by J. O. Fisher and J. W. Odell, made a preliminary study of the larger fluorspar deposits of the area. The vein zones were studied in more detail during 1944 and 1945 by D. C. Cox and W. E. Benson, assisted by D. M. Henderson, when the Geological Survey was working in cooperation with an exploratory program conducted by the U. S. Bureau of Mines. The writer visited the area briefly during the winter of $1945-46$, and spent about 


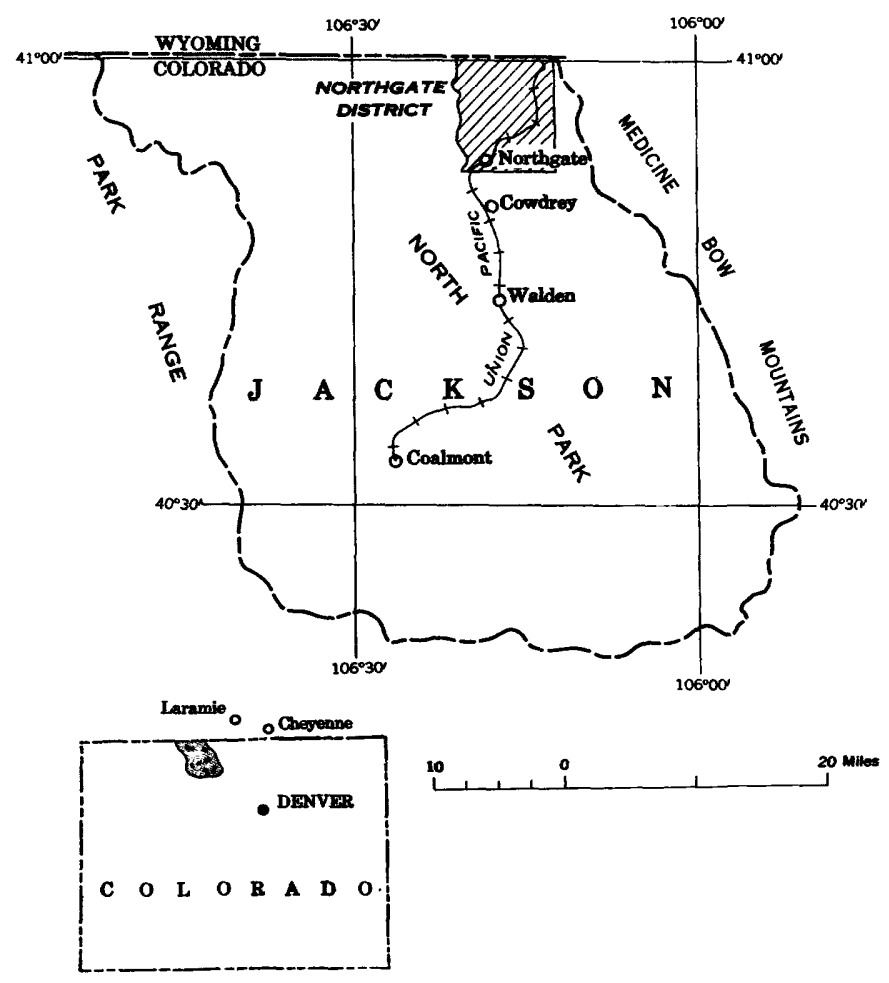

Froure 67.-Index map showing the location of the Northgate district, Colorado.

11 months during the field seasons of 1946, 1947, and 1948 studying the regional geology and fluorspar deposits. R. B. Johnson, A. L. Bush, and G. W. Weir assisted in this work. The results of the Bureau of Mines exploratory program have been published by Warne (1947). An unpublished report and geologic map of the fluorspar deposits was made by the Geological Survey. ${ }^{1}$ More extended, but still preliminary, discussions of the geology of the district have been published by Steven $(1953,1954)$.

Prior to the present investigation, almost no detailed geologic work had been done on the pre-Cambrian rocks in the vicinity. The broader features of North Park and the surrounding mountains were described briefly by Hague (in Hague and Emmons, 1877, p. 94-141) as part of the general reconnaissance done between 1867 and 1873 by the U. S. geological exploration of the 40th parallel. The coal resources and general geology of North Park were described by Beekly (1915), and although the report was based on only one season of field work done without an adequate base map, it is still the most complete account of the geology of North Park. Miller (1934) published the results of a more detailed study of the McCallum anticlines in east-central North Park. The fluorspar deposits have been described briefly by Ladoo (1923,

1 Cox, D. C., Benson, W. E. B., Steven, T. A., and Van Alstine, R. E., 1948, Flnorspar deposits of the Northgate district, Jackson County, Colo.: U. S. Geol. Survey Strategic Minerals Inv. Prelim. Map 3-220 [in flles of U. S. Geol. Survey]. p. 28-31; 1927, p. 116-119), Burchard (1933, p. 12-14), Cox (1945, p. 277), Cox, Benson, Steven, and Van Alstine, ${ }^{2}$ and Steven $(1953,1954)$. A note on the mineralogy of one of the fluorspar depcsits was published by Goldring (1942).

At the time of field work there was no adequate base map covering the Northgate district. Therefore the writer did most of the regional mspping on enlargements of U. S. Forest Service aerial photographs taken in 1937; some mapping in 1948 was done on aerial photographs taken for the Geolngical Survey in 1947. Section corners set during the General Land Office resurvey made in 1938-39 were located in the field, and a planimetric map was constructed using the General Land Office township plates for control. The resurvey did not cover the northern part of the Northgate district, and here the radial line method was used for map compilation. Control along the north edge of the map area is based upon the Colorado State line which was located in the field.

\section{ACKNOWLEDGMENTS}

The investigations leading to this report were carried on as part of the cooperative program of the U. S. Geological Survey and the Colorado Geological Survey Board and the Colorado Metal Mining Fund Board. On behalf of the U. S. Geological Survey geologists who have taken part in this investigation, the writer expresses appreciation for the help and cooneration given by the staffs of Kramer Mines, Inc., Western Fluorspar Corp., and later by Colorado Fluorspar Corp. The writer is especially appreciative of the many courtesies shown by M. P. Cloonan, resident manager, and C. E. Mitchell, of Colorado Fluorspar Corp.

The University of California at Los Angeles and the Department of Geology kindly furnished office space and laboratory facilities during the initial preparation of this report. The help and stimulation received from many discussions with graduate students and members of the faculty at the University are gratefully acknowledged.

\section{GEOLOGIC SETTING}

The metamorphic and igneous rocks of pre-Cambrian age that are exposed in the part of the western flank of the Medicine Bow Mountains covered by the Northgate district comprise a small part of the crystalline basement that underlies the whole so'ithern Rocky Mountain region. This basement is videly exposed in the cores of the broadly antictinal mountain ranges in central and northern Colorado and suuthern Wyo-

${ }^{2}$ Cox, D. C., Benson, W. E. B., Steven, T. A., and Van Altine, R. E., op. cit. 
ming, and it is generally buried by younger sedimentary rocks in the intervening basins.

Most of the metamorphic rocks in the basement are highly deformed and have relatively high metamorphic grades, and locally they have been pervasively transformed to migmatite: Granitic bodies of several ages, ranging in size from small dikes to great batholithic masses, cut the older metamorphic rocks. Although some of the migmatitic rocks occur in crude aureoles around granitic bodies and probably are genetically related to them, other migmatitic rocks show no apparent relation, either in space or origin, to granitic massifs. Many of the granitic bodies cut sharply across all the metamorphic rocks, including the migmatites, and appear distinctly younger and unrelated.

The pre-Cambrian rocks in the Northgate district were formed during at least two different periods in the long sequence of plutonic events that formed the crystalline basement of regional extent. These periods, one covering the complex metamorphism of the rocks in the gneiss complex, and the other the later emplacement and deuteric alteration of an intrusive quartz monzonite, however, comprise relatively complete genetic units in themselves, and the relations have considerable significance with respect to some of the basic problems of metamorphism and the origin of granitic rocks, as well as to the pre-Cambrian geology of the southern Rocky Mountains.

The pre-Cambrian rocks in the vicinity of the Northgate district were covered by a blanket of sedimentary rocks that was deposited during late Paleozoic, Mesozoic, and early Cenozoic time. These strata and the underlying crystalline rocks were strongly deformed during the Laramide orogeny in late Cretaceous and early Tertiary, when the essential structures of the Rocky Mountains were formed. The subsequent geologic history has been characterized by alternating erosion, valleyfill sedimentation, and minor deformation. The geologic relations of these younger features will be discussed fully in a more general paper by the writer on the Northgate district and will be summarized only briefly here to explain the different features shown on the geologic map (pl. 48).

Sedimentary rocks of Permian, Mesozoic, and early Tertiary age underlie the basin of North Park, and they are largely covered by a veneer of Quaternary terrace gravel, alluvium, and dune sand. These strata were first described in detail by Beekly (1915, p. 19-75). In the investigations leading to this report, some of the earlier subdivisions were revised to conform more closely to the stratigraphic units now differentiated in neighboring areas.

Two distinct stages of the Laramide orogeny that affected the Rocky Mountain area at the close of the
Cretaceous period and through early Tertiary time can be recognized in the Northgate district. The oldest stage of deformation outlined the general mountain and basin areas and compressed the sedimentary rocks into a series of northward- to northrestward-trending folds that lie almost parallel to the long axis of the North Park basin. Reverse faults cut and displace many of these folds. The second stage of deformation recognized was manifested by the Independence Mountain fault, a northward-dipping rererse fault that cuts almost at right angles across the trend of the earlier Laramide structures.

Tertiary formations of two ages fill old valleys cut in the pre-Cambrian rocks of the Northgate district. Light-gray to white tuffaceous clay and silt belonging to the White River formation of Oligocene age covered a maturely dissected area that marked the headwaters of a generally southward-flowing drainage system. Geomorphic changes subsequent to the deposition of the White River formation caused a reversal in the direction of drainage in middle Tertiary time, so that the valleys filled by clay, sand, and gravel of the North Park formation of Pliocene(?) age were cut by northward-flowing streams.

The region around the Northgate district was widely deformed on a minor scale in Pliocene time, following deposition of the North Park formation. The rocks were broadly warped and were offset along small, widely scattered faults. Fluorspar was deposited along at least two of these faults in the Northgate district, and locally it is abundant enough to comprise excellent commercial deposits.

Late Tertiary erosion cut a surface of low relief in the vicinity of the Northgate district, and many remnants are still preserved along the crest of the Medicine Bow Mountains. This surface evidently reachec? its most advanced geomorphic state in late Plioceng or early Pleistocene time, as it truncates structures that formed subsequent to the deposition of the North Park formation.

\section{PRE-CAMBRIAN GEOLOGY}

The pre-Cambrian rocks in the Northgate district consist of a gneiss complex cut by younger intrusive igneous bodies. The gneiss complex is exposed most widely in the northern half and along the eastern morgin of the district, but scattered exposures in the cores of anticlines within North Park suggest that it also urderlies large areas of sedimentary rocks in the district. The intrusive bodies are largest and most abundant in the central part of the district, but several moderstely sized bodies and small dikes also occur in the northeastern part of the district. 
The rocks in the gneiss complex formed under progressively changing conditions of metamorphism during a single orogenic period, and all appear to have been derived from closely related parent rocks. Dynamothermal metamorphism converted an originally layered sequence of rocks to a hornblende-plagioclase gneiss (hornblende gneiss), which later was transformed by shearing and metasomatic replacement into biotiteand quartz-bearing gneiss and schist and into quartz monzonite gneiss and pegmatite. The chief agents of metasomatic transformation were alkali- and silicabearing solutions which permeated the hornblende gneiss during a period of shearing that closely followed dynamothermal metamorphism. Some of the rock in the larger bodies of quartz monzonite gneiss became mobile late in the period of metasomatic transformation and invaded the neighboring rocks.

Several dikes of fine-grained dacite porphyry cut the gneiss complex near the lower part of Camp Creek. The dikes are older than the granitic rocks that comprise the largest and most abundant igneous bodies in the Northgate district, and apparently they are unrelated to the other pre-Cambrian rocks in the district.

A stock and associated dikes of quartz monzonite cut the gneiss complex in the central part of the district, and several related dikes occur near the east edge of the district. The rock in these bodies is distinct in appearance and occurrence, and apparently formed in an environment different from that in which the rocks in the gneiss complex formed. The rock was emplaced as a dioritic magma which made way for itself by magmatic stoping. After the dioritic rock solidified, it was brecciated and then invaded by alkaliand silica-bearing late magmatic solutions. The main body of the stock was converted to a biotite-microclineoligoclase-quartz monzonite; biotite commonly is chloritized and most of the plagioclase is albite in the peripheral zones. Wall-rock alteration was minor.

\section{HORNBLENDE GNEISS}

\section{GENERAL FEATURES AND DISTRIBUTION}

The hornblende gneiss consists essentially of hornblende and intermediate plagioclase; minor amounts of quartz, biotite, and augite occur locally. Hornblende gneiss grades into almost all other rocks in the gneiss complex, and field and petrographic relations indicate that most of the other metamorphic rocks were derived from it, either by metasomatic transformation or by shearing.

Hornblende gneiss is most abundant in the northern and northeastern parts of the district, where relatively unmodified masses a mile or more in diameter occur (pl. 48). Elsewhere, it has been extensively replaced by quartz monzonite gneiss, pegmatite, and other transformation products, and the hornblende gneiss forms irregular, relict masses of various sizes. The larger bodies commonly are interconnected, but many of the smaller bodies are isolated inclusions in pegmatite or quartz monzonite gneiss.

Small pods of massive chlorite, or chlorite and serpentine occur sporadically in hornblende gneiss. These bodies range from small clots a few feet 8 cross to pods 100 feet or more in diameter. The ultrsmafic masses were susceptible to hydrothermal metamorphism, and the margins of many pods have been altered to complexly zoned chlorite-tremolite-vermiculite bodies, and to talc-muscovite rocks.

\section{LITHOLOGY}

The hornblende gneiss is a dark medium-grained rock that crops out in blocky layers or "beds" ranging in thickness from several inches to several feet. The grains generally are less than 2 millimeters long, but some hornblende grains are 3 millimeters or more long. The layering is due to minor variations in bulk composition of the different layers rather than to mineral banding on the scale of individual grains. In most of the rock, hornblende and plagioclase are present ir nearly equal amounts, and fresh surfaces have a distir ctive pepperand-salt appearance. Some layers a few inches to several feet thick, however, differ greatly. Where hornblende predominates, the rock has a dark greenish-black cast and the scattered plagioclase crystals are glassy and in places almost colorless; in lighter colored varieties, the more abundant plagioclase tends to be white, although still quite glassy, and hornblende is in scattered crystals or clots of crystals. The long axes of hornblende prisms lie nearly parallel to the plane of larger scale layering, but the minerals generally are not segregated into bands and the foliation is poor. Hornblende pisms are well alined in some gneiss, but mineral lineation is weak or absent in much of the rock. Most plagioclase grains tend to be equidimensional, but some are elongate in the plane of layering.

The layering of the gneiss appears to have been an original feature of the rocks and is not due to metamorphic differentiation. Not only do the layers show minor crenulations and drag folds, but individual "beds" can be traced around the crests $\varepsilon$ nd troughs of larger folds. Some layers of light-colored plagioclaseand quartz-rich hornblende gneiss as much as $1 \frac{1}{2}$ feet thick are interbedded with the common, more mafic varieties. These rocks show no evidence of a secondary origin, and in all probability they origir ally had contrasting compositions.

Small chloritic pods, from a few feet to nearly a hundred feet in length and as much as 20 feet thick, are 
widely scattered and range from relatively pure, massive chlorite to variable mixtures of chlorite and hornblende. Grain size ranges from medium to very coarse with some chlorite crystals as much as an inch in diameter. Related small bodies of serpentine of about the same dimensions in the northwestern part of the district comprise a dense greenish-black rock that encloses abundant small aggregates of tremolite and olivine; much of the serpentine in these bodies is also altered to chlorite. Thin rims made up almost entirely of hornblende commonly separate the chlorite and serpentine bodies from normal hornblende gneiss, and these rims grade irregularly in to both the hornblende gneiss and the chlorite or serpentine bodies.

\section{PETROGRAPHY}

In thin section, the hornblende and plagioclase grains in hornblende gneiss form crystalloblastic aggregates with little mineral banding. Although most inequidimensional grains are elongated in the plane of foliation, good foliation is rarely apparent. Hornblende has a strong parallel orientation in some rocks, but more commonly the orientation is imperfect and in some rocks the texture is almost granoblastic.

Proportions of the component minerals vary so widely that an average composition has little meaning. Some of the rock is made up entirely of hornblende, whereas plagioclase forms 70 percent or more of other facies of the rock; in most specimens, however, plagioclase is somewhat more abundant than hornblende. Augite is rare, and where it occurs it generally makes up less than 5 percent of the rock, although about 15 percent of augite was seen in one specimen. Minor amounts of quartz and biotite are widely distributed, but in most rocks these minerals appear to have formed after dynamothermal metamorphism. Accessory minerals make up less than 1 percent of the hornblende gneiss. Of these, apatite is most abundant; sphene and magnetite are rare.

Most of the hornblende occurs in irregular and elongated grains and prisms (pl. 50, $A-C$ ). Acicular crystals are rare, and few prisms are more than three or four times longer than they are thick. Most grains are anhedral and interlock irregularly with adjacent grains of hornblende and plagioclase. In hornblenderich varieties some crystals are as much as 2 centimeters long, but generally the prisms are less than 3 millimeters. Some very fine grained varieties have few crystals more than 0.5 millimeter in diameter. The hornblende is optically negative with a moderately large $2 \mathrm{~V}$, estimated to be about $70^{\circ}$. Normally the angle of extinction $\mathrm{Z} \wedge c$ is between $15^{\circ}$ and $20^{\circ}$. The hornblende is strongly pleochroic, with the absorption generally $\mathrm{X}<\mathrm{Y}<\mathrm{Z}$, more rarely $\mathrm{X}<\mathrm{Y}=\mathrm{Z}$; the pleo402890-57-2 chroic colors are yellow to yellow green, light grass green, and dark grass green to bluish green. The intermediate index of refraction $(\beta)$ was measured for 14 specimens, and showed a range from about 1.64 to about 1.685. The two lowest measurements, near 1.64, however, were from coarse-grained hornblendic rocks that had recrystallized along the margins of pegmatite bodies; the range for the other 12 specimens was between 1.656 and 1.680, 3 measurements were bet- - een 1.660 and 1.670 and 6 measurements were betreen 1.670 and 1.680 .

Precise correlation of optical properties and chemical composition of amphiboles has not been achieved, but the properties listed above are characteristic of many "normal" hornblendes. Tweto, ${ }^{3}$ using all of the information from the literature, plotted composition agai ust mean index of refraction $\left(\frac{\alpha+\beta+\gamma}{3}\right)$ for the major oxides of the hornblende group. Although the points are somewhat scattered, median lines could be drawn that permit approximating the quantity of the major oxides present within a few percent by determining the mean index of refraction. The accuracy of these curves was tested during the present investigation using new chemical and optical data recorded by Buddingtor and Leonard (1953) for seven amphiboles from the Adirondack Mountains. The new data from the Adiron lack Mountains plotted well within the spread of data originally compiled by Tweto, and the average percentage deviations appeared to be of the same order of magnitude.

Using the curves compiled by Tweto and assuming that the intermediate indices $(\beta)$ determined are close to the mean indices, the compositions of the l nrnblendes from the Northgate district appear to be near the middle of the hornblende compositional renge. The indicated ranges in quantity of the major oxides in the hornblendes from the Northgate district are tabulated as follows:

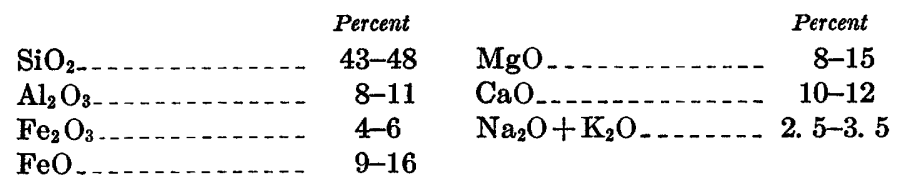

The plagioclase in most of the hornblende gneiss is calcic andesine $\left(\mathrm{An}_{40-45}\right)$, but the composition ranges between sodic andesine $\left(\mathrm{An}_{30}\right)$ and sodic labradorite $\left(\mathrm{An}_{55}\right)$. The more calcic plagioclase is generally in hornblende-rich gneiss, but some rocks with about equal proportions of hornblende and plagioclase also contain labradorite. Most plagioclase is in clear, irregular to almost equidimensional crystals that range

\footnotetext{
3 Tweto, O. L., 1947, Pre-Cambrian and Laramide geology of the Vasquez Moun
} tains, Colorado: Unpublished thesis, University of Michigan. 
from 0.5 to 2 millimeters in diameter (pl. $50, A-C$ ). Most of the plagioclase determinations were made by measuring extinction angles on grains of known orientation. Grains cut normal to the $a$ crystal axis were found particularly useful. The abundance and random orientation of plagioclase in most rocks permit close determination of at least several crystals in each thin section by this method. A few determinations were made by measuring indices of refraction.

Augite forms small, irregular, essentially colorless grains, generally less than 1 millimeter in diameter, that are closely associated with hornblende (pl. $50 \mathrm{C}$ ). Some augite grains are irregularly rimmed by pale actinolitic amphibole, but these rims are not common. The augite is optically positive, with a $2 \mathrm{~V}$ estimated to be near $60^{\circ}$. The maximum extinction angle $\mathrm{Z} \wedge c$ is between $45^{\circ}$ and $50^{\circ}$.

Rounded blebs of quartz embay hornblende and plagioclase and in places form abundant small poikiloblastic inclusions in hornblende (pl. $50 \mathrm{~B}$ ). Locally, small cuspate grains of quartz associated with minor amounts of microcline partly replace the older, larger crystals. Some quartz may be an original constituent of the gneiss, but most of the quartz appears to have been introduced after the hornblende and plagioclase crystallized.

Where present, biotite generally is associated with hornblende. In places it forms imperfect pseudomorphs after the hornblende, but more commonly it occurs as flakes and sheaves along cleavage planes or crystal margins of the hornblende. No biotite was found in augite-bearing hornblende gneiss. Some of the biotite may have been original in the gneiss, but most apparently formed during the period of metasomatic alteration and shearing that followed dynamothermal metamorphism. Some biotite grains are about as large as the associated hornblende (1-3 millimeters), but most are somewhat smaller, less than 0.5 millimeter in diameter.

Apatite, in small stubby prisms, is scattered through almost all hornblende gneiss, but nowhere does it exceed a fraction of a percent of the rock. Magnetite and sphene are even less abundant and in places appear to be secondary. Secondary epidote in small irregular grains and aggregates is scattered through the rock.

Although many of the chloritic pods in the hornblende gneiss retain little evidence of their origin, some clearly were formed from hornblende-rich masses of rock, and all stages in the alteration can be seen. Hornblende was altered to chlorite, magnetite, and epidoteclinozoisite; the subordinate plagioclase was highly saussuritized and sericitized, and commonly was almost completely altered. The massive chlorite com- monly contains small amounts of epidote, green spinel, and magnetite, most of which is titaniferous as shown by a dense, white "leucoxene" type of alteration product.

The serpentine bodies are made up in large part of very fine grained fibrous chrysotile containing abundant dusty to granular magnetite and hematite. Irregular and partly serpentinized aggregates of tremolite and olivine with abundant accessory magnetite and spinel are scattered throughout the serpentine, and scattered flakes of chlorite with associated magnetite cut both the serpentine and the tremolite-olivine relicts. Prismatic tremolite and rounded to irregular olivine grains occur in crystalloblastic aggregates that are clearly older than the serpentine. Olivine was more easily altered than tremolite, and in many of the partly altered rocks olivine was largely replaced by pseudomorphs of chrysotile. In the more completely altered rocks tremolite also was serpentinized, spinel disappeared during serpentinization, and magnetite was largely recrystallized.

\section{STRUCTURE}

Although the hornblende gneiss is distinctly layered, it lacks key beds or distinctive horizon markers. It was greatly deformed during dynamotl ormal metamorphism and was so changed in later shearing and metasomatic transformations that much of the evidence for determining the detailed structure of the rocks has been lost. Foliation and layering trend easterly and northeasterly and generally dip steeply northward. Axial parts of folds were observed throughout the areas underlain by hornblende gneiss; these structures ranged from small drag folds to large isoclinal folds with amplitudes much greater than the areas of outcrop and probably in terms of several thousands of feet. Foliation is parallel to the layering over most of the area, but in some places the foliation apparently transects the axial parts of folds.

All fold axes in the hornblende gneiss $\mathrm{p}^{\top}$ unge steeply, generally about down the dip of the foliation. The orientations of 31 random fold axes plotted on the lower hemisphere of a Schmidt equiarea net (fig. 68) fall within a relatively small area, and it is simnificant that no measurement deviates far from the ragional trend. Lineation shown by oriented prismati; hornblende crystals conforms to the same pattern, and the orientation of 18 random measurements also is shown on figure 68. Thus the mineral lineation is parallel to the tectonic axis defined by the fold axes, and according to interpretations widely but not univers lly accepted the direction of tectonic movement me,y have been largely horizontal. Lineations developed during the subsequent dynamic metamorphism and rheomorphism 


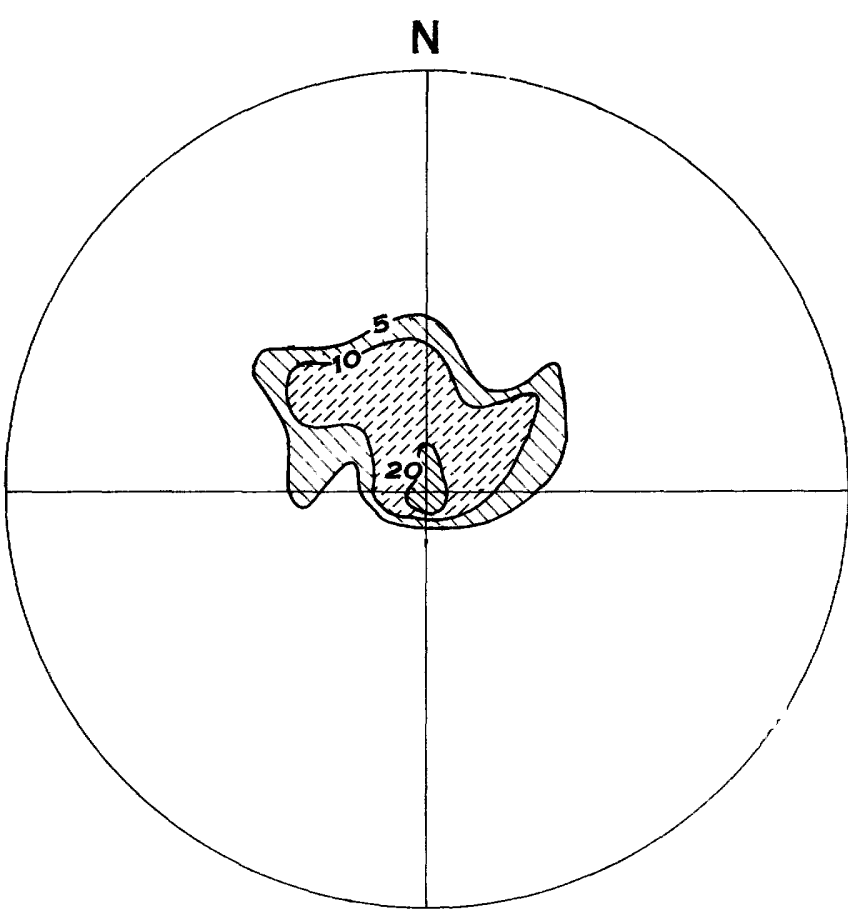

Lineation shown by 18 random measurements of oriented hornblende crystals

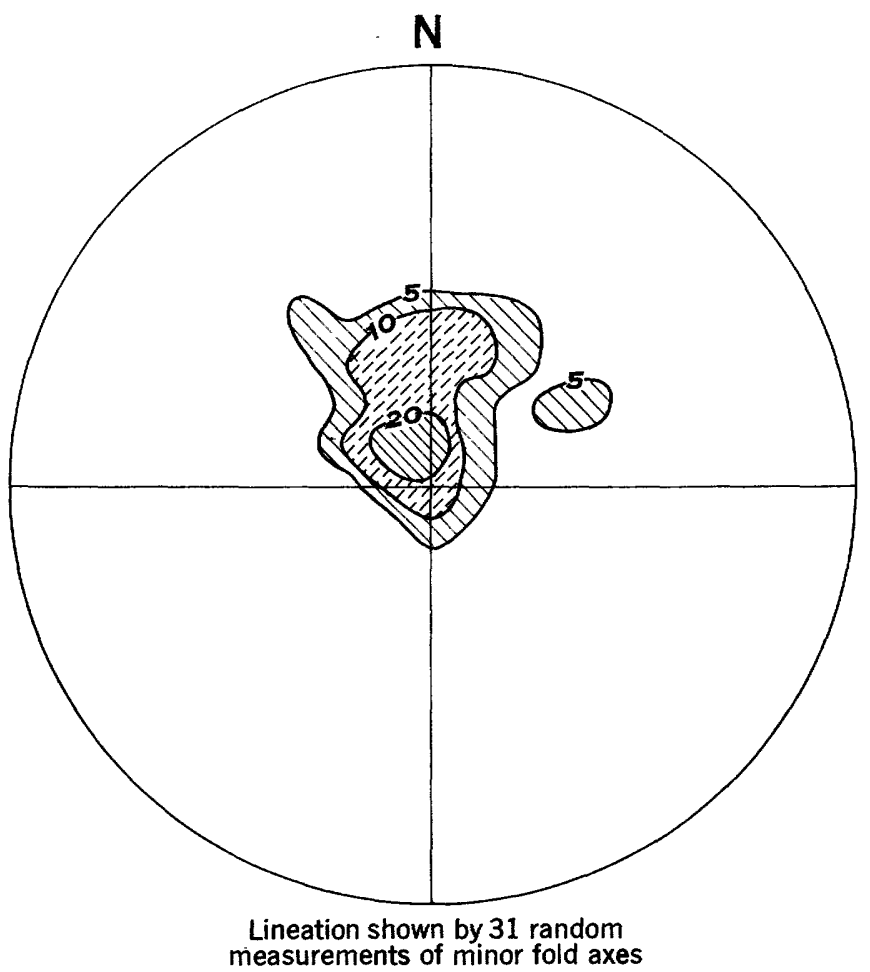

Ficure 68.- Lineation in hornblende gneiss. Contours on 5, 10, and 20 percent concentrations per 1 percent of the area. Plotted on the lower hemisphere of a Schmidt equiares net. are parallel to lineation in the regionally metamorphosed hornblende gneiss; apparently the same stress field persisted after the close folding and dynamothermal metamorphism ceased.

\section{ORIGIN}

Similar hornblende-rich rocks from many other places in the pre-Cambrian of Colorado and southern Wyoming have been described by many geolorists. According to Blackwelder (in Darton and others, 1910), the most abundant metamorphic rocks in the Laramie and Sherman quadrangles are dark gremnish hornblende schist; they are abundant on Jelm Mountain along the west edge of the Laramie quadrangle and 12 to 15 miles northeast of the Northgate district. From Blackwelder's description, these rocks appear identical with the hornblende gneiss in the Nortl rate district. By analogy with similar rocks in other districts, Blackwelder suggested that they are metamorphosed basic dikes and lava flows.

Ball (1906, p. 376; and in Spurr and others, 1908, p. 45-46) first described hornblende gneiss in the central part of the Front Range, Colorado. He noted that the rock occurred as sheets and dikes and believed it to be metamorphosed mafic igneous rocks. Lovering (1935, p. 10-11) described a similar hornblende gneiss in the Montezuma quadrangle, Colorado, where the hornblende gneiss is essentially conformable with the underlying Idaho Springs formation. Lovering suggested that it originated through the metamorr hism of andesitic flows. Tweto ${ }^{4}$ made a detailed study of the hornblende gneiss in the Vasquez Mountains, north of the Montezuma area. Here bands of hornb $b^{1}$ ende gneiss alternate with gneiss and schist of the metasedimentary Idaho Springs formation. After carefully considering the field relations, the variations and limits of composition, and the common association with limesilicate rocks, Tweto concluded that the hornb'ende gneiss resulted from the metamorphism of impure dolomite.

Hornblende-plagioclase rocks in other metamonphic terranes have been derived from both igneous and sedimentary rocks. The well-known amphibolites in the Grenville series in New York, Ontario, and Quebec have been attributed (Adams and Barlow, 1910; Buddington, 1939, p. 11-12; Osborne, 1936, p. 197-227) to the metamorphism of impure calcareous sedim onts, gabbros and diorites, and volcanic flows and tuffs

Hornblende gneiss in the Northgate district is so highly metamorphosed and was so greatly changed by later transformations that any discussion of origin largely would be conjecture. The present strusture 1 Tweto, O. L., op. cit. 
and mineralogy are due to intense deformation and inetamorphisin of what appears to have been originally a layered rock. The composition shows wide variation similar to that observed by Tweto, but no unequivocal metasedimentary rocks were found associated with it. Soine dense clinozoisite-epidote-quartz rocks that inay have been lime-silicate rocks of sedimentary origin occur in the belt of recrystallized inylonites along Pinkhain Creek Canyon, but the relations now are greatly obscured by cataclasis and granitzation. The residual tremolite-olivine-spinel aggregates in the serpentine bodies have been coinpletely recrystallized, and no relict texture survives. On the basis of coinposition, however, these bodies could well represent metamorphosed ultrainafic igneous rocks.

Although the composition of the different layers in the hornblende gneiss shows inore variation than might be expected in a series of lava flows, it is perhaps even inore difficult to envisage a sequence of impure calcareous rocks as thick as required in the Northgate district without some interbedded clastic sedinnents of distinctive character. The occurrence of serpentine bodies of possible ultramafic igneous origin suggests that the associated hornblende-plagioclase rocks also may have been of igneous origin. A mixed accuinulation of pyroclastic deposits and lava flows might approximate fairly closely the varied yet related coinpositions now displayed by the different layers of hornblende gneiss.

\section{QUARTZ MONZONITE GNEISS}

\section{GENGRAL FEATURES AND DISTRIBUTION}

Much of the hornblende gneiss in the Northgate district was converted by metasomatisin to a granitoid gneiss of quartz inonzonitic composition, and inany bodies have a distinctly pegmatitic facies. Abundant pegmatite, also believed to be inetasomatic in origin, is closely associated with the quartz inonzonite gneiss. The intricate shapes of the quartz monzonite gneiss bodies shown on the geologic inap (pl. 48) actually are generalizations, as it was impossible during field work to show all the details on aerial photographs with the approximate scale of 1 inch equals 1,000 feet.

According to interpretations outlined later in this report, some of the quartz monzonite gneiss near the northwestern and southeastern corners of the Northgate district became nobile (or rheomorphic) late in the period of inetasomatism and invaded the surrounding rocks, The rheomorphism was irregular, and the areas of once-mobile rocks are very poorly defined. These rocks, therefore, have not been differentiated on the geologic nap (pl. 48) but are included within the areas shown as quartz monzonite gneiss.
Large tabular bodies of quartz monzonite gneiss occur in the northern part of the district, and part of an irregular body occurs in the southeast corner. Reconnaissance in adjacent areas showed that these bodies are parts of much larger inasses of quartz inonzonite gneiss. There are numerous small bodies of quartz inonzonite gneiss in the central part of the Northgate district, between the larger inasses, but they are subordinate to the abundant pegmatite.

The quartz inonzonite gneiss was formed without deformation of the surrounding rocks except near masses that became inobile after transformation. Reinnants of hornblende gneiss abound in the transformed rocks, and relict textures can be recognized even in the interiors of some of the larger bodies. The transitions between quartz monzonite gneiss and the other inetanorphic rocks on one hand and pegmatite on the other are commonly so gradational that many of the unapped contacts are arbitrary. This gradation is comnnon along the strike of folitation of the quartz inonzonite gneiss bodies; across the strike inany of the contacts are fairly sharp. Most of the larger bodies of quartz inonzonite gneiss are relatively inassive and "granitic" appearing, whereas many of the smaller bodies inapped are incompletely transfcmed rocks that in the field resembled quartz inonzonite gneiss more than the original metamorphic rock. The pervasive solutions responsible for the trensformation altered the original minerals and introduced new minerals along the margins of the older grrins; little or no lit-par-lit gneiss or veined gneiss is ass ociated with the large bodies of quartz monzonite gneiss. After transformation froin hornblende gneiss to quartz inonzonite gneiss, the rock in the large mass near the northwest corner of the district became mobile and invaded the surrounding rocks (see "Pheomorphic quartz inonzonite gneiss"). Similar ınobilization took place near the southeastern part of the district, but apparently on a inuch sinaller scale.

\section{LITHOLOGY}

Quartz monzonite gneiss includes a dive"sified group of inedium-grained pink rocks composed doininantly of feldspar and quartz with minor amounts of biotite or chlorite. The incompletely transformed roeks differ inost in appearance, but even thoroughl $\%$ granitized rocks range widely in texture, grain size, and mineral composition. Most of the roek is layered or gneissose, and three general textural varieties were recognized in the field. The most distinctive variety shows a faint relict texture that resembles that of the original hornblende gneiss, but this generally is sul ordinate to gneissose and alaskitic varieties which have entirely new textures. 
All stages of transition between quartz monzonite gneiss and hornblende gneiss were traced in the field. The relationship is most apparent in those rocks that retained a relict texture through the transformations; the original hornblende was progressively altered to biotite or chlorite and the total content of mafic minerals diminished sharply, some quartz and microcline were introduced, but the rocks as a whole retained a marked textural resemblance to the original hornblende gneiss. The similarity seems dependent largely upon the plagioclase grains which became more albitic during transformation but retained their crystal form and served as a relict skeleton upon which the newly formed minerals were formed.

The rock with relict texture is made up of an aggregate of nearly equidimensional grains of quartz and feldspar (chiefly plagioclase), as much as 2 millimeters in diameter and small quantities of biotite or chlorite. The gneissic texture is due chiefly to a faint layering owing to variations in grain size and mineral composition, and to the elongation of some quartz grains and aggregates in the direction of foliation. Biotite and chlorite generally are too sparse to affect the foliation, but the few grains present tend to be oriented parallel to the layering shown by the other minerals. Pegmatite layers as much as 2 inches thick are common and generally follow the foliation.

Relict textures are absent in the other two closely related textural varieties, which are distinguished by their degree of foliation which in turn is controlled largely by the relative abundance of biotite. Where biotite makes up more than 5 percent of the rock, most of the flakes are oriented nearly parallel to the original layering of the metamorphic rocks and the foliation is fair to good; where biotite is minor or absent, the rock is distinctly alaskitic. The biotite present generally is rather evenly distributed through the rock, but in a few rocks it tends to be aggregated into biotite-rich layers. Quartz and feldspar grains in both the gneissose and alaskitic rocks are in even-grained aggregates and show little directional orientation. Some quartz grains are elongate in the direction of foliation, but most tend to be equidimensional. As in the rock which shows relict textures, thin layers of coarser gneiss and pegmatite are abundant and generally follow foliation. These rocks appear fairly uniform in hand specimens, but most outcrops show slight textural variations that give the rock a layered appearance.

The several textural varieties are closely associated, and gradations are common. The variety characterized by faint relict textures is absent near quartz monzonite gneiss that became mobile; but where the rocks were relatively undisturbed, different varieties occur in adjacent layers, even in the interior of large masses of quartz monzonite gneiss. Plate 51A shows typical quartz monzonite gneiss exposed in a fresh road cut.

In addition to the somewhat coarser bands of quartz monzonite gneiss, many bodies contain abundant irregular masses of pegmatite, and some smaller bodies pass laterally into pegmatite. In field mapping the different bodies were arbitrarily assigned to either quartz monzonite gneiss or pegmatite, depending on the dominant rock type.

\section{PETROGRAPHY}

The textural varieties of quartz monzonite gneiss differ considerably in mineral content. The gneiss with relict textures has significantly less microcline than plagioclase, and biotite or chlorite generally are subordinate. Albite or oligoclase is largely in corroded pseudomorphs after the plagioclase of the original hornblende gneiss; locally such plagioclase grains still make up 30 to 35 percent of the rock. Gneiss with new textures, on the other hand, generally has microcline-plagioclase ratios of $1: 1$ or greater and the gneissose and alaskitic varieties differ chiefly in biotite content. Plagioclase occurs as corroded relicts in these rocks too, but more complete replacement has destroyed the original textures of the rock. Ouartz varies widely in abundance but makes up 30 to 45 percent of most quartz monzonite gneiss.

Other differences in composition of quartz mor zonite gneiss apparently are related to variations in soda and potash concentration in the alkali- and silicabearing solutions which caused its transformation. Where potash was predominant, the resulting: rock characteristically consists of microcline, sodic oligoclase, quartz, and biotite; where soda was relstively more abundant the rock is made up of microcline, sodic albite, quartz, and chlorite. Most quartz monzonite gneiss formed under potash-rich conditions shows new textures but some has retained relict textures; most gneiss altered by soda-rich solutions has retained relict textures and only some show new textures. The mineralogic transformations transitional between hornblende gneiss and quartz morzonite gneiss differed greatly between potassic and sodic conditions of origin.

Spatial relations of the different textural and compositional trpes and the succession of mineralogic transformations, discussed in the following paragraphs, indicate that sodic conditions may have been peripheral to potassic conditions and that the inner and presumably higher temperature zones tended to enroach on the outer zones as the transformations progressed.

Potash was the predominant alkali in the formation of most quartz monzonite gneiss. In early sta ges of 
the transformation, hornblende was converted to biotite, plagioclase was altered to a somewhat more sodic feldspar crowded with saussuritic and sericitic inclusions, and considerable quartz was introduced. With continued alteration, microcline was introduced along the margins of the older grains, and biotite was progressively destroyed. Plagioclase was progressively replaced by microcline and some additional quartz and was converted to sodic oligoclase or calcic albite having relatively abundant myrmekite (pl. $51 B, C$ ). Typical thoroughly transformed gneiss of this origin consists of 25 to 50 percent microcline, 10 to 35 percent sodic oligoclase, 30 to 45 percent quartz, and as much as 15 percent biotite. Muscovite and garnet locally make up several percent of some quartz monzonite gneiss but generally are very subordinate or absent.

Soda-bearing solutions were most effective early in the period of transformation and were followed by progressively more potash-rich solutions. In early stages of alteration (pl. $50 D$ ), hornblende was converted largely to chlorite, in places through intermediate actinolite, plagioclase was altered to sodic albite crowded with saussuritic and sericitic inclusions, some quartz generally was introduced, and in places minor quantities of microcline were introduced. Some albite recrystallized during this state and albite-rich stringers with pegmatitic texture are relatively common, but most of the intermediate rock shows excellent relict hornblende gneiss texture.

Scattered granules and veinlets of epidote are abundant. With continued alteration, microcline and more quartz were introduced, and the quantity of chlorite diminished markedly with an increase in microcline content. Saussuritic inclusions in plagioclase in the more altered rocks are very irregularly distributed, and clear to partly clear plagioclase grains are common. Microcline generally makes up only 20 to 30 percent of the quartz monzonite gneiss of this origin, and relict textures are common. The rest of the rock typically is made up of 25 to 35 percent sodic albite, 35 to 45 percent quartz, and as much as 5 percent chlorite and epidote.

Plagioclase in all varieties of quartz monzonite gneiss forms irregular grains that characteristically are embayed by microcline and quartz (pl. $51 B, C)$. Some crystals are 2 millimeters in diameter, but most are between 0.5 and 1.5 millimeters in diameter. The plagioclase in rocks that formed under predominantly potassic conditions ranges in composition from $\mathrm{An}_{8}$ to $\mathrm{An}_{15}$; the plagioclase grains in rocks where early soda metasomatism was widespread generally are more sodic than $\mathrm{An}_{5}$. Saussuritic and sericitic inclusions in plagioclase generally decrease in abundance with an increase in the degree of albitization. This is particularly true in the more sodic plagioclase, but some relatively calcic oligoclase is clear also. Myrmekite is widespread through quartz monzonite gneiss and gen erally is along the margins of plagioclase grains adjacent to microcline (pl. 51C). It is therefore most abundant where microcline is most abundant, and is relatively rare in albitebearing rocks. All plagioclase crystals \&re highly corroded, and evidence from transitional rocks indicates that most grains are sodic pseudomorph ${ }^{\text {s }}$ of the intermediate plagioclase in the original hornblende gneiss.

Irregular grains of microcline range from minor intergranular wisps to relatively large pegmatitic poikiloblasts an inch or more in diameter that commonly contain abundant residual inclusions of unreplaced plagioclase and biotite. Many contacts indicate replacement relations toward plagioclase and biotite (pl. $51 B, C)$ and gradations in the progressive replacement have been observed. Most of the textural banding noted in outcrops and in hand specimens of quartz monzonite gneiss is due to greater concentration of microcline by metasomatic replacement of primary minerals along certain layers parallel to foliation. Injection apparently had little influence on the formation of these layered rocks.

The relative abundance of the different minerals in incompletely transformed rocks indicates that most quartz was introduced early in the transformation, before significant quantities of microcline were introduced. The later stages of metasome,tic alteration generally show only a slight increase in quartz, but considerable recrystallization apparently took place as it is difficult to determine any consistent age relationship for quartz and microcline in thoroughly transformed rocks. Quartz typically is in lobate to rounded blebs and grains and as elongated crystals and aggregates strung out along the foliation. It defir itely corrodes and replaces plagioclase and biotite, and some crystallized late in the transformation and c'its microcline as well.

Small ragged flakes and grains of biotite are scattered through the quartz monzonite gneiss. The biotite is corroded by microcline and quartz and commonly is associated with abundant dusty to granular magnetite and hematite. In places muscovite is interleaved with biotite or forms discrete flakes. Many of the rocks contain secondary chlorite and magnetite associated with biotite.

Chlorite is most common in the rocks in which early albitization was intense. It is especiall' abundant in partly transformed rocks, where it forms pseudomorphs after hornblende; but where transformation was more complete, chlorite rarely makes up more than a few percent of the rock and generally is in ragged shreds with abundant dusty to granular magnetite and 
hematite. Sphene and epidote are associated with some of the chlorite and are most abundant in incompletely transformed rocks (pl. $50 \mathrm{D}$ ).

Irregular small grains and aggregates of magnetite and hematite are distributed through most quartz monzonite gneiss. They are commonly associated with corroded biotite and chlorite grains and appear to be most abundant where replacement was most complete; it is likely that most of the scattered grains are residual from the replacement of original ferromagnesian minerals in the rock.

Pink garnet is relatively abundant in some of the smaller bodies of quartz monzonite gneiss. It has the same appearance and index of refraction as garnet found in partly altered metamorphic rock and pegmatite; in all probability it is a residual mineral that survived transformation. Zircon and apatite occur as very minor accessory minerals.

\section{ORIGIN}

Quartz monzonite gneiss in the Northgate district formed through reaction between hornblende gneiss and silica- and alkali-bearing solutions which permeated the rock after dynamothermal metamorphism. Quartz monzonite gneiss is in extremely irregular bodies that do not conform to the highly folded structure of the hornblende gneiss. Although some local control on replacement was exerted by folds in the host rock, almost all medium- to large-sized masses transgress the older structures. In spite of the occurrence of the quartz monzonite gneiss in crosscutting bodies the adjacent rocks show no deformation, and the orientation of foliation in numerous inclusions of hornblende gneiss within quartz monzonite gneiss is parallel to that of the enclosing rock and of the adjacent hornblende gneiss. Even in local areas where bodies of quartz monzonite gneiss conform in part to folds in the hornblende gneiss, the quartz monzonite gneiss shows the same textural evidence for a replacement origin as was noted elsewhere, and the relations are those of incompletely replaced folded rocks rather than of folded granitoid rocks or phacolithic intrusion.

Intermediate stages in the transformation of hornblende gneiss to quartz monzonite gneiss are found throughout the district. Gradational contacts are common along their strike of foliation, and many small bodies of quartz monzonite gneiss show all stages of the transformation. Although marginal transition zones are not conclusive evidence as to the origin of the interiors of such bodies, the presence of relict textures and masses of incompletely replaced rock within large bodies of quartz monzonite gneiss indicates that all of the quartz monzonite gneiss is of replacement origin.
Petrographic study of intermediate stages in the formation of quartz monzonite gneiss indicates that most plagioclase is pseudomorphous after the plagioclase in the original hornblende gneiss, and that replacement by quartz and microcline began along grain boundaries and gradually engulfed the adjacent crystals. Hornblende was converted to biotite or chlorite, and the ferromagnesian content decreased as the transformation progressed. Even though most hornblende gneiss is poorly foliated, the foliation apparently exercised considerable control on the flow of the hydrothermal solutions and thus in turn controlled the layered character of quartz monzonite gneiss. Contacts of quartz monzonite gneiss bodies are commonly sharp across the trend of foliation.

Thus field and petrographic evidence indicates that transformation was accomplished by tenuous solutions that were capable of penetrating large masses of rock without disturbing the structural continuity of that rock. Lime, magnesia, and iron were largely replaced by potash, soda, and silica. Early conversion of hornblende to biotite and the introduction of quartz, followed by the formation of microcline and more quartz in most of the quartz monzonite gneiss, indicate that potash and silica were important constituents of the solutions. - Albitization was not intense in mo $t$ of these rocks, and the plagioclase most commonly is sodic oligoclase. This fact suggests that the soda concentration of most of the solutions was relatively low.

Local transformation of hornblende gneiss to albitechlorite-quartz rocks without a significant decrease in plagioclase content followed by later formation of microcline and more quartz, indicates that locally the early solutions were soda rich but that they became more potassic as transformation progressed. These albitic rocks occur throughout the gneiss complex, even in the interiors of large bodies of quartz monzonite gneiss. No control for this type of alteration was discerned in the field; such alteration, however, is particularly abundant in many relatively small bodies of quartz monzonite gneiss. It is suggested that the sodic alteration may have been a local marginal effect of solutions enriched in soda by potash metasomatism of plagioclase feldspars at depth. As granitization progressed, sodic alteration was followed by potash metasomatism.

\section{BIOTITE-GARNET GNHISS} GENERAL FEATURES AND DISTRIBUTTON

Irregular bodies of biotite-garnet gneiss (biotitegarnet-quartz-plagioclase gneiss) occur in the central part of the Northgate district, where they are associated with abundant pegmatite, and in the southeastern part, 
associated with quartz monzonite gneiss and minor amounts of pegmatite. The largest bodies of biotitegarnet gneiss are near the lower reaches of Camp Creek and the North Platte River, where several connected masses 1,000 to 6,000 feet long and 500 to 1,500 feet wide crop out (pl. 48). Many smaller bodies are found here and elsewhere throughout the area where pegmatite is abundant; many are too small to be shown on the geologic map (pl. 48).

The scattered masses of biotite-garnet gneiss are closely associated with pegmatite, and show all gradations from hornblende gneiss to pegmatite. The gradation into pegmatite is through transitional zones either of lit-par-lit gneiss or by a general coarsening of grain and decrease in biotite content. The bodies of biotitegarnet gneiss are so discontinuous and haphazardly distributed, and the contacts are so indistinct and irregular, that it seems very probable that the rock originated through transformation of hornblende gneiss. This interpretation is supported by the many untransformed or partly transformed relicts of hornblende gneiss commonly found within bodies of biotite-garnet gneiss.

Biotite-garnet gneiss ranges from slightly garnetized hornblende gneiss to coarsely porphyroblastic augengneiss, banded lit-par-lit gneiss, and even pegmatite. Variable grain size and uneven texture characterize the interior of most bodies of biotite-garnet gneiss. In most biotite-garnet gneiss the different minerals tend to be distributed unevenly, and the degree of mineral segregation increases with increase in garnet, quartz, and biotite. Layering is conspicuous in some rocks, and quartz and feldspar form discontinuous thin layers and lenses interleaved with layers rich in biotite. Red garnet is irregularly distributed through most of the rock. It is most abundant in or near quartz-feldspar layers; elsewhere the garnet aggregates are commonly surrounded by light-colored halos that are poor in biotite. Where layering is not conspicuous, quartz and plagioclase with minor amounts of biotite form irregular or lenticular aggregates in biotite-rich gneiss. Such biotite-rich and biotite-poor masses of rock intergrade completely and commonly form masses a few inches to a few feet in diameter.

The transition zones between hornblende gneiss and biotite-garnet gneiss are commonly narrow and are marked by the appearance and progressive increase in abundance of biotite and quartz. Red garnet may occur in some of the transition zones, but generally it is more abundant in the more altered rock. With increasing quantities of biotite, the foliation becomes more marked, but in general the rock in the transitional zones strongly resembles hornblende gneiss. Within a few inches in from the margins, hornblende becomes rare, and biotite, quartz, and plagioc' ase crystals generally are coarser than the grains in the original rock. In local facies some even-grained aggregates of plagioclase, quartz, and biotite with minor amounts of garnet and scattered relicts of hornblende make up fairly large bodies, but more commonly such aggregates form only small bodies near the margins of more typical biotite-garnet gneiss.

Near the large pegmatite bodies, the gneiss is extremely variable and the quartz-feldspar layers pass into small pods and stringers of relatively fine-grained quartz-plagioclase-garnet pegmatite. Feldspar augen or small pegmatitic knots of quartz, plagioclase, and garnet occur singly or in beadlike strin $;$ s along the foliation; in places these knots coalesce into fairly persistent bands several inches thick, or into irregular masses a few inches to a few feet in diameter. With increasing numbers of pegmatitic pods $\varepsilon$ nd stringers, the gneiss attains a typical lit-par-lit structure; many have a distinctly knotted appearance in outcrop. As the quantity of associated pegmatite increases, the biotite-rich bands become thinner and more discontinuous; and microcline, hitherto a minor constituent, becomes progressively more abundant. It ll gradations exist between the lit-par-lit variety of biotite-garnet gneiss and many of the larger, microcline-rich pegmatite bodies.

\section{PETROGRAPHY}

The texture of the biotite-garnet gneiss along its margins greatly resembles that in the surrounding hornblende gneiss (pl. 52A). Hornblende and plagioclase grains closely resemble in size, shape, and composition such grains in hornblende gneiss and apparently are relict. Biotite occurs along the cleavage and grain margins of hornblende and as separate flekes. Where not strung out along later shear zones, bitite tends to be distributed evenly through the gneiss and is oriented nearly parallel to the layering; the rock is distinctly better foliated than the original hornk ${ }^{-}$ende gneiss. Irregular to lobate quartz grains have replacement relations toward the other minerals. A representative specimen of this rock is made up of abo'tt 40 percent plagioclase $\left(\mathrm{An}_{28-35}\right), 30$ percent quartz: 15 percent hornblende, and 15 percent biotite. As much as 5 percent microcline is found in some rceks near the margin. Hornblende is absent or is ver" subordinate to biotite a short distance from the contact, and the quartz here is somewhat coarser and more abundant than along the margins.

The minerals in most of the biotite-garnet gneiss are unevenly distributed, and the texture shows wide variation. In banded varieties the quartz-plagioclase layers are discontinuous and have very indistinct 
margins. Commonly they coalesce into irregular masses with pegmatitic texture. The darker biotiterich layers generally are somewhat finer grained than the light-colored layers and are thickest and most abundant where associated pegmatite is sparse. Garnet, with associated quartz, biotite, and blue amphibole, forms irregular to rounded aggregates many of which are as much as half an inch, and more rarely several inches, in diameter. Most garnet aggregates are in the quartz-feldspar layers or are surrounded by lightcolored halos poor in biotite, but locally garnet occurs in nests of coarse biotite. The mineral composition of these different "typical" biotite-garnet rocks varies greatly, but most of these rocks consist of about 40 to 45 percent plagioclase, 25 to 35 percent quartz, 15 to 20 percent biotite, and as much as 15 percent garnet. Relict hornblende in minor amounts is widespread, and several percent of microcline occurs in some specimens.

Some quartz-plagioclase-garnet stringers have a typical pegmatitic texture in which some quartz and feldspar crystals are an inch or more in diameter and associated biotite and garnet are only a little less coarse. The texture of the rock adjoining the pegmatitic stringers is locally very similar to the more normal biotite-garnet gneiss, but commonly it is even more irregular.

Much of the biotite-garnet gneiss and related rocks underwent minor granulation during the period of shearing that elsewhere formed hornblende-biotite gneiss and mylonite gneiss. Quartz stringers and relatively coarse, undeformed biotite follow some granulated zones through these rocks, and both quartz and biotite, as well as plagioclase, are ground up and spread out along others. Thus the shearing appears to have taken place at about the same time as the transformation.

The composition of plagioclase in biotite-garnet gneiss is remarkably uniform and is generally between $\mathrm{An}_{28}$ and $\mathrm{An}_{35}$. A striking feature is that within any given body, the plagioclase has the same composition whether it occurs as relict crystals in the narrow, hornblende-bearing marginal zones, as relict or recrystallized grains in the main part of the body, or as coarse and completelv recrystallized grains in the quartz-plagioclase-garnet pegmatite stringers. In several suites of specimens from different biotite-garnet gneiss bodies the range in composition of plagioclase was only 3 or 4 percent of anorthite (close to the limit of accuracy of determination), and the range in individual specimens was nearly as great. The only general variation noted in plagioclase composition is in those pegmatitic rocks containing 10 percent or more of mi rocline; in these the plagioclase composition generally is near $\mathrm{An}_{25}$.

One local and significant deviation in plagioclase $402890-57-3$ composition was noted in a specimen of slightly altered hornblende gneiss from the margin of a relatively small body of biotite-garnet gneiss. Most of the specimen is made up of about 45 percent hornblende, 40 parcent plagioclase, 10 percent quartz, and 5 percent k intite. Plagioclase and hornblende have the same textural relationship of these minerals in normal hornblende gneiss, quartz corrodes the plagioclase and hornt 'ende, and biotite occurs along cleavage planes and marrins of hornblende. An irregular stringer of about one-eighth inch thick of biotite-garnet-plagioclase rock follows along the foliation of this slightly altered hornblende gneiss. This stringer of typical biotite-garnet gneiss, which contains a few ragged hornblende relict only partly altered to biotite, grades into the adjacent hornblende gneiss. The composition of 15 plagioclase grains was determined by measuring extinction angles on grains of known orientation; five grains from the relatively unaltered hornblende gneiss have an average composition of $\mathrm{An}_{30}$, five grains from the margins of the biotite-garnet gneiss stringer range from $A_{35}$ tc $A n_{37}$, and five grains from the central part of the stringer range

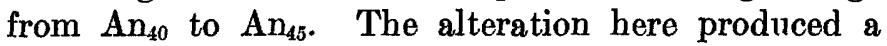
distinctly more calcic plagioclase than that in the original rock.

Plagioclase grains have the same general sirg and shape in the marginal transition zones and in the evengrained varieties of biotite-garnet gneiss as in tl ? surrounding hornblende gneiss. In more uneven-textured biotite-garnet gneiss, however, the plagioclase ranges widely in grain size and was largely recrystallized. The large recrystallized grains in the quartz-plagioclasegarnet pegmatite stringers generally embay smaller plagioclase grains. As most of the crystals are clear, the change in composition was not due to a saussuritic breakdown of the original plagioclase.

Plagioclase makes up 40 to 50 percent of most biotite-garnet gneiss, regardless of grain size or texture. This is only slightly less than the average amount in hornblende gneiss. Only in pegmatitic varieties of biotite-garnet gneiss does the quantity of plagioclase vary significantly; plagioclase commonly makes up $\mathbf{5 0}$ to 70 percent of the quartz-plagioclase-garnet st.ingers and pods, and it is relatively minor where abundant microcline is present.

Hornblende is most abundant in the transitior zones between hornblende gneiss and biotite-garnet gneiss, where it occurs in irregular grains that commonly are partly altered to biotite (pl, 52 A). Where biotite is subordinate, the hornblende is similar to that in adjacent, unaltered hornblende gneiss; as the quantity of biotite increases, the hornblende relicts become smaller, less abundant, and much more irregular. Hornblende in the typical biotite-garnet gneiss is in scattered, ragged 
grains, which are generally associated with abundant biotite. Hornblende generally is absent in the biotitegarnet gneiss near pegmatite and quartz monzonite gneiss. Some of the pegmatitic pods, however, contain hornblende crystals one-half inch or more long, and apparently the adjacent rock was considerably enriched in hornblende.

Biotite is closely associated with abundant hornblende in the marginal transition zones and in partly transformed hornblende-rich inclusions within biotitegarnet gneiss bodies. Biotite is regularly distributed through the relatively even grained biotite-garnet gneiss. The relationship with scattered hornblende relicts indicates that the biotite here is in part at least an alteration product of hornblende. Where transformation was more complete, most biotite is in separate grains that show no trace of their origin, but all relict hornblende crystals have some closely associated biotite. In the uneven-textured, thoroughly recrystallized rocks, biotite forms irregular concentrations and stringers that vary widely in grain size. Biotite is coarsest where it is most abundant, and in some rocks it forms local concentrations with grains one-half inch or more in diameter. More commonly it is mixed with variable announts of plagioclase and quartz or is closely associated with garnet aggregates. Coarse-grained biotite is a minor constituent of many pegmatite pods and stringers.

The biotite in all these occurrences has essentially the same optical properties, and presumably has essentially the same chemical composition. The pleochroic colors are yellow and dark brown, and the $2 \mathrm{~V}$ is small, in many thin sections being sensibly zero. The higher index of refraction ( $\beta$ essentially equals $\gamma$ ) was measured for 6 specimens representative of all degrees of transformation; 4 of these measurements were between 1.65 and 1.66, 1 was between 1.64 and 1.65 , and another was slightly above 1.66. These properties are characteristic of ordinary biotite, and no evidence was seen for either markedly magnesian or markedly ferriferous biotite.

The total hornblende and biotite content generally decreases from the marginal transition gneiss to the lit-par-lit gneiss and pegmatitic gneiss. Hornblende comprises 35 percent or more of most hornblende gneiss, and in the margmal parts of biotite-garnet gneiss bodies combined hornblende and biotite unake up 25 to 35 percent of the rock. Biotite generally makes up only 15 to 25 percent of those rocks where hornblende is minor or absent, and as little as 5 percent of much lit-par-lit gneiss and rock cut by abundant pegmatite.

Red garnet is widely but irregularly distributed through biotite-garnet gneiss and associated pegmatite, and locally it also occurs in the adjacent hornblende gneiss near a contact with pegmatite or biotite-garnet gneiss. Garnet is coarsest and most ak'undant near pegmatite bodies and in many places is found only in thin peripheral zones around pegmatite. In other places, garnets are distributed throughout relatively large masses of biotite-garnet gneiss. Rock with abundant garnet generally has less biotite than similar rock with less garnet. The garnets ar? completely isotropic and probably belong to the almandinepyrope group. The index of refraction of garnets in 26 specimens from all occurrences was determined. In 24 specimens the index was between 1.79 and 1.80 , and in 2 specimens the index was significantly above 1.80. Thus the composition of most garnets in biotitegarnet gneiss and related rocks probably is near $\mathrm{Al}_{70}-\mathrm{Py}_{30}$. The garnet typically occurs as granular, poikiloblastic aggregates with abundant rounded quartz inclusions and variable amounts of closely associated blue amphibole and biotite.

All stages in the formation of garnet were seen, and it apparently formed from materials derived from the breakdown of both hornblende and biotite. In the earliest stages, garnet formed in scattered, irregular to rounded spots as much as one-half inch in diameter consisting of small grains of blue amphibole and biotite with a few small garnet granules set in a fine mosaic of quartz and sericitized plagioclase (pl. $52 \mathrm{R}$ ). Adjacent hornblende and biotite generally are scmewhat corroded. As the quantity of garnet increases, the quantity of blue amphibole, biotite, and plagioclase decreases, and the quartz aggregates into rounded blebs surrounded by or closely associated with granular garnet (pl. 52 C). The larger garnets are in rounded to very irregular aggregates with abundant lobate to rounded quartz inclusions and variable quantities of closely associated biotite (pl. $52 C$ ). The biotite occurs in peripheral concentrations, scattered inclusions, and fracture fillings; some relatively large crerstals project haphazardly into or through the garnet. Small grains of blue amphibole are associated with many garnet aggregates but generally are absent where biotite is abundant. The garnets within biotite concentrations are surrounded by thin rims of fine quartz, sericitized plagioclase, and biotite, and the larger adiacent biotite crystals are strongly corroded (pl. $52 \mathrm{D}, \mathrm{E}$ ).

The blue amphibole associated with many garnet aggregates is most abundant where the surrounding rock is rich in hornblende, but it is relatively common even where the hornblende. in the adjacent gneiss is insignificant in amount (pl. $52 B, E, F$ ).

Most of the blue amphibole is in small, irregular to idioblastic grains that formed as an intermediate step in the development of garnet, but in soma hornblende- 
rich rocks the original hornblende crystals adjacent to the garnet aggregates were partly or entirely converted to blue amphibole. The pleochroic colors of the blue amphibole are yellow, blue green, and green blue in contrast with the yellow, grass green, and dark green of unaltered hornblende in hornblende gneiss.

Although biotite is a common associate of garnet, the rock around the larger garnet aggregates commonly is relatively poor in biotite and hornblende, and in places the minerals in these light-colored halos are distinctly coarser grained than those in the rest of the rock. The biotite-poor halos that surround garnet aggregates and the relatively low percentage of biotite and hornblende in those rocks where garnet is abundant indicate that most of the garnet-forming material was locally derived from the biotite and hornblende. Total biotite and garnet, however, rarely exceeds 25 percent of typical biotite-garnet gneiss and generally is less than 20 percent; consequently these totals represent a significant decrease in the iron and magnesia held in the original hornblende gneiss.

The quantity of quartz in biotite-garnet gneiss varies widely, but generally it makes up 20 to 40 percent of the rock. Even in marginal zones it comprises as much as 30 percent of some biotite-garnet gneiss. It forms small lobate grains in slightly altered rocks; with increasing alteration the quartz became coarser, more irregular, and somewhat more abundant.

Microcline in wisps and small grains constitutes as much as 5 percent of some typical biotite-garnet gneiss (pl. $52 C$ ), but in much of the rock it is absent. Some biotite-garnet gneiss, particularly near large microclinebearing pegmatite bodies, contains 30 percent or more of microcline in grains that range from very small wisps to almost rectangular augen an inch or more in length. Myrmekite is widespread in these rocks, and many microcline cyrstals are crowded with unreplaced inclusions of plagioclase, biotite, and quartz. Some of these inclusions are aggregates that show the normal relationship of biotite-garnet gneiss; microcline, therefore, was evidently the last mineral formed in the biotite-garnet gneiss.

Accessory minerals in original hornblende gneiss make up only a fraction of a percent of the rock; apatite is the most abundant of these, but sphene is also widespread. Both apatite and sphene, as well as variable amounts of secondary epidote, are much more abundant in the biotite-garnet gneiss, and appear to become more abundant with an increase of garnet and microcline. Zircon and magnetite also are fairly common in biotite-garnet gneiss, but they are greatly subordinate to apatite, sphene, and epidote.

\section{ORIGIN}

Abundant evidence indicates that biotite-garnet gneiss originated by transformation of hornblende gneiss. Contacts between these two rock types are gradational and irregular; many untransformed or incompletely transformed remnants of hormblende gneiss occur throughout the biotite-garnet gneiss; and many details of the transformation can be observed under the microscope. The close association with pegmatite and minor amounts of related quartz monzonite gneiss and the evidence for resurrent shearing during transformation indicate that the transformation was a phase of the general dynamic and metasomatic metamorphism that affected the gneiss complex during the later stages of regional metamorphism.

Except for the relatively late introduction of microcline (changes more closely related to the origin of microcline-rich pegmatite discussed in the following section), the transformations produced chiefly minerals containing considerable lime, magnesia, and iron, and introduced abundant silica. Normal hornblende gneiss, having roughly equal proportions of intermediate plagioclase $\left(\mathrm{An}_{30-55}\right)$ and hornblende, was converted to a rock composed of biotite, garnet, quart 3 , and plagioclase $\left(\mathrm{An}_{28-35}\right)$. Total ferromagnesian content shows a slight but progressive decrease with increased alteration.

To accomplish these changes, silica for the quartz was needed in excess of the few percent which may have been derived from the breakdown of hornblende to biotite and garnet, as the quantity of quartz in most biotite-garnet gneiss exceeds that of the combined biotite and garnet and is about the same as that of hornblende in the original rock. Some potssh, in addition to that already present in the amphibo'e, may have been required to permit the formation of biotite from hornblende. Potash concentration in the early stages was apparently low, however, for little microcline was formed then. The other alterations required removal of small amounts of lime, magnesia, and iron. These changes contrast notably with those in the adjacent zones where quartz monzonite gneiss was formed. Large quantities of lime, magnesia, and iron were replaced by alkalies and silica as the interneediate plagioclase of the hornblende gneiss was converted to sodic oligoclase or albite and the ferromagnesian minerals were largely destroyed.

Although under classical theories of metamonphism the minerals of the biotite-garnet gneiss are generally considered to originate at higher temperatures than those in quartz monzonite gneiss, geologic evidence here 
indicates that this was not the case. Biotite-garnet gneiss occurs with abundant pegmatite in a zone approximately peripheral to the large quartz monzonite gneiss bodies, a zone where the temperature should have been somewhat lower.

More probably the differences in reaction were related to differences in concentration of the materials in solution. Yoder $(1952$, p. 615-617) has shown that the same mineral assemblages can form under widely different temperature and pressure conditions, depending on the bulk composition of a system. Evidently most alkalies in the solutions were precipitated in the formation of quartz monzonite gneiss, a precipitation Wegmann $(1935$, p. 326$)$ postulates as taking place within a narrow zone or "front." As the solutions migrated outward and were impoverished in alkalies they undoubtedly were enriched in displaced lime, magnesia, and iron. Thus the alteration of the rock above the granitization "front" would take place in an environment relatively low in alkalies and rich in lime, magnesia, and iron. There was no precipitation of these materials in the biotite-garnet gneiss to form a "basic front" (Reynolds, 1944, p. 235-238; Read, 1948, p. 11-12); rather there is evidence for slight removal. However, the uniformity of composition of plagioclase and garnet indicates that these minerals formed by reaction with solutions considerably richer in lime, magnesia, and iron than those in deeper zones.

Although progressive mineralogic and textural changes clearly indicate the replacement origim of most biotite-garnet gneiss, the origm of quartz-plagioclasegarnet pegmatite is not so obvious. Bodies of this rock range from small knots a few inches in diameter through thin discontinuous stringers in lit-par-lit gneiss to relatively persistent, veinlike bodies a few inches thick and as much as several tens of feet long and irregular masses up to several feet or more in diameter. Because of their coarse grain and low biotite content these rocks are distinctive; but the bodies do not displace their walls, and the contacts characteristically are gradational. Although present in different proportions, the minerals are the same as those in the wall rocks; and neither plagioclase nor garnet shows any change in composition across the contacts of the pegmatitic bodies. Evidently the quartz-plagioclase-garnet pegmatite resulted from the same alteration that produced the adjacent biotitegarnet gneiss.

\section{PEGMATITE}

GENERAL FEATURES AND DISTRIBUTION

Quartz-microcline-plagioclase pegmatite is abundant in a zone in the central part of the Northgate district, between the large masses of quartz monronite gneiss in the northern and southeastern parts of the district. Associated with the abundant pegmatite are small bodies of quartz monzonite gneiss, but they are largest and most abundant to the north, where tro pegmatite and quartz monzonite gneiss zones orerlap. The largest pegmatite bodies are in the west-central part of the district where some very irregular masses are more than 2 miles long and 2,000 feet wide. Biotitegarnet gneiss is associated with the abundant pegmatite through the central part of the pegmatite zone, where quartz monzonite gneiss is subordinate. In the southern part of the pegmatite zone where relations have been greatly obscured by later igneous intrusion, Laramide faulting, and Tertiary alluviation, pegmatite appears to be much less abundant than farther north. It forms many small bodies on Pinkham Mountain and eastward where shearing appears to have been active during the period of metasomatism that followed dynamothermal metamorphism (see "Lithology" following). The southern margin of the pegmatite zone coincides with an irregular belt of mylnnite gneiss near Pinkham Creek. Some pegmatite is associated with the large masses of quartz monzonite gneiss both north and south of the pegmatite zone, but is less abundant here than in the central part of the district.

Although some of the smaller pegmatite lenses bulge the foliation and layering in their wall rocks and apparently represent injected material, most of the larger bodies show replacement relations toward the host rock. Rocks surrounding the ramifying pegmatite masses are not displaced or deformed, and the foliation in the wall rock and in numerous undigested inclusions of country rock in pegmatite shows the sime orientation. In some places contacts of pegmatite bodies are sharp, but elsewhere pegmatite grades into such diverse rocks as hornblende gneiss, hornblende-biotite gneiss, biotite-garnet gneiss, and quartz monzonite gneiss. Locally many smaller bodies range from quartz monzonite gneiss in one part to pegmatite in another. Pegmatite and quartz monzonite gneiss generally appear contemporaneous, but where an $\varepsilon \approx e$ sequence can be determined pegmatite is always the younger.

\section{LTTHOLOGY}

With few exceptions, pegmatite in the Northgate district shows little mineralogic zoning, but is a simple aggregate of quartz and feldspar with subordinate muscovite, biotite, garnet, and magnetite or hematite. The texture characteristically is uneven, and some grains are as much as several inches in diameter. Very coarse pegmatite is rare. Many pegmatite bodies have a distinct megascopic foliation shown by abundant 
elongate quartz aggregates, or, more rarely, by muscovite-covered folia.

The pegmatite ranges widely in composition from plagioclase rich, microcline poor through all gradations to those in which nearly all the feldspar is microcline. Where plagioclase is abundant the rock generally is white to gray and is relatively fine grained for pegmatite. Microcline occurs in scattered pink crystals, and garnet and biotite are most abundant in these rocks. Where microcline is more abundant, the rock is distinctly pink and generally coarser grained. In microclinerich pegmatite, plagioclase is in scattered grains and in irregular granular aggregates. In places quartz and the associated feldspar show the same range in grain size, but more commonly the quartz is in irregular aggregates between larger feldspar grains. Muscovite is abundant in a few bodies, but is very scarce or absent in most. Magnetite, or hematitic and limonitic pseudomorphs after magnetite, is widespread in the pegmatite, and in places makes up several percent of the rock.

Most contacts of pegmatite with quartz monzonite gneiss and biotite-garnet gneiss are completely gradational. In quartz monzonite gneiss the pegmatite occurs either as narrow bands parallel to foliation or as irregular masses of various shapes and sizes. Biotitegarnet gneiss grades into microcline-rich pegmatite through an abrupt increase in microcline, a decrease in biotite, and a general increase in grain size. The change is most abrupt in the medium-grained eventextured biotite-garnet gneiss, whereas in the lit-par-lit variety, where much of the adjacent rock has a pegmatitic or near pegmatitic texture, the transition more commonly is gradational.

The relations between pegmatite and hornblende gneiss are considerably more varied. Some contacts are sharp but more commonly a narrow, epidote-rich transition zone exists between the two rocks. Chlorite, pink plagioclase (albite), garnet, and specularite are common associates of epidote in the transition zone; microcline is progressively more abundant toward the center of the pegmatite. The transition zone is highly variable in texture and ranges from pseudomorphic hornblende gneiss through structureless aggregates to distinctly pegmatitic textures.

Quartz was widely leached from some pegmatite bodies and locally some quartz monzonite gneiss bodies as well. The leached rock comprises a cellular feldspar skeleton of the original rock. Many of the cavities contain scattered to numerous flakes of specular hematite and a few of the holes are lined with small, euhedral quartz crystals. Most of the masses of leached rock are only a few feet or tens of feet in diameter and make up only a small part of the affected bodies. The leaching was erratically distributed, and except for a slight tendency toward localization near the bulbous ends of pegmatite bodies, no structural control was discerned. In some places numerous partly leached relicts occur through the more cellular rock.

\section{PFTROGRAPHY}

The relative abundance of the different minemals in the pegmatite varies widely from quartz-plagioclasegarnet pegmatite with subordinate microcline to auartzmicrocline pegmatite with little or no plagioclise or garnet. Quartz makes up 20 to 30 percent of almost all the pegmatite, and in most of the rock microcline is significantly more abundant than plagioclase. Garnet, generally with some associated biotite, is relrtively abundant in those rocks where plagioclase is abundant, but it is rare and irregularly distributed in microclinequartz pegmatite. Muscovite is abundant in a few places but generally is rare. Minor quantitios of magnetite are widespread.

Plagioclase generally occurs in irregularly shaped aggregates with quartz, and rocks where plagioclase is the most abundant feldspar are finer grained than the more common, microcline-rich pegmatite.

Plagioclase was one of the earliest minerals in the pegmatite to crystallize, and most of it is corroded and partly replaced by microcline and quartz. In those bodies where plagioclase makes up more than a few percent of the rock its composition generally ranges from $A_{20}$ to $A_{30}$. Where plagioclase is a minor constituent of the pegmatite, it tends to be distinctly more sodic and ranges from $A_{10}$ to $A_{15}$. Some grains are clear but most are somewhat sa ussuritized; a few grains are heavily crowded with saus ${ }^{\circ}$ uritic and sericitic inclusions. Little correlation exists between composition and degree of alteration. Myrmekitic borders are common on plagioclase grains where considerable replacement by microcline has taken place.

Microcline ranges from small crystals between the plagioclase grains to large, irregular to almost rec ${ }^{\dagger}$ angular crystals, many of which contain abundant corroded inclusions of plagioclase. Commonly several adjacent inclusions have the same optical orientation. In plagioclase-rich pegmatite, the microcline apparently formed in a previously existing rock, and all degrees of replacement can be seen from these early rocks to rocks in which the feldspar is largely microcline.

Quartz occurs in irregular to lobate grains and aggregates that are unevenly distributed through the rock. Where plagioclase is abundant the associated auartz appears to be about contemporaneous, but where microcline is the predominant feldspar much of the auartz is corrosive toward the plagioclase and appears to be of about the same age as the microcline. As quertz in 
the plagioclase-rich pegmatite and in the microclinerich pegmatite is about equally abundant, the apparent difference in relative age may be due in large part to recrystallization of quartz already present. This recrystallization is further indicated by a general increase in grain size of quartz with an increase in microcline content.

In those pegmatite bodies that show a megascopic foliation, the elongated quartz aggregates appear under the microscope as stringers and veinlets along recrystallized cataclastic zones. Granulated feldspar and quartz along these zones have recrystallized to a fine interlocking aggregate of irregular grains, and are cut by the larger quartz stringers which definitely occur later than the shearing. Where present, muscovite forms small grains in the recrystallized cataclastic aggregate and larger flakes and layers associated with the late quartz stringers. Both varieties crystallized after shearing.

Garnet has about the same index of refraction in pegmatite as it has in the adjacent biotite-garnet gneiss. The irregular to rounded grains and aggregates have a typical sieve texture, with abundant blebby quartz inclusions and variable quantities of closely associated biotite. Garnet is most abundant and the associated biotite is most common in pegmatite that is rich in plagioclase; garnet is relatively minor and biotite is absent in pegmatite where replacement by microcline was more complete. The garnet grains appear to have been inherited in large part from an earlier stage in the transformation and replacement of hornblende gneiss.

The contacts between pegmatite and hornblende gneiss are marked in many places by abundant epidote and lesser quantities of chlorite and albite. Some of these rocks show good relict texture of the original hornblende gneiss, with chlorite pseudomorphs of hornblende set in a dense matrix of epidote. More commonly the alteration product is a dense green rock composed of predominant granular to prismatic epidote with variable quantities of pink albite $\left(\mathrm{An}_{2-5}\right)$. Sphene, chlorite, and hematite are common accessory minerals. In places the epidote-albite rock is coarse grained and has a pegmatitic texture. Garnet is fairly common in hornblende gneiss near pegmatite and in the transition zones, and in one place a dense garnet-clinozoisitescapolite-albite-sphene rock occurs along a pegmatitehornblende gneiss contact.

\section{ORIGIN}

Pegmatite and quartz monzonite gneiss are commonly closely associated in the Northgate district and field and petrographic data suggest that they both originated through metasomatism. The large pegmatite bodies are extremely irregular and contain numerous inclusions of metamorphic rocks. With few exceptions the wall rocks and inclusions show no evidence of deformation, and the foliation in the inclusions and the wall rocks generally has the same orientation. Many of the contacts are gradational. Some of the smaller pegmatite bodies clearly displace their walls, but most of the pegmatite in the larger masses evidently replaced rather than intruded the metamorphic rocks. This conclusion is further suggested by the progressive replacement of plagioclase by microcline as well as the occurrence of apparently relict plagioclase with relatively calcic composition $\left(\mathrm{An}_{20-30}\right)$ and garnet even where microcline is relatively abundant.

Microcline in all the pegmatite, even in the central part of large pegmatite bodies is corrosive toward plagioclase, and in marginal zones betwe m pegmatite and biotite-garnet gneiss, microcline clearly formed after the biotite-garnet gneiss was formed. These same relations are found in the gradational contacts of biotite-garnet gneiss inclusions within pegmatite as well. The composition of most plagioclase in the pegmatite in the Northgate district is more calcic $\left(\mathrm{An}_{20-30}\right)$ than is common in quartz-feldspar pegmatite, and garnet in the pegmatite has about the same composition as garnet in adjacent biotite-garnet gneiss. Apparently both the plagioclase and garnet are relict.

Although a distinct sequence in time between biotitegarnet gneiss and pegmatite is implied by the late introduction of microcline, it seems likely that the two rocks were formed about contemporaneously, but that the biotite-garnet gneiss formed ahead of $\varepsilon n$ advancing pegmatite "front." This hypothesis is consistent with the common close association of pegmatite with the more thoroughly transformed biotite-garnet gneiss and the apparently continuous local sequence in time between the two rocks. Although commonly closely associated, biotite-garnet gneiss and pegrr atite bear no constant relation to each other in space. Piotite-garnet gneiss generally is most completely tran fơrmed near large pegmatite bodies, but many thoroughly transformed masses of biotite-garnet gneiss hrve relatively little closely associated pegmatite, and many pegmatite bodies have no associated biotite-garnet gneiss. No unequivocal example of concentric zoning of biotitegarnet gneiss around a large mass of pagmatite was observed, and in many places a pegmatite body grades into highly altered biotite-garnet gneiss on one side and into hornblende gneiss on the other. Transforming solutions at a given locality apparently changed with the advance of the pegmatite "front" from those that caused the formation of biotite-garnet gneiss (relatively rich in lime, magnesia, and iron) to those that caused the formation of pegmatite (ricl in potash). Where the later solutions followed the same general 
channels as the earlier solutions, biotite-garnet gneiss and pegmatite are closely associated; where new channels formed or old channels shifted during transformation, the alteration products occur either alone or with minor intermixing.

\section{HORNBLENDE-BIOTITE GNEISS}

GENERAL FEATURES AND DISTRIBUTION

Hornbleńde-biotite gneiss includes a group of wellfoliated rocks made up of varying proportions of hornblende, biotite, quartz, and plagioclase. Small amounts of microcline are widespread, but erratically distributed. The rocks form a complexly interlayered series that range from unaltered hornblende gneiss to fine-grained mylonite gneiss, and petrographic evidence indicates that the present textures and mineral composition are related to the degree of shearing and recrystallization the different rocks were subjected to subsequent to dynamothermal metamorphism. Foliation in the hornblende-biotite gneiss is parallel to the layering in adjacent hornblende gneiss, and the different rocks appear to be interbedded. The mixed rocks do not persist along the strike; the layers feather out and grade into hornblende gneiss. The hornblende-biotite gneiss is erratically distributed, and it is not separated from hornblende gneiss on the geologic map (pl. 48).

These rocks are most abundant on the southern part of Pinkham Mountain and along Pinkham Creek, where they are associated with mylonite gneiss. Some hornblende-biotite gneiss occurs south of the belt of mylonite gneiss, but relations are obscured by large masses of quartz monzonite gneiss and by Laramide faulting. Farther north, hornblende-biotite gneiss alternates with larger and larger masses of normal hornblende gneiss. No hornblende-biotite gneiss was seen in the northern and northwestern parts of the district.

\section{LITHOLOGY}

Hornblende-biotite gneiss varies widely in mineral composition and texture from place to place as it is made up of a completely gradational series of rocks. The foliation generally is more distinct than in hornblende gneiss. Where hornblende is abundant the rock has a grain size about comparable with that in the associated hornblende gneiss. With increasing biotite and quartz, the rock becomes finer grained and more closely foliated. Although some hornblende and plagioclase grains are commonly slightly larger than the other mineral grains, the rock loses the distinctive salt-and-pepper aspect of hornblende gneiss and acquires a more even, dark-gray color. Although closely foliated, the rock does not split evenly along a single plane; the fracture is hackly, and foliation appears to be a compromise direction between several planes of mineral orientation. As the grain size becomes smaller, the gneiss grades into dense, uniform to banded, gray rock characteristic of mylonite gneiss.

Feldspar augen and irregular quartz-feldspar stringers are abundant in muny places, particularly near hodies of quartz monzonite gneiss or pegmatite. The auartz and feldspar stringers and augen are generally parallel to the foliation, although in places they form irreryular, cloudy masses. The contacts of these masses are characteristically indistinct, and the stringers and masses apparently result from replacement or transformatio 1 rather than injection.

\section{PeTRography}

Hornblende-biotite gneisses are somewhat granulated rocks intermediate in texture between hornk lende gneiss and mylonite gneiss. Fine-grained quartz and biotite and abundant accessory minerals occur along shear zones and in recrystallized, cataclastic aggregates that surround the larger, relict grains of plagioclase and hornblende (pl. $53 \mathrm{~A}$ ); the quantity of quartz and biotite is directly related to the degree of granulation of the rock. Biotite tends to be oriented along several sets of shear planes, and the foliation is more distinct than that in typical hornblende gneiss. In plenes a single set of shear planes is dominant and in such rocks even relatively biotite-poor gneiss has good megascopic foliation. Most of the hornblende-biotite gneiss, however, shows several sets of shear planes in the diraction of megascopic foliation that intersect at low angles. Minerals are also considerably granulated between the larger crystals. In these rocks the degree of fol ation depends on the quantity of oriented biotite and on the angles of intersection of the shear planes. In some rocks cataclasis took place only between the grains; these rocks have almost no foliation. No generalization can be made concerning the relationship of degree of foliation with degree of comminution.

Hornblende and plagioclase occur as ragged relict grains set in finer, granulated rock. Broken grains of plagioclase are also abundant in the surrounding granulated rock, but fine-grained hornblende is uncommon. The grain size of the larger crystals is comparable with that in normal hornblende gneiss. Hornblende relicts generally are not as abundant as plagioclase relicts, and they are commonly altered in part to biotite. $/ / /$ here there was significant granulation, the plagioclase is distinctly more sodic than that in the associated hornblende gneiss, and generally is either sodic andesine or calcic oligoclase. Most grains are considerably sericitized and saussuritized, but relatively clear grairs also are abundant. Plagioclase generally is about as abundant in the resulting rock as it was in the original hornblende gneiss. 
Although a small quantity of biotite is commonly associated with the relict hormblende grains, most of it occurs with quartz and plagioclase in fine-grained crystalloblastic aggregates along the shear zones and between the larger plagioclase and hornblende crystals. Biotite forms irregular to well-formed platy crystals that range in size from very small grains to grains nearly as coarse as some of the hornblende crystals. Many of the biotite plates are oriented along the shear planes, but many also show random orientation in the granulated rock between the relict crystals. Depending largely on the degree of shearing, biotite ranges in abundance from a trace to about 20 percent of the rock.

Quartz forms small, about equidimensional grains associated with the recrystallized biotite and plagioclase and somewhat larger grains in elongated aggregates along shear zones. Quartz makes up as much as 30 percent of some rocks; it is generally most abundant where biotite is most abundant.

Small quantities of microcline are widespread, but it is most abundant in the vicinity of quartz monzonite gneiss and pegmatite bodies where aggregates make up the augen and granitic-appearing stringers. Microcline occurs in small wisps and irregular grains in the recrystallized cataclastic zones of the gneiss. Microcline replaces relict hornblende and plagioclase grains, as well as biotite and plagioclase in the cataclastic mortar. Several poikiloblastic microcline grains were observed that cut across granulated zones and contained biotite inclusions oriented in the direction of the shear plane; these microcline grains obviously crystallized after shearing. The transition from hornblende-biotite gneiss to the associated quartz monzonite gneiss takes place chiefly by an abrupt increase in the quantity of introduced microcline. Although microcline definitely was introduced along some granulated zones, in many places it was broken by later shearing.

Apatite, sphene, and magnetite are much more abundant in hornblende-biotite gneiss than in unsheared hornblende gneiss. They commonly make up several percent of the biotite- and quartz-rich gneiss, and in some specimens they constitute about 5 percent of the rock.

Irregular grains of epidote are scattered through most of the rock. They are erratically distributed, generally in minor amounts, although in places epidote forms as much as 15 percent of the gneiss.

\section{ORIGIN}

The transition from hornblende gneiss through intermediate hornblende-biotite gneiss and schist to mylonite gneiss is marked by progressively more intense shearing and granulation. In all these rocks, only hornblende and plagioclase occur in the relatively large relict crystals; the groundmass consists essentially of a fine aggregate of crystalloblastic biotite, quartz, and feldspar. The transformation involved granulation of the original hornblende gneiss by penetrative movement and shearing. Plagioclase was broken and altered to a somewhat more sodic feldspar, but the quantity of plagioclase in the rock did not change appreciably. Hornblende, on the other hand, was broken down and the constituent materials recrystallized as $\Sigma$ mixture of biotite, quartz, and the lime-bearing accessory minerals apatite, sphene, and epidote. These new minerals did not form pseudomorphs after hornblende but occur scattered through the granulated part of the rock.

As indicated by the relations of microcline along granulated zones in the rock, the shearing was accompanied by local feldspathization. The cataclasis, therefore, appears to have taken place during the same general period of time in which regional metasomatism produced the quartz monzonite gneiss and pegmatite elsewhere in the district.

Some of the potash required by biotite could have been derived from external sources, and perhaps some quartz also may have been introduced, but the increase in abundance of biotite and quartz with increase in degree of granulation and decrease in al undance of hornblende makes a local source more probable. However, most biotite in the granulated zones shows no relation to broken hornblende remnants and quartz is unevenly distributed so the recrystallization of materials derived from sheared hornblende inrolved some movement in solution. Possibly this accounts for the variable quartz-biotite ratio and the erratic distribution of the lime-bearing accessory minerals.

\section{MYLONITE GNEISS}

GENERAI FGATURES AND DISTRHBU'TON

The mylonite gneiss is made up of very fine grained crystalloblastic rocks that originated through intense shearing and granulation, followed by moderate recrystallization, of the different rocks in the gneiss complex. These rocks vary widely in mineral composition, depending on the composition of the original gneiss, on the intensity of shearing, and on the degree of recrystallization. Many of the rocks are streaked with discontinuous layers of contrasting color and composition, and rounded to lozenge-shaped augen are common. Following the nomenclature compiled by Waters and Campbell (1935, p. 478, 481), these rocks are called mylonite gneiss; locally, rocks have been so intensely sheared that all original textures were destroyed and these are classed as ultramylonites.

Mylonite gneiss is most abundant along the walls of Kings and Pinkham Creek Canyons; smaller areas of 
this rock are exposed in the core of Sentinal Mountain and along the front of the Medicine Bow Mountains northeast of Sentinal Mountain (pl. 48). Mylonite gneiss is most abundant where the original rock was dominantly hornblende gneiss; it dies out to the east and south in large masses of quartz monzonite gneiss. The margins of some large quartz monzonite gneiss bodies were reduced to mylonite; but short distances in from the contacts only a minor amount of intergranular cataclasis took place.

\section{LTTHOLOGY}

Most mylonite gneiss derived from hornblende gneiss is a very fine grained medium- to dark-gray micaceous rock that is closely foliated and in part streaked. The streaks are due to alternating biotiterich and feldspar-rich layers that are commonly folded and crenulated on a small scale. Hornblende crystals occur in bands along the folia of some of these rocks. The foliation is uneven, and fractures commonly sparkle with reflections from abundant fine biotite. Rounded feldspar augen are relatively common, and in places they are strung out along layers like series of beads.

A dense, white to greenish-gray, slightly greasyappearing rock that may have been either a limesilicate rock or a normal hornblende gneiss occurs along the walls of Pinkham Creek Canyon. This rock is made up of a very fine aggregate of epidote and clinozoisite and minor amounts of quartz. Much of it is megascopically structureless, but quartz-rich varieties show faint streaks parallel to the foliation of the adjacent gneiss.

Quartz monzonite gneiss was more resistant to shearing than hornblende gneiss, hence only the marginal parts of larger bodies even in the zones of greatest movement were reduced to mylonite. Many of the smaller bodies, however, were ground up to a very fine-grained pinkish-gray rock with a distinct quartzitic appearance. These siliceous-appearing rocks commonly show color banding parallel to the foliation of adjacent rocks. Where granulation was not so complete, remnants of abundant rounded to ovoid pink feldspar grains are set in a thin-layered, vitreousappearing groundmass. The crinkled layers bend around the augen much as flow bands in lava bend around phenocrysts. Moderately sheared quartz monzonite gneiss is distinctly finer grained and better foliated than normal quartz monzonite gneiss, but the cataclastic texture is not generally obvious.

Most mylonite gneiss derived from pegmatite has a distinctive appearance. Abundant rounded to lozengeshaped augen of pink feldspar as much as several inches in diameter are surrounded by a fine groundmass with a streaked, pseudofluidal texture. The contrasting colors of the pink to gray "flow bands" that branch and bend around the pegmatite relicts and augen are due largely to the tendency of quartz and feldspar to segregate into separate layers. Minor amounts of biotite and muscovite occur along some of the folia and accentuate the banding. Where the original rock was completely ground it is difficult to determine if the light-gray to pink ultramylonite was derived from quartz monzonite gneiss or from pegmatite.

\section{PETROGRAPHY}

The common dark-gray mylonite gneiss derived from hornblende gneiss shows an excellent recrystallized cataclastic texture under the microscope. Rounded and broken plagioclase augen, generally calcic oligoclase, are set in a fine, crystalloblastic groundmass of feldspar, quartz, and biotite (pl. $53 B$ ). Horr blende crystals are few or absent in most specimers, but locally they are abundant and are concentrated along relatively hornblende-rich layers. Some horrblende occurs in recrystallized, poikiloblastic grains (pl. $53 \mathrm{C}$ ). Curving streaks, or "flow bands" marked by abundant biotite flakes, branch and bend around the rounded feldspar augen. Those rocks that were reduced to a fine-grained cataclastic aggregate with very few larger grains, later recrystallized to fairly even textured, dense rocks composed of biotite, feldspar, and quartz grains that are generally 0.2 millimeter or less in diameter. The megascopic banding is commonly indistinct under the microscope. Much quartz occurs in the recrystallized cataclastic rock, but some aggregates and microscopic veinlets string out along the curving bands. Epidote, apatite, and sphene are common accessory minerals. This rock is the end member of the transitional series called hornblende-biotite gneiss that grades from slightly sheared hornblende gneiss to mylonite gneiss.

The fine-grained, white to greenish-gray rock of uncertain origin that occurs along Pinkham Creek Canyon is composed largely of clinozoisite and epidote with lesser quantities of quartz. Some epidote and clinozoisite crystals are 1 millimeter long; most grains are less than 0.5 millimeter in diameter. Quartz makes up only 10 to 20 percent of most of the rock, but locally it is much more abundant and tends to occur in bands or streaks. Sphene is a common minor accessory mineral.

All gradations exist between slightly sheared quartz monzonite gneiss and ultramylonite. Some rocls that appear in hand specimen to be relatively fine grained quartz monzonite gneiss show marked intergranular cataclastic texture in thin section. Where sl aaring was not intense, granulation was confined to relatively thin zones along grain margins. With an incriase in 
degree of shearing, the zones of intergranular brecciation became wider, and integrated shear zones cut through the rock (pl. $53 \mathrm{D}$ ). These shear zones generally intersect at relatively low angles in the direction of megascopic foliation. Where the ultramylonite stage was reached, most of the original grains are milled out to a fine cataclastic aggregate, and one of the several intersecting shear planes generally is dominant. The relict feldspar augen that survived are rounded and fractured, in places giving the appearance of having been rolled. Some of the larger grains show the external form of augen, but under crossed nicols they appear almost as thoroughly brecciated as the groundmass (pl. $53 E, F$ ). With extreme granulation almost all the original grains were pulverized, and shearing separated the different minerals in the groundmass into quartz-rich and feldspar-rich bands that bend around the ovoid feldspar augen. Most of the recrystallized grains in these rocks are less than 0.3 millimeter in diameter.

The composition of plagioclase apparently was not greatly altered during the granulation of quartz monzonite gneiss. Although plagioclase in the groundmass is too fine grained to determine its composition accurately, it appears to have about the same index of refraction as the associated augen, which are either calcic albite or sodic oligoclase. Biotite was broken down into chlorite and sericite, which occur as scattered wisps and shreds through the rock. Although the cataclastic origin of the rocks is obvious, the present texture is crystalloblastic. Quartz apparently recrystallized most easily and is distinctly coarser than the feldspar. All grains have irregular, interlocking contacts.

Pegmatite underwent the same general changes as quartz monzonite gneiss. The augen tend to be much larger than those in comparably sheared quartz monzonite gneiss, but the streaked groundmass in both rocks has the same aspect.

\section{STRUCTURE}

Foliation in hornblende-biotite gneiss and mylonite gneiss is parallel to that in the associated unsheared rocks, and lineation shown by minor fold axes and mineral elongation conforms closely to that in hornblende gneiss (fig. 69). Apparently the same general stress field persisted through regional metamorphism and dynamic metamorphism, but the type of deformation changed from isoclinal folding to more localized shearing and granulation.

Only the northern margin of the belt of sheared rocks is well exposed in the Northgate district; the rest of the belt is overlain by younger sedimentary rocks, and Laramide reverse faults make the relationship more

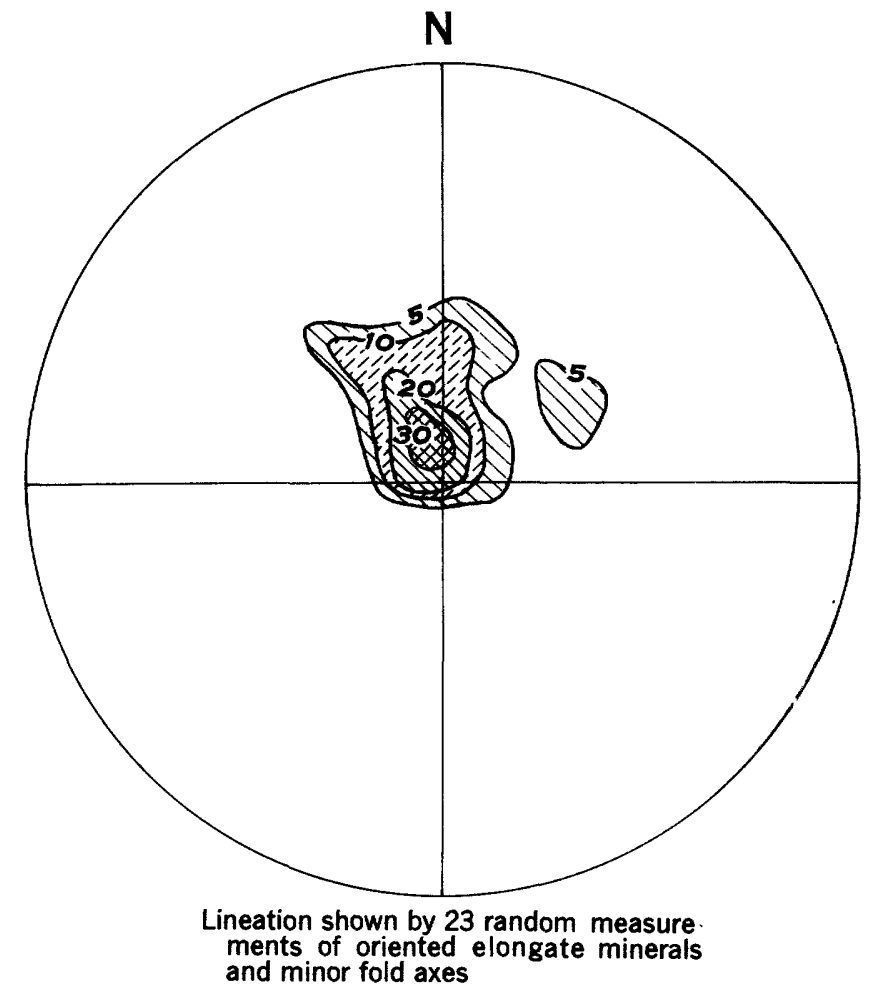

Figure 69.-Lineation in hornblende-biotite gneiss and mylonite gneiss. Contours on $5,10,20$, and 30 percent concentrations per 1 percent of the area. Plotted on the lower hemisphere of a Schmidt equiarea net.

confusing. The northern margin of myln ite gneiss is irregular but fairly sharp, and generally is about parallel to the regional trend of foliaticn. A small copper prospect adit along Pinkham Cree ${ }^{l_{r}}$ near the eastern edge of the district crosses part of the zone of mylonite gneiss in a mass of relatively unsteared rock. Surface exposures indicate that the rock is unaltered, but careful inspection of the walls of the acit disclosed that many narrow bands of granulated rock cut the otherwise unsheared hornblende gneiss. Presumably the irregularities on the northern margin of the mylonite gneiss were due to local concentration of the movement into narrow zones. The hornblende-biotite gneiss to the north of the zone of most intense shearing resulted from relatively minor, irregularly distributed movement.

Mylonite gneiss merges to the east into large masses of quartz monzonite gneiss. The margins of these large bodies generally show intense granulation, but this feature is lost a short distance from the edge of the bodies where the rocks appear similar to the quartz monzonite gneiss in the rest of the district. Evidently the large bodies of quartz monzonite gneiss were massive enough to resist penetrative shearing that reduced the smaller bodies and weaker rocks to mylonite.

The apparent offset of the northern margin of the belt of mylonite gneiss across the Independence 
Mountain fault zone near Kings Canyon (pl. 48) probably is misleading, as this offset is the reverse of that to be expected along a northward-dipping reverse fault. More probably the broad zone of mylonite gneiss contains relatively large masses of ungranulated rock, or is made up of several distinct bands of mylonites, and the actual northern margin may not be exposed south of the Independence Mountain fault.

\section{ORIGIN}

Mylonite gneiss resulted from the intense granulation of all rocks in the gneiss complex during the same period of shearing that produced hornblende-biotite gneiss. As pegmatite and quartz monzonite gneiss bodies (formed at an earlier stage in the shearing) were reduced to mylonite, the belts of intense granulation apparently formed late in the period of shearing. The relative movement between the rocks in the northern and southern parts of the district apparently has become more and more localized along certain zones as the shearing progressed.

\section{RHEOMORPHIC QUARTZ MONZONITE GNEISS}

GENERAL FEATURES AND DISTRIBUTION

Some quartz monzonite gneiss in the northwestern and southeastern parts of the Northgate district shows evidence that it became mobile, or rheomorphic, after it was transformed, and intruded the surrounding rocks as diapirlike injections. The banded structure of normal quartz monzonite gneiss was largely destroyed, and a more uniform, aplitic texture was formed. Where movement was not great, highly contorted original banding still can be recognized, and this banding is commonly cut by a new, less distinct foliation. The foliation of unreplaced hornblende gneiss inclusions shows great departures from the regional east and northeast trend of foliation and layering, and reflects major features of deformation resulting from movement of mobile quartz monzonite gneiss.

The name quartz monzonite gneiss as applied to the rheomorphic rock in the Northgate district is not strictly accurate in all places. Much of the rock is alaskitic in composition and has an aplitic rather than gneissic texture. Microcline is commonly more abundant than plagioclase, and many rocks are granitic rather than quartz monzonitic in composition. Foliated and quartz monzonitic rocks are relatively common, however, and the different compositional and textural types are complexly intermixed throughout the areas of rheomorphism. As these variations were not mapped separately during field work (pl. 48), the unsatisfactory genetic name rheomorphic quartz monzonite gneiss has been used for convenience and to avoid confusion with a younger quartz monzonite believed to be of intrusive origin (see "Intrusive quartz monzonite").

Evidence for rheomorphism is clearest in the northwest corner of the district, where a funnel-shape 1 mass of quartz monzonite gneiss about $1 \frac{1}{2}$ miles long by $3 / 4$ mile wide intruded and deformed the rocks in the adjacent gneiss complex (pl. 49). Relict features and the unhomogeneous character of adjacent larers of rheomorphic quartz monzonite gneiss indicate that the movement was not as a true melt. Similarly deformed quartz monzonite gneiss occurs along the sortheast edge of the mapped area and may be marginal to a larger mass of formerly mobile rocks. Relationships in that area are so poorly understood that the following discussion will deal largely with the area in the northwest part of the district.

\section{STRUCTURAL SETTING}

The funnel-shaped mass of once mobile quartz monzonite gneiss near the northwest corner of the district consists of discontinuous layers of quartr monzonite gneiss and minor amounts of hornblende gneiss which close completely around it and give it a distinct annular appearance. Layers dip $60^{\circ}$ to $70^{\circ} \mathrm{N}$. on the south flank, $80^{\circ}$ to $85^{\circ} \mathrm{W}$. on the east nose, $80^{\circ} \mathrm{N}$. through vertical to $85^{\circ} \mathrm{S}$. on the north flank, and the northwest nose plunges $50^{\circ}$ to $60^{\circ} \mathrm{SE}$. (pl. 49). Where annular layers are parallel or nearly parallel to the foliation or banding in the surrounding gneiss complex; margins of the funnel-shaped mass are completely gradational. They grade into normal rocks of the gneiss complex to the south and into highly deformed rocks to the west and southwest; the northern margin is outside the area mapped and was not ob erved. The highly deformed layering in the rocks to tha west and southwest splits and bends around the northwestern nose of the "funnel," and rocks in the ricinity of the nose are massive, nearly structureless quartz monzonite. The eastern nose of the funnel-shaped structure is sharply transgressive against adjacent hornblende gneiss and pegmatite, and the c.nnular layers cut almost at right angles across the more normal trend of the country rocks. Massive rock marks the transition between the funnel-shaped mass of quartz monzonite gneiss and the surrounding rocks in the areas where the annular layers swing from nearly normal to parallel to the adjacent banding and foliation. New structures are most prominent along the flanks of the funnel-shaped mass where most movement app qrently was concentrated; some relict structures can be recognized in the core and toward the outside edges of the "funnel."

The area of highly deformed rocks to the west and southwest of the funnel-shaped mass contains horn- 
blende gneiss and quartz monzonite gneiss that range from nearly normal rocks of the gneiss complex to massive, recrystallized rocks having no relict textures. In the absence of distinctive horizon markers, it is difficult to determine the details of structure in this area, but the relationship of the deformed hornblende gneiss inclusions indicates the general course of deformation. The axial plane of a northward-plunging fold adjacent to the funnel-shaped mass trends almost at right angles to the axial planes of folds in regionally metamorphosed rocks away from the area of rheomorphism. Original small-scale layering in the quartz monzonite gneiss was highly crumpled during this

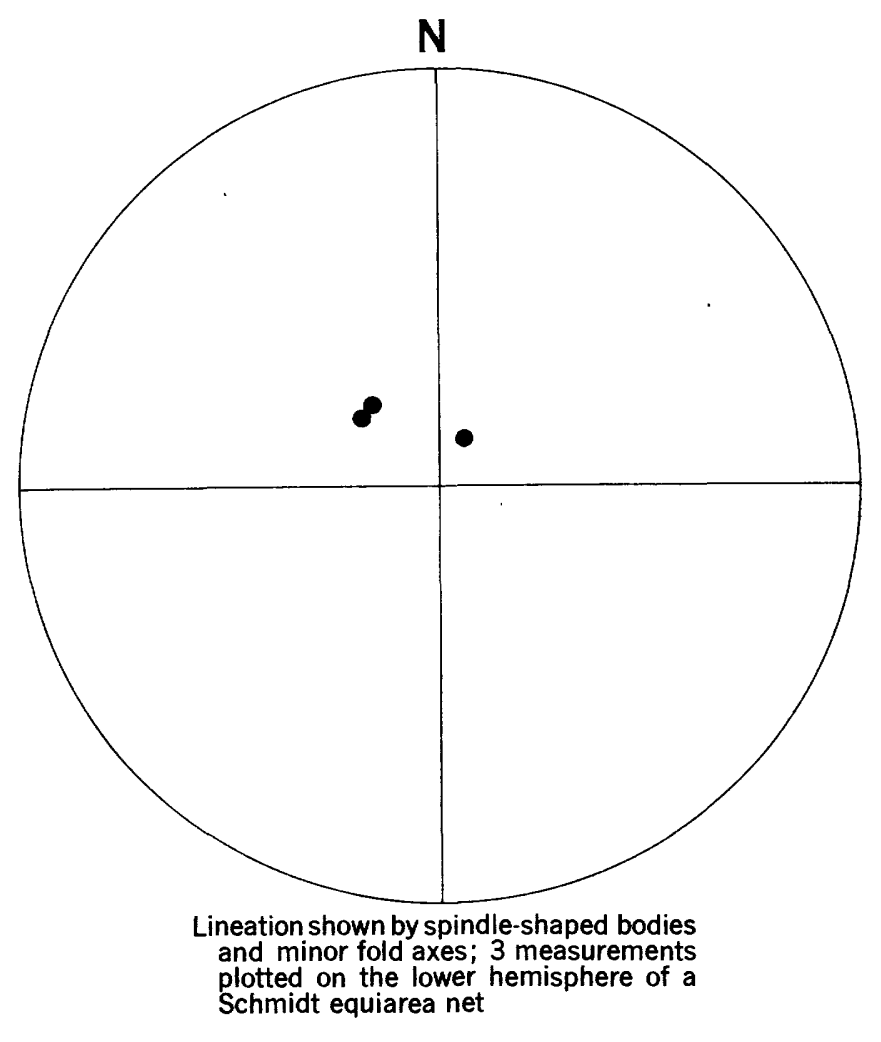

Ficure 70.-Lineation in rheomorphic quartz monzonite gneiss.

deformation, indicating that rheomorphic deformation followed metasomatic transformation. Some thin layers in the original quartz monzonite gneiss were milled out into spindle-shaped masses 1-2 inches in diameter and 1-2 feet long. Lineation shown by these spindles and by the contorted layers conforms to the same pattern of lineation in regionally metamorphosed hornblende gneiss and in the later, dynamically metamorphosed mylonite gneiss (see fig. 70). Apparently the same stress field persisted through regional metamorphism, metasomatic and dynamic metamorphism, and mobilization.

Deformation of the rock west of the funnel-shaped structure apparently was accompanied by rock flowage, particularly of the quartz monzonite gneiss. The larger folds show thickening on limbs and crests, and new structures are best displayed in areas of greatest apparent thickening. 'The southern margin of the large mass of quartz monzonite gneiss that encloses the rock believed to have been mobile follows the normal regional trend of the gneiss complex. Noting the part of the large, northward-trending cross fold within the outermost discontinuous arc of hornblende gneiss inclusions (pl. 49), it can be seen that the fold starts on the west from an interlayered series of quartz monzonite gneiss and hornblende gneiss about 1,500 feet thick. The hornblende gneiss inclusions in the fold show a progressively wider spacing outward from tha core, and the interlayered series of rocks where the fold loses its identity to the east is nearly twice as thick as at the western end. Much of the apparently thickened quartz monzonite gneiss in the core and eastern limb of the fold is massive, and only minor relict texture survived deformation. If the outer, discontinuous ba nd of hornblende gneiss inclusions were straightened ont, it would extend nearly to the east end of the mass showing annular flow structure. Thus the intrusion of the funnel-shaped diapir of mobile quartz monzonite gneiss apparently forced the displaced rocks to flow relatively westward, and the movement is recorded by the folding. Quartz monzonite gneiss shows the greatest thickening, but local bulging of hornblende gneiss inclusions indicates that this rock also underwent flowagis. No surfaces of discontinuity other than the layerir 3 were discovered in this area, and apparently the deformation was wholly by flow and without faulting.

The area between the northward-trending fold and the North Platte River underwent deformation as intense as that in the area to the east. The hornblende gneiss inclusions are highly contorted and irregular, and the larger bodies of quartz monzonite gneiss are massive, as though they too were thickened. The relationship is believed to record the movement of relatively mobile quartz monzonite gneiss, but geologic data on adjacent areas are insufficient to permit an evaluation of the structures.

The markedly different behavior of the rocks east and west of the funnel-shaped mass is probably due to differences in the mobility of the surroun ling rocks. The large mass of quartz monzonite gneiss feathers out into hornblende gneiss a short distance east of the "funnel"; the rocks here probably were somewhat cooler and more brittle, and the flow stricture cuts sharply across them. Quartz monzonite gneiss is abundant west of the funnel-shaped mass, and reconnaisance west of the North Platte River disclosed that it is the dominant rock there also. Apparently toward the interior of this large mass of quartz monzonite 
gneiss the rock was so soft that it deformed readily during local movement of more mobile rock.

The crumpling, steeply inclined fold axes, and evidence for lateral displacement within rocks to the west and southwest of the funnel-shaped intrusion closely correspond to the general description given by Wegmann $(1930$, p. 70$)$ for examples of diapir injection in southern Finland.

\section{LITHOLOGY}

Rocks in the area where the quartz monzonite gneiss is believed to have been widely mobilized show all gradations in the destruction of the preexisting layered structure of quartz monzonite gneiss and the formation of a variable, but generally aplitic texture. Although still medium grained, most of the rocks are somewhat coarser than the nonrheomorphic quartz monzonite gneiss and many of the grains are 3 millimeters or more in diameter. Typically, the rock consists of quartz and feldspar and a little biotite which form an even-grained pink aggregate. The biotite is oriented nearly parallel to the larger scale layering, but in most rocks it is sparse and widely scattered and the foliation is weak. Locally biotite is more abundant and forms thin, discontinuous bands, rendering the rock distinctly gneissose.

Although most rocks show little banding or foliation in a hand specimen, they are distinctly layered on a larger scale. The layers recognized in outcrops range from a few feet to a few tens of feet in thickness. Many adjacent layers differ only slightly or not at all in texture and composition; elsewhere the rocks of the several layers differ markedly. Hornblende gneiss is abundant in the area of deformed rocks west and southwest of the funnel-shaped mass and, although subordinate, is widespread within the funnel-shaped mass showing annular layers. Inclusions of hornblende gneiss are oriented parallel to the layering in rheomorphic quartz monzonite gneiss, and the contacts of the inclusions are sharp.

Quartz monzonite gneiss with highly contorted but still recognizable original layering is the most abundant country rock throughout the area of apparently folded rocks west and southwest of the funnel-shaped mass. In most places a new foliation cuts the deformed layers, and all stages in the disruption of the original texture can be seen. The original layering is still readily recognizable where it is parallel to the new foliation, but it is hazy and indistinct where it is cut by the new foliation. Relict textures are best displayed in the smaller bodies or near the margins of the larger masses of quartz monzonite gneiss; they were largely destroyed in areas where significant thickening took place.

Irregular pegmatitic masses occur throughout the rheomorphic quartz monzonite gneiss. These masses have gradational margins and apparently formed by local recrystallization that obliterated all previous structures, including the crumpled original layer: ng and the later, indistinct foliation and layering related to rheomorphic movements.

Though generally sparse, biotite is the most common ferromagnesian mineral in the rheomorphic quartz monzonite gneiss. Hornblende, or hornblende and biotite, occurs in some layers, and the rock, although still leucocratic, commonly has a slightly different aspect than biotite-bearing quartz monzonite gneiss. In outcrop, hornblende-bearing rocks appear somewhat more closely knit and blocky, the color generally is lighter, and where hornblende makes up more than a few percent of the rock it gives the rock a distinctive foliation. 1 10st of these differences are so minor that they are diff rult to describe, but the rocks can be recognized readily in the field.

Hornblende gneiss inclusions appear much th 9 same as normal hornblende gneiss in the rest of the gneiss complex, although locally the plagioclase and hornblende occur in light- and dark-colored clusters.

\section{PETROGRAPHY}

The rheomorphic quartz monzonite gneiss commonly is an aggregate of plagioclase, microcline, and quartz ranging in texture from typically crystalloblastic with mutually interfering grain boundaries to mixtures of crystalloblastic and replacement textures. Accessory minerals are biotite, hornblende, magnetite, and garnet. Except for the minor biotite, minerals in thes? rocks show little or no dimensional orientation but occur in aggregates of equidimensional, xenoblastic grains. Although most rocks appear equigranular in hand specimen, they show a wide range of grain size in thin section.

Plagioclase in the rheomorphic quartz monzonite gneiss for the most part is clear or only slight] ${ }^{r}$ saussuritized. In the more common, biotite-bearing and alaskitic facies, most plagioclase is between $A n_{5}$ and $\mathrm{An}_{15}$ in composition; in hornblende-bearing quartz monzonite gneiss, most of it is somewhat more calcic. Plagioclase forms nearly equidimensional grains as much as 2.5 millimeters in diameter in rocks with distinct crystalloblastic texture, but most of it is corroded by microcline and quartz and shows all stages of replacement. Many plagioclase grains show the effects of minor deformation that was not shared by the adjacent microcline and quartz (pl. $54 A, B$ ). Twin lamellae are distorted, grains show wavy ext:nction, and some crystals were broken into mosaics of smaller grains with slightly differing orientations. Only a small percentage of the plagioclase grains are distorted or broken, but the minor cataclasis took place thrc ighout 
the area where rocks were mobile. The grains evidently were bent and broken while the rocks were being deformed, and these plagioclase grains, evidently, survived movement without significant recrystallization.

Myrmekite is widespread in the rheomorphic quartz monzonite gneiss and occurs most commonly along the margins of plagioclase adjacent to microcline (pl. $54 C$ ). The myrmekite formed subsequent to the brecciation and deformation shown by some of the plagioclase grains.

Microcline crystals range from mere intergranular wisps to relatively large, poikiloblastic grains 3 millimeters or more in diameter that enclose relict inclusions of plagioclase. Locally some grains have mutually interfering, crystalloblastic relationships with the adjacent minerals, but in many places, microcline is interstitial to plagioclase and tongues project into broken plagioclase grains along fractures or strained zones clearly showing replacement relations toward plagioclase (pl. $54 A-C$ ). Twinning is slightly distorted in a few grains of microcline, but adjacent grains show no related cataclastic texture. Although microcline varies greatly in grain size, most crystals are medium grained and are either of about the same size as the associated plagioclase crystals or a little coarser.

Quartz evidently recrystallized during a relatively long period. It occurs with plagioclase and microcline in the crystalloblastic aggregates, and as lobate to irregular grains that cut microcline as well as plagioclase and biotite. When observed under low magnification and with crossed nicols, quartz in many rocks appears as an overprint of lobate to irregular grains impressed on the microcline and plagioclase aggregate. Grain size of the quartz is highly uneven; the grains in the crystalloblastic aggregates are nearly as large as the associated feldspar grains and are coarser and more irregular than the lobate to rounded grains that cut microcline. Quartz also did not share the deformation shown by some plagioclase and in many places preferentially replaced the strained parts of plagioclase crystals (pl. $54 \mathrm{~B}$ ).

The irregular masses of pegmatitic rock that cut the crumpled layers of rheomorphic quartz monzonite gneiss formed through the more complete recrystallization of microcline and quartz following rheomorphic deformation. The relationship is somewhat similar to those observed in most thin sections where microcline and quartz are corrosive toward plagioclase and biotite.

Biotite rarely makes up more than a few percent of the rheomorphic quartz monzonite gneiss, and much of the rock carries only a trace as small, corroded shreds and grains with abundant associated magnetite. Magnetite is generally most abundant where biotite is most highly corroded. A few layers of the rock, however, contain as much as 10 percent of biotite, and it either forms a crystalloblastic aggregate with plagioclase, microcline, and quartz or has mutually interfering contacts with plagioclase and is embayed irregularly by microcline and quartz. Where biotite is most abundant, the flakes are as much as $1 \frac{11}{2}$ millimeters long, but most of the corroded shreds are less than 1 .

Magnetite is more abundant in rheomornhic quartz monzonite gyeiss than in - normal quartz monzonite gneiss, and in places constitutes as much a 2 percent of the rock. It occurs as small, equant crystals 1 millimeter or more in diameter scattered through the rock and as dusty grains associated with the-resorbed biotite. Many of the larger grains tend to be idiomorphic. The relative increase in magnetite and a decrease in biotite content and the close association of magnetite with corroded biotite crystals indicate that much of the disseminated magnetite was produced by recrystallization of material left from the destruction of biotite.

Small, rounded to idiomorphic, red garnet crystals as much as 2 millimeters in diameter occur through the rheomorphic quartz monzonite gneiss. They show no evidence of their origin, but it is likely that they are recrystallized relicts that survived mobilization and deformation.

Hornblende occurs in some of the discontir uous layers of quartz monzonite gneiss in the funnel-sl aped mass and in the deformed rocks to the west and southwest. It ranges from mere traces to 10 percent of some rocks and generally is most abundant where micro line makes up 25 percent or less of the rock. Irregular grains of hornblende generally have mutually interfering contacts with plagioclase grains, and, in those rocks that have minor replacement relationships, with microcline and quartz grains as well. Where microcline is abundant, the hornblende occurs in small ragged grains irregularly embayed by microcline.

Sillimanite, and associated muscovite, was found in two specimens from the rheomorphic quartz monzonite gneiss; it makes up nearly 15 percent of a resistant, spindle-shaped body about 2 irches thick and $1 \frac{11}{2}$ feet long from the area of deformed rocks, and a little was seen in a specimen from the north flank of the funnel-shaped mass. In this specimen, the sillimanite and muscovite occur alcng several closelv spaced fractures that cut the crystalloblastic texture of the rheomorphic rock. The minor shear zones were largely healed by later recrystallization, and the muscovite and sillimanite are both younger than the shearing. Sillimanite forms single needles and sheaves, and also bundles enclosed in muscovite, microcline, or quartz. Much of the muscovite has a peculiar, myrmekitic texture with irregular, wormy 
quartz inclusions, and in part is closely associated with biotite and apparently formed from it. Petrographic relationship suggests that biotite along the shear zone altered to muscovite and minor magnetite, and that muscovite in turn altered into sillimanite and perhaps microcline. The materials migrated considerably during recrystallization, and details of the alteration are obscure. Sillimanite and muscovite, however, are confined to the shear zones; muscovite is associated with either biotite or sillimanite. This distribution indicates a progressive alteration. A similar sequence is indicated by relationships to the spindle-shaped body, but greater migration of recrystallizing materials makes interpretation difficult.

The biotite-bearing and alaskitic varieties of rheomorphic quartz monzonite gneiss carry significantly more microcline than the average quartz monzonite gneiss elsewhere in the district. Seventeen specimens from the funnel-shaped mass and the deformed rocks to the west ranged from 30 to 50 percent, and averaged 41 percent microcline. The average microcline content of 22 specimens of typical quartz monzonite gneiss from all parts of the district was only 32 percent, ranging from 10 to 50 percent and with the great majority between 20 to 40 percent. The plagioclase content $\left(\mathrm{An}_{5-15}\right)$ averages only 25 percent in the 17 specimens of rheomorphic gneiss; of these only 7 can be classed as quartz monzonitic or granodioritic, whereas the remaining 10 are truly granitic in composition.

Only traces of biotite are present in 9 of the 17 specimens of rheomorphic rock; 5 specimens have 1 to 5 percent, and 3 have 5 to 10 percent biotite. Magnetite is an abundant accessory mineral in all the specimens and makes up 1 to 2 percent of 10 or more of them. The quartz content ranges from 25 to 50 percent and averages 35 percent in the 17 specimens.

Hornblende-bearing rheomorphic quartz monzonite gneiss varies much more in composition than the more common varieties of rheomorphic quartz monzonite gneiss. The quartz content is uniform and ranges from 30 to 35 percent in all specimens studied. Microcline ranges from mere traces to 50 percent of the rock and generally is irregularly distributed. Of eight specimens studied it averages almost 30 percent. Mutual crystalloblastic relationship is more common in these rocks than in the biotite-bearing rocks, but even here most microcline tends to embay the plagioclase and hornblende (pl. $54 D$ ). Plagioclase ranges from 20 to 60 percent of the eight specimens studied and averages about 35 percent. The composition. ranges from $A n_{10}$ to $A n_{26}$ and averages $A n_{20}$. Plagiocase is generally most calcic where it is most abundant, but in one specimen with only traces of microcline, sodic oligoclase $\left(\mathrm{An}_{12}\right)$ makes up nearly 60 percent of the rock, while in another, calcic oligoclase $\left(\mathrm{An}_{26}\right)$ makes up only 20 percent and is subordinate to microcline. Deformed plagioclase grains occur in four of the eight specimens studied. The hornblende content also varies greatly; two of the eight specimens studied contain only traces, four contain 1 to 5 percent, and the other two 5 to 10 percent. Where it is most abundant the hornblende occurs in a crystalloblastic aggegate with plagioclase, and locally with microcline and quartz. Generally it is somewhat corroded, and where it is only a minor constituent, it forms small ragged wisps and grains. Magnetite constitutes as much as 2 percent of these rocks and is even more abundart here than in the biotite-bearing varieties. Traces of biotite occur in all these rocks.

The inclusions of hornblende gneiss in rheomorphic quartz monzonite gneiss resemble normal hornblende gneiss in hand specimen, but in thin section they display a completely recrystallized texture (pl. : $4 E$ ). The hornblende and plagioclase grains are more equant and much less irregular than in regionally metamorphosed hornblende gneiss. In all specimens studied the plagioclase is highly saussuritized and sericitized and ranges in composition from $\mathrm{An}_{30}$ to $\mathrm{An}_{35}$. \& little quartz is widespread, generally in small, rounded blebs. Some specimens show a tendency toward mineral segregation and have irregular clusters of somewhat coarser hornblende and plagioclase set in the more typical hornblende-plagioclase aggregate.

\section{ORIGIN}

The quartz monzonite gneiss in the larger bodies near the northwest and southeast corners of the $I^{\top}$ orthgate district show many features that seem best explained by local mobilization of the gneiss following metasomatic transformation. The foliation and layering characteristic of the quartz monzonite gneis elsewhere in the district are highly deformed, and are progressively destroyed with an increase in the degree of deformation. Near the northwest corner of the district, a funnel-shaped mass consisting largoly of concentric layers of quartz monzonite gneiss appears to have intruded the adjacent rocks. The mass is sharply transgressive at its east end, and grades into highly deformed rocks along its western and southwestern margins. The contorted structures in the marginal rocks are most easily explained by plastic deformation of relatively mobile rocks shouldered aside by the invading funnel-shaped mass.

The widespread occurrence of relict textures and structures throughout the area of rheomorphisn, the marked contrast in composition between many adjacent layers, and the petrographic evidence for intergranular 
shear suggest plastic rather than fluid movements. The rheomorphic intrusion and deformation apparently resulted from penetrative intergranular movements combined with shear between layers.

Crumpled layering and the gradual destruction of normal quartz monzonite gneiss textures and the formation of new textures with an increase in degree of deformation indicate that the mobilization followed the metasomatic transformation. As the lineation shown by spindle-shaped bodies and axes of small crenulations in contorted gneiss is parallel to that in the regionally and dynamically metamorphosed rocks, the mobilization presumably took place under the same stress field. Corrosive relationship of microcline and quartz grains and the irregular pegmatitic masses that obliterate earlier structures indicates that silica- and alkali-bearing solutions similar to those active in metasomatic transformation persisted through rheomorphism. Thus it seems probable that the change from regional metamorphism to dynamic and metasomatic metamorphism and to rheomorphism reflected a progressive change in conditions during a single orogenic episode.

\section{CONDITION OF ROCKS}

The funnel-shaped mass of quartz monzonite gneiss is the only structure within the area of rheomorphic rocks near the northwest corner of the district that cannot be explained by plastic deformation of rocks that previously occupied nearly the same position they now fill. Although from geometric considerations alone the funnel-shaped structure conceivably could have resulted from rotation of a relatively resistant mass of rocks, several lines of evidence indicate that the "funnel" originated through plastic intrusion of a relatively soft mass of rocks.

If the deformed rocks west and southwest of the funnel-shaped mass were straightened out and corrected for thickening, they would occupy much of the area now filled by the rocks in the funnel-shaped mass. Thus the funnel-shaped mass appears to be a foreign body that intruded the surrounding rocks, deforming and displacing them relatively westward.

The rocks in the funnel-shaped mass are indistinguishable from many of the more deformed and thickened rocks in the adjacent areas. These grade into normal rocks of the gneiss complex with a decrease in the intensity of deformation and recrystallization. The destruction of old textures and formation of new thus provides a crude measure of the extent of deformation. As relict textures are almost completely absent on the flanks of the "funnel," it appears that the rocks here were more mobile than the most plastic rocks in the adjacent, highly deformed masses where relict textures are still widespread.
Had the funnel-shaped structure orininated by rotation of a relatively resistant mass of rocks, the annular layers would have originated through differential rotation of the different layers. It is significant that these layers are neither most prominent nor most closely spaced near the periphery, as might be expected if the rocks composing the "funnel" were resistant; instead the layers, though well formed throughout the structure, are somewhat more prominent near the middle of the limbs, indicating that the differential movement was evenly distributed. The amount of differential movement between the layers appears to have been great. For example, inclusions of hornblende gneiss near the northwest and southeast ends of the mass were so dragged that their foliation strikes at right angles to the regional trend. The amount of rotation indicated by the map pattern, however, is so small that the distributive movement kgtween any two layers would be almost unmeasurable and certainly inadequate to account for so great a drag.

\section{METHOD OF MOVEMENT}

The method by which the rheomorphic rock moved was such as to yield relatively homogeneous layers with similar or contrasting composition, separated by sharp discontinuities. The hornblende gneiss inclusions and the quartz monzonite gneiss that still shows such relict features as crumpled original layering, apparently retained structural continuity during deformation and acted as plastic solids. To what extent the rocks with entirely new textures behaved as plastic solids and to what extent as viscous fluids are questions considerably more difficult to answer. Many of the alsskitic rocks are structureless or only slightly gneisso $\wedge$ in hand specimen, but they occur in discontinuous layers that close around the funnel-shaped mass. "Nithin each layer the rocks are relatively uniform and may be either very similar to or markedly different from rocks in adjacent layers. Layering is fully as distinct where rocks in adjacent layers are almost indistinguishable from each other as where they contrast sharply; evidently the layering is an essential strueture of the rocks.

Leucocratic hornblende-bearing quartz monzonite gneiss is a minor but widespread rock in the funnelshaped mass and in the more deformed parts of the adjacent rocks. This rock shows the r?crystallized texture of rheomorphic rocks, but is extremely variable in composition. The plagioclase is genorally more calcic, and the microcline is less abundart and more irregularly distributed than in the more common varieties of rheomorphic quartz monzonite gneiss. Hence the hornblende-bearing rheomorphic rock is more closely related mineralogically to hornblende 
gneiss than to quartz monzonite gneiss and probably originated from hornblende gneiss by penetrative shearing while the rocks were mobile.

Rocks that show contorted original layers have the same microtextures as the layered rocks without relict textures, and are cut by similar irregular pegmatitic masses. Deformed plagioclase grains are found in all facies of the rocks. Apparently complete fluidity was not attained by any large segment of rocks. The significantly larger percentage of microcline in rheomorphic quartz monzonite gneiss and the postdeformation crystallization of microcline and quartz, however, indicate that the mobile rocks were at least lubricated by alkalic solutions, and the material surrounding the plagioclase grains may have closely approached a melt.

Penetrative intergranular movement in the presence of alkalic solutions, followed by recrystallization, converted the originally banded quartz monzonite gneiss into a more uniform, alaskitic rock with more abundant microcline and minor amounts of biotite. Where hornblende gneiss was subjected to penetrative movement, much of the hornblende was destroyed, the plagioclase was converted to a more sodic feldspar, and the rock was irregularly permeated by alkalic and silicic solutions. The hormblende gneiss that was not sheared out but was dragged along passively, recrystallized somewhat but did not change composition greatly. The sharp discontinuities between relatively even textured layers, which range from very similar compositions to markedly different compositions, indicate that much of the movement in the mobile rock took place by shear between the layers. Apparently movement was that of a very plastic solid or an extremely viscous fluid in which the layers retained their compositional identities.

\section{DIRECTION OF MOVEMENT}

In determining the direction of flow, much hinges on the question of how the orientation of structures at the present time compares with the orientation at the time of origin. This is difficult to answer as it is impossible even to determine the extent or direction of Laramide deformation within the pre-Cambrian rocks, without considering the long periods for which we have no record. There is no petrographic evidence, however, for a period of metamorphism later than that during which the rocks in the gneiss complex were formed, and the regional trend of foliation and lineation in the gneiss complex are uniform. Most local deviations in the attitude of foliation occur in the vicinity of crests and troughs of folds. Evidence for local deformation was seen only along large Laramide faults, and involved cataclasis rather than flexure.
That large-scale tilting, folding, or inversion took place seems unlikely from a consideration of the zonal distribution of the different rock types. Large masses of quartz monzonite gneiss occur in the northern and southern parts of the district, and each of these masses shows evidence that some of the rock became mobile subsequent to transformation. These two masses reached about the same stage in formation at the time of origin, and presumably might have been at comparable depths. Pegmatite and biotite-garnet gneiss bodies are abundant through the central part of the district in a zone peripheral to the large bodies of quartz monzonite gneiss, and this zone may have been downwarped. This suggestion, however, is not borne out by any systematic variation in attitude of foliation through the district. Although pegmatite and biotitegarnet gneiss are not uniformly distributed, they both occur throughout the zone, so presumably there has been no strong east-west tilting. Although not conclusive, these considerations suggest that the present vertical coordinate through the rheomorphic rook was not far from vertical at the time of metamorphism and mobilization.

The annular layers of the funnel-shaped masi could arise most easily by differential movement either around or in the direction of the axis of the funnel. Evidence that the rocks in the annular structure were more plastic than the surrounding rocks at the time of deformation (see "Condition of rocks") makes it difficult to understand how rotational morement could account for the features shown. If the funnelshaped structure had been a mass of mobile rock that intruded and shoved aside the adjacent rocks by movement in the direction of the axis, the differential movement due to frictional drag on the walls would have been distributed through much more of the mass than if the structure had been a rotating resistant body. In a mobile mass the greatest differential movement would have taken place along the flanks where the most prominent layering and best formed new textures now occur, and movement of the mobile rock would be limited only by the physical conditior of the intruded rocks.

It seems necessary to postulate amount of morement in terms of at least several thousands of feet to account for the discordant relationship of the annular structure and the orientation of hornblende gneiss inclusions parallel to the rheomorphic layering and locally athwart the regional trends. The funnel shape and the general appearance of the mass, indicative of a foreign body that shoved aside the preexistent rocks, implies a rootless body of mobile rock which has the greater part of the body above the levels now exposed. 


\section{CAUSe OF MOVkMent}

It seems plausible that the movement was governed largely by gravity. Quartz monzonite gneiss is much less dense than hornblende gneiss, and if large enough masses of the lighter rock became mobile under the influence of high temperature and abundant solutions in the pores, the buoyant force would exceed the strength of the surrounding rocks and the mobile rock would rise. Movement in the direction of the axis of the annular structure would be subparallel to the tectonic axis as shown by the lineation of fold axes in regionally and dynamically metamorphosed rock and thus about at right angles to the direction commonly inferred for regional tectonic transport. The regional stress field that persisted through the complex sequence of metamorphism in the district could hardly account for movement of this type.

TABLE 1.-Approximate specific gravities of pre-Cambrian rocks from the Northgate district, Colorado

\begin{tabular}{|c|c|c|}
\hline Rock & $\begin{array}{l}\text { Specific } \\
\text { gravity }\end{array}$ & $\begin{array}{c}\text { Specimens } \\
\text { measured }\end{array}$ \\
\hline Hornblende gneiss. & 2. $95-3.00$ & 3 \\
\hline Quartz monzonite gneiss & 2. $61-2.63$ & 3 \\
\hline Biotite-garnet gneiss & 2. $80-2.85$ & 2 \\
\hline Pegmatite & 2. $58-2.59$ & 2 \\
\hline Hornblende-biotite gneiss & 2. 80-2. 82 & 2 \\
\hline Mylonite gneiss & 2. $68-2.78$ & 2 \\
\hline Rheomorphic quartz monzonite gneiss & 2. 64 & 2 \\
\hline Intrusive quartz monzonite & 2. $61-2.63$ & 3 \\
\hline
\end{tabular}

The specific gravity of typical specimens of most preCambrian rock types in the district was determined (table 1), and the average of the rocks in several parts of the district was approximated. The specific gravity of biotite-bearing rheomorphic quartz monzonite is about 2.64, the average for the rocks cropping out in a strip of gneiss complex a mile wide along the south margin of the large mass of quartz monzonite gneiss that includes the once mobile rocks is about 2.76 , and the average for rocks in a large block of gneiss complex south of this strip is about 2.80 . The average specific gravity of rocks in that part of the gneiss complex lying between the large mass of quartz monzonite gneiss in the northwest part of the district and the stock of intrusive quartz monzonite (pl. 48) is near 2.78.

These comparative figures represent only the order of magnitude of the differences during mobilization. Variations due to elevated temperature and pressure are not considered, and more importantly the effect of solutions in the pores is not shown. If, as seems likely, intergranular alkalic solutions were abundant in the mobile rock, they would have lowered the specific gravity of that rock significantly. A comparison of the specific gravity of adjacent blocks of rocks now exposed considers only part of the environment at the time of rheomorphism; the buoyant force of the mobile rocks depended as well on the specific gravity of th a overlying rocks. Metasomatism was zonal, and transformation probably decreased upward. The hydrostatic pressure of the cooler and presumably more dens? overlying rocks would provide a powerful mechanism to force the lighter, mobile rocks upward.

\section{DACITE PORPHYRY}

\section{GENERAL FEATURES AND DISTRIBUT"ON}

A very fine grained, medium- to dark-gray porphyritic rock occurs in several northwerd-trending dikes near the lower end of Camp Creek ( $\left.p^{\top} .48\right)$. The rock is extremely hard and resistant to weathering and crops out in many places. The dikes are nearly vertical and as much as 5 feet thick and 3,200 feet long. Most dikes end in hornblende gneiss. No offset of the walls was detected across any of the dikes, and no fractures or groups of fractures were discerned along the strike. Apparently they were injected into tension fissures.

The dikes trend nearly at right angles to the strike of foliation of the gneiss complex and in the s'me general direction as the plunge of fold axes in the metamorphic rocks. Evidently the tension fissures along which the dikes were injected were not related to the original deformation plan of the gneiss complex. Similar small dikes are found in xenoliths in the intrusive quartz monzonite stock south of the lower part of Camp Creek; these are definitely older than the enclosing granitic rock. The dikes are thus intermediate in age between the rocks in the earlier pre-Cambrian gneiss complex and the later intrusive quartz monzonite and may be unrelated to either.

\section{PETROGRAPHY}

The dacite porphyry typically is composed of 40 to 50 percent sodic ardesine, 15 to 20 percent green biotite, 20 to 25 percent quartz, 10 to 15 percent orthoclase, and 5 percent epidote. Apatite and magnetite are relatively abundant minor accassory minerals. Andesine occurs as idiomorphic phenocrysts as much as 1.5 millimeters long and as sriall, lathlike crystals in the fine groundmass. Biotite occurs in irregular plates and generally is evenly distributed throughout the rock. A few ragged poikilitic hornblende phenocrysts as much as 1 millimeter in diameter are found in some dikes. Quartz and ortl oclase form a fine mosaic interstitial to the other major constituents. Epidote is secondary. The crystals in the 
groundmass generally are 0.3 millimeter or less in diameter.

\section{INTRUSIVE QUARTZ MONZONITE}

GENERAL FEATURES AND DISTRIBUTION

Quartz monzonite forms a stock and associated dikes in the central part of the Northgate district and several related dikes near the northeastern part of the mapped area. Although the relief is not great, the area of the stock is extremely rough. Weathering and erosion of the relatively coarse grained and jointed rock have reduced the surface to a rugged area of rounded pinnacles and boulders, cliffs, and benchlike flat areas. Very little soil or talus is present. The main body of the stock passes eastward into a complex of dikes that cuts the older gneisses on Pinkham Mountain. Although the broad summit of Pinkham Mountain is relatively flat and is covered by a heavy pine forest and a thick mantle of weathered rock, the quartz monzonite is more resistant to weathering than the surrounding gneiss, so the dikes tend to stand up as low outcrops.

Reconnaissance off the area mapped, near the Colorado-Wyoming State line, showed that a large mass of similar granitic rock extends from a point about a mile east of the Northgate district for about 6 miles eastward to near the Laramie River, where it is covered by younger sedimentary rocks. The western margin of this body is crosscutting and sharp and shows little evidence of contact metamorphism. A similar large granitic mass occurs in the central part of the Park Range, 20 to 25 miles southwest of the Northgate district. Thin sections of specimens collected along Boswell Creek, about 2 miles east of the Northgate district, and near Rainbow Lake in the Park Range were studied for comparison. Both of these specimens strongly resemble that in the Northgate district, and the stock in the Northgate district appears to be but one of many similar granitic masses that occur in the pre-Cambrian of northern Colorado and southern Wyoming.

This rock closely fits the descriptions given by Blackwelder (1908, p. 787-788; and in Darton and others, 1910, p. 5) for the Sherman granite in the Laramie and Sherman quadrangles $15-30$ miles to the northeast, and therefore in the two preliminary reports published on the Northgate district (Steven, 1953 ; 1954) it was called Sherman granite. However, Harrison, ${ }^{5}$ working in the type locality of the Sherman granite, described field relations that strongly support

\footnotetext{
Harrison, J. E., 1951, Relationship between structure and mineralogy of the Sherman granite, southern part of the Laramie Range, W yoming-Colorado: Unpublished thesis, Univ. Illinois.
}

his contention that the Sherman granite there originated through metasomatism. Thus the earlier corralation of the intrusive quartz monzonite in the Northgate district with the Sherman granite may not have been correct, and it now seems more appropriate not to apply a proper name to the rock until more regional work is done to establish the proper correlatiors.

\section{LTTHOLOGY}

The main body of the stock is made up large'y of a medium- to coarse-grained, somewhat porphyritis rock. Rectangular pink microcline phenocrysts half an inch or more long are set in a variable groundmass $c f$ pink microcline, white plagioclase, and glassy quartz. Biotite varies widely in abundance; in places it makes up nearly 10 percent of the rock and elsewhere is entirely absent. The texture and grain size of the quartz monzonite vary widely, not only between the stock and the associated dikes but also within each body, and significant quantities of relatively fine grained, distinctly porphyritic quartz monzonite also occur. On weathered surfaces the rock appears dull gray to brown, but the fresh exposures are mottled pirk and gray.

The rock in some of the larger dikes and irregular masses on Pinkham Mountain resembles that in the central part of the stock, but most of the rock in the dikes, and some near the margin of the main kody is fine to medium grained and appears distinctly aplitic. Biotite is a minor constituent in most of the rock in the peripheral zones, and the quartz and feldspar form an aggregate of anhedral grains containing scattered larger crystals of microcline and quartz. Tha rock contains a few well-formed microcline phenorrysts; most of the larger grains are irregular in shape. Small masses of fine-grained pegmatite are common in some dikes, and all gradations exist between these and the surrounding alplitic rock.

Fine-grained porphyritic quartz monzonite occurs in several dikes and small masses northeast of the stock and near the east edge of the district. The dikes range from less than a foot thick and several tens of feet long to nearly 75 feet thick and more than 3,000 feet long. Larger bodies are slightly coarser grained than the small bodies. Many of these dikes are too small to be shown on the geologic map (pl. 48). The phenocrysts in these dikes are plagioclase, whereas those in the stock are microcline, and are set in a very fine grained pinkish-gray groundmass of quartz, feldspar, and biotite.

\section{PETROGRAPHY}

Two generations of minerals are generally present in the intrusive quartz monzonite. Ragged biotite and lath-shaped plagioclase crystals comprive the 
older generation, and these grains are widely broken and deformed on a minor scale. The younger generation of minerals consists of irregular plagioclase grains, irregular to rectangular microcline-perthite grains, and irregular to rounded quartz grains and aggregates. The younger mineral grains are not deformed, and they complexly embay the older crystals.

\section{MAIN BODY OF THE STOCK}

Typical rock in the main body of the stock is medium to coarse grained and is composed of about 5 percent biotite, 30 to 35 percent plagioclase, 30 to 35 percent microcline-perthite, and 30 percent quartz. Zircon, apatite, and fluorite comprise the minor accessory minerals. Depending on the quantity of microcline, the stock ranges in composition from the more common quartz monzonite to granodiorite or to granite. Locally rocks vary greatly in composition, and in these rocks either quartz, microcline, or plagioclase may greatly predominate.

The plagioclase composition ranges from $\mathrm{An}_{5}$ to $\mathrm{An}_{17}$, but in most of the rock it is sodic oligoclase. It occurs in corroded laths as much as 4 millimeters long, and in irregular, untwinned grains that in part replace the lath-shaped plagioclase crystals. Many of the lathshaped plagioclase crystals are deformed, and much of the polysynthetic twinning was partly or completely destroyed during the deformation and later alteration. A hazy or "ghost" twinning still can be recognized in many of these crystals. The cores of some of the laths are crowded with fine sericite and very fine grained saussuritic inclusions; the arrangement of these inclusions in some crystals indicates that the plagioclase originally was appreciably more calcic in composition and may have been zoned. The irregular and untwinned plagioclase grains are not deformed; they evidently formed by recrystallization after cataclasis. These grains generally have about the same composition as the earlier, deformed crystals adjoining them, and the sericite and saussuritic inclusions in the recrystallized plagioclase are in patches rather than zones. Clear borders are common in all plagioclase crystals, and the cores of many grains have in part been cleared of the inclusions.

Microcline-perthite forms irregular to nearly rectangular phenocrysts and smaller, irregular grains in the groundmass. Much of it embays the deformed plagioclase (pls. $54 F, 55 A, B$ ) and biotite and commonly contains abundant inclusions of them. Microcline is not deformed and it definitely crystallized after the brecciation of the early plagioclase and biotite. The age relationship between microcline and recrystallized plagioclase is not so definite, and the two minerals commonly appear about contemporaneous.
Myrmekite is widespread along the contacts between plagioclase and microcline grains. It occurs as rounded growths embaying microcline, as border zones on both relict and recrystallized plagioclase crystals, and as irregular growths within some deformed plagioclase crystals. The plagioclase in myrmekite commonly is slightly more sodic than the associated oligoclase or albite.

Irregular grains and aggregates of quartz embay the relict plagioclase and biotite crystals and arnear to have been introduced both contemporaneously with and slightly later than the microcline. Some of the quartz aggregates are comparable in size to the microcline phenocrysts, but generally they are smaller. In places abundant irregular to rounded grains of quartz embay all other constituents of the rock. This relatively late quartz is common near the margin of the stock or in the adjacent dikes but is not restricted to these occurrences. All the quartz shows wavy extinction, but this could have been produced much later than the time of introduction.

Small, ragged crystals of green biotite scattered throughout the rock in places form as much as 10 percent of the rock, but locally they are entirely absent. Many of the grains are deformed and broken and most are embayed and corroded by undeformed microcline and quartz. Biotite commonly contains inclusions of magnetite, and in many places has been altered in part to a mixture of sericite, chlorite, and magnetite. Secondary epidote also is common.

One small area near the center of the stock is particularly significant as it contains no microcline. The plagioclase here is sodic albite $\left(\mathrm{An}_{3-5}\right)$, and is associated with considerable quartz, and some idiomorphic epidote. Albite makes up nearly 70 percent of tr rock, and more than half of this quantity has recrrstallized as undeformed grains that range from small, irregular crystals to rectangular phenocrysts more than half an inch in length. The remainder of the alkite occurs in pseudomorphic laths, most of which show marked effects of deformation. These latter grains are abundant and preserve some of the texture of the rock $\left(F^{1} .55 C\right)$ that existed before recrystallization. The rest of the rock consists of 20 to 25 percent quartz with replacement relations, and 5 to 10 percent irregular to idiomorphic epidote. The relict texture shows that plagioclase was one of the major constituents of the original rock and that quartz and microcline either were lacking or were present in subordinate amounts. The original ferromagnesian minerals were completely destroyed.

\section{MARGINAL DIKES}

The composition of the rocks in the complex of dikes on Pinkham Mountain differs significantl 7 from that 
in the interior of the stock. Quartz, microcline, and plagioclase are generally present in nearly the same proportions as in the main body of the stock. However, biotite is much less abundant here, and the average plagioclase is calcic albite in contrast to the common sodic oligoclase found in the main body of the stock.

Biotite generally forms only minor wisps and shreds generally associated with different amounts of chlorite, sericite, and magnetite. In places these secondary minerals form crude pseudomorphs after biotite, but elsewhere they are disseminated through the rock. A trace of muscovite occurs in some dikes, but generally it is rare. Here and there several percent of biotite has survived the alteration, and in one specimen studied biotite made up about 8 percent of the rock.

In 10 specimens the composition of the plagioclase ranged from $A n_{3}$ to $A n_{14}$. Generally the composition ranges from $A n_{5}$ to $A n_{10}$. Plagioclase forms corroded and deformed pseudomorphic laths, as well as undeformed irregular grains that embay the earlier crystals. The broken grains originally had abundant polysynthetic twinning, but much of this was destroyed during deformation and subsequent recrystallization. The surviving twinning commonly is patchy or in hazy "ghosts" like that in the interior of the stock. The recrystallized plagioclase is untwinned and definitely replaces the earlier plagioclase; in a given area the composition of the plagioclase in both habits is essentially the same. The saussuritic and sericitic inclusions in the relict and recrystallized grains of plagioclase in the marginal dikes cluster into irregular patches separated by abundant relatively clear plagioclase. Clear rims are common, and some crystals are almost free of inclusions. In general the more sodic the plagioclase, the fewer the inclusions; some almost clear crystals of albite contain only sparse evenly distributed, saussuritic inclusions.

As in the central part of the stock, microclineperthite does not have a cataclastic texture, and it corrodes and replaces the deformed plagioclase laths. The larger microcline grains contain abundant relicts of the earlier minerals, many of which show common optical orientation. The phenocrysts in the marginal dikes are more irregular than those in the main body of the stock, though still nearly rectangular. The smaller grains are very irregular. The texture in the pegmatitic parts of the dikes results largely from coarse microcline crystals, which show the same replacement relations as those in the finer grained parts of the rock; the pegmatite texture thus was formed at the time when microcline was introduced.

Quartz apparently was the last important constituent to be introduced. Some appears to have formed about contemporaneously with the microcline, but other grains definitely embay the microcline. Some quartz occurs as irregular masses and rounded blebs and rods that apparently replace all the other minerals. In places a pseudographic texture formed, and one specimen from the core of Sentinal Mountain (pl. 55 D) shows that the quartz rods in adjacent microcline and albite grains have a common optical orientation.

In places where replacement by microcline vras less complete, some relict texture of the original rock can be seen. Bent and broken plagioclase laths of jandom orientation, now pseudomorphed by albite, show mutually interfering relations characteristic of a norma] granitic texture. Commonly recrystallized albite is present, but not enough to mask the original taxture.

\section{SATELIITIC DIKES}

The composition of the rock in the satellitis dikes near the east edge of the district is variable. As in the stock and associated marginal dikes, plagioclese and biotite appear to have been the original minerals of the rock. These were replaced in varying amounts by potash feldspar, more sodic plagioclase, and quartz. Generally plagioclase, potash feldspar, and quar ${ }^{\dagger} \mathrm{z}$ each make up about 25 to 35 percent and biotite 5 to 10 percent of the rock. The groundmass of these rocks is very fine grained; the phenocrysts are as much as 2 millimeters long. In contrast to the rock in the stock, the phenocrysts were original constituents of t] 9 rock and are plagioclase rather than microcline.

Plagioclase, both phenocrysts and in groundmass, is highly corroded, and much of the original twinning was destroyed. Commonly the crystals are crowded with saussuritic and sericitic inclusions, and the comrosition is difficult to determine. The original plaşioclase crystals were irregularly albitized, and in thin sections compositions range from near mid-oligoclase $\left(A \mathrm{n}_{15}\right)$ to calcic albite $\left(\mathrm{An}_{7}\right)$. Irregular, recrystallized plagioclase crystals which replace the early plagioclase laths are common, but they are generally not as abundant as in the stock or marginal dikes.

Plagioclase and biotite are corroded and replaced by a very fine grained aggregate of potash feldspar and quartz. Some quartz clearly embays microcline, but in much of the rock no age sequence could be determined for these two minerals. Many corroded plagioclase laths are surrounded by micrographic intercrowths of potash feldspar and quartz (pl. $55 E^{\prime}$ ), in plac s with the quartz rods arranged almost radially around the plagioclase cores. The thickness of the micrographic rims is related to the degree of replacement of the plagioclase. Where plagioclase laths still retain their form, the rims are thin; where the laths are highly corroded, the rims are thicker and much more irregular. 
In some places plagioclase is almost completely replaced by irregular, radial masses of micrographic quartz and potash feldspar.

The rela tively large dike in the eastern part of sec. 36 , in undivided T. 12 N., R. 79 W., is unusual in containing no potash feldspar. Relatively clear albite $\left(\mathrm{An}_{3-5}\right)$ makes up about 60 percent of the rock. Sericite inclusions are fairly abundant, but zoisite or clinozoisite inclusions are very minor. The albite is in laths with relict granitic texture and in irregular replacement grains of the same composition (pl. $55 \quad F)$. Some irregular to nearly rectangular albite crystals 2 to 3 millimeters long replace both the early laths and the smaller replacement grains of albite and enclose many residual inclusions. Biotite apparently once made up about 10 percent of the rock, but almost all of it has been altered to ragged aggregates of chlorite and magnetite. Irregular quartz grains comprise as much as 30 percent of the rock; they embay all the minerals except some late epidote. Epidote is very abundant in places but generally comprises only about 5 percent of the rock; it occurs in veinlets, random crystals, and granular aggregates. Although the plagioclase has been thoroughly albitized and in part recrystallized, much of the original texture of the rock can be seen. Apparently the original rock was a biotite diorite or quartz diorite.

\section{WALL-ROCK ALTERATION}

Contact alteration along the walls of the stock and the dikes has been slight, and rarely affected more than a few feet of the country rock. Hornblende gneiss was most readily altered, and it commonly is somewhat silicified and epidotized adjacent to the granite. Along many contacts, particularly where the wall rock is quartz monzonite gneiss or quartz- and biotite-bearing gneisses, no evidence of alteration was recognized in the field.

Thin sections from a suite of specimens collected across a contact of intrusive quartz monzonite and hornblende gneiss were studied. Essentially unaltered hornblende gneiss 10 feet or more from the contact consists of about equal amounts of andesine and hornblende, with as much as 5 percent biotite. Minor amounts of epidote occur as scattered granules. Adjacent to the contact, the rock has a cataclastic texture, and the original minerals have been somewhat altered. Hornblende was transformed in part to chlorite and epidote, biotite was altered to chlorite, and plagioclase was saussuritized and changed in composition to near $\mathbf{A n}_{20}$. Minor amounts of quartz and potash feldspar were introduced along fractures and cataclastic zones, and abundant epidote occurs in veinlets and scattered grains as well as with chlorite in pseudomorphs after hornblende.

\section{ORIGIN}

The sharp, essentially unaltered contacts, the markedly rectilinear pattern of the dikes which can be related in large part to directions of physical weakness in the wall rocks, and the finer grained rock in the peripheral zones of the stock and in outlying dikes all indicate a magmatic origin for the quartz monzonite in the Northgate district. The occurrence of plagioclase phenocrysts in the very fine grained, chilled satellitic dikes near the east margin of the mapped area, which contrast with the late microcline phenocrysts in the main body of the stock, and the remnants of normal granitic texture that can be clearly dated as older than the metasomatic introduction of microcline and quartz are convincing evidence.

The variation in texture and composition of the quartz monzonite apparently is related in lerge part to deuteric alteration. Plagioclase, biotite, and perhaps some quartz were the earliest minerals to crystallize from the magma, and they probably formet a dioritic or quartz dioritic rock. The rock was pervasively deformed after it was consolidated or nearly consolidated, and many biotite and plagioclase crystals were bent and broken. Silica- and alkali-bearing solutions permeated the broken rock, and the ear'y minerals were corroded and in part replaced by abundant microcline, quartz, and more sodic plagio lase. The intensity of the alteration varied throughout the stock and associated dikes, and the mineral tran formations show a crude zoning. Generally, the plagioclase is more sodic, and the biotite is largely altered to chlorite and sericite in the peripheral zones.

\section{EMPLACEMENT}

The magma from which the rock in the stock originally formed apparently was emplaced chief'y by means of magmatic stoping. The northern contact of the stock, for example, has many angular, steplike irregularities (pl. 48); and in one place a narrow cike projects from the main body of the stock parallel to a nearby section of the angular contact. In this place the dike was frozen while prying off a block from the wall of the stock. The extremely complex pattern of dikes on Pinkham Mountain displays all stages in the disruption of the roof over a stock. These dikes have sharp contacts against essentially unaltered wall rocks and show no evidence of a replacement origin.

The magma apparently penetrated fairly wide-spaced fractures in advance of most active stoping. These fissures, perhaps opened by the pressure of the rising column of magma, were irregularly enlarged by local stoping, permitting irregular masses of maşma to project into the fractured and veined roof. Continued stoping gradually engulfed the pendants and septa 
between these areas of more rapid stoping. Effects of this process are most clearly shown along the southern flank of Pinkham Mountain, where the rocks are well exposed. Narrow dikes with regular walls, perhaps representing fissures formed by local spreading, connect angular masses of granite which are fringed in part by a lacework of small dikes. Many of these small dikes completely surround blocks of country rock, and were actively intruding the shattered wall rocks and engulfing some blocks when cooling of the stock stopped the process.

It is difficult to determine which of the dikes or irregular masses of granite were emplaced along fractures opened by actual spreading of the roof of the magma chamber. Once stoping enlarged a single fracture or zone of fractures to any extent above the general top of the magma body, other fissures could open by the movement of blocks of country rock toward the already active zone of stoping, and no further dilation of the roof or walls of the magma chamber would be required.

The maximum spreading of a fracture that can reasonably be credited to the hydrostatic pressure of the magma is limited to the narrowest width across the fissure, and in most places this appears to have been relatively small. This is well illustrated by the irregular, generally northward-trending dike in secs. 9 and 16 , T. 11 N., R. 79 W., about a half mile east of the Fluorspar mine (pl. 48). This dike ranges from about 400 to 1,000 feet in thickness. Although the walls of the dike differ in detail, they appear to correspond and superficially the block of metamorphic rock to the west appears to have broken from the wall and roof of the magma chamber and to have drifted several hundred feet out into the magma. Near the northern margin of sec. 16, however, a projection of metamorphic rock comes within about 50 feet of bridging across the dike, so any drifting or forceful separation must have been small, and the broad dike more probably resulted from piecemeal stoping along an originally irregular fracture. The block of metamorphic rocks west of this dike displays the most extreme wall-rock fragmentation found near the stock, and has the aspect of a large-scale breccia cemented by dikes of quartz monzonite.

The magmatic stoping apparently was controlled by two general groups of fractures. Many of the smaller blocks pried from the roof and walls of the magma chamber broke along fractures, either nearly parallel to the foliation or at right angles to it. Small blocks in particular show this control, although several large masses also are bounded by these fractures. Most of the fissures formed along these directions of weakness are irregular and generally do not persist far. Thus the small-scale fracturing of the country rock and the piece- meal stoping by the magma appear to have been controlled largely by directions of weakness inherent in the wall rocks.

Another group of fractures trends eastward to southeastward about parallel to the elongation of the stock. These fractures control parts of the northern wall of the stock and are followed by most of the larger dikes that extend eastward from the main body of the stock toward the Baker Pit and the Camp Creek mine (pl. 48). They trend obliquely to the foliation in the gneiss complex, and most have relatively smooth and regular walls. The fissures followed by these dikes are not related to known directions of weakness in the wall rocks, and are much more regular and persistent tha $n$ those following the foliation or related fractures. Tr ay may well have originated in the initial fracturing and spreading of the roof of the magma chamber by the hydrostatic pressure of the rising column of magma. The more abundant but smaller scale fissuring along foliation thus may have resulted from the detailed brecciation of a roof already stretched and broken along eastward- to southeastward-trending master fissures.

Despite the highly broken condition of the roof and walls of the stock, and the evidence of magmatic stoping, the main body of the stock is almost free of xenoliths. As wall-rock alteration is slight and the xenoliths that are found are very little alter?d, this lack of xenoliths cannot be due to assimilation. Rather it must have resulted from the sinking of the blocks to levels below those now exposed. To accomplish this removal of xenoliths below a zone of very active stoping, the sinking must have been rapid as there is no concentration of xenoliths near the periphery of the stock. Along the northern margin of the stock, the quartz monzonite is relatively free of xenoliths as far as the contact, and even the irregular, larger bodies of quartz monzonite in the stoping area enclose few blocks of country rock. Many blocks of country rock c'o occur in the quartz monzonite, however, in the vicinity of the breccialike aggregate of metamorphic blocks and granitic dikes near the Fluorspar mine where stoping was most active, and the mine workings show abundant xenoliths in quartz monzonite.

Rapid sinking of the blocks implies a large average size of the blocks, a significant difference in density between the xenoliths and the melt, or a relatively low viscosity for the magma. Abundant evidence for piecemeal stoping indicates that the average stope blocks were relatively small so the fragment size probably was not an important factor in clearing the exposed quartz monzonite of inclusions. The rocks in the gneiss complex include such varied types as quartz monzonite gneiss, pegmatite, hornblende gneiss, hornblende-biotite gneiss, and mylonite gneiss. Of 
these, the hornblende-bearing metamorphic rocks have relatively high specific gravity, but other rocks, such as quartz monzonite gneiss and pegmatite, are not significantly different from the quartz monzonite now found in the stock (table 1). The specific gravity of the original melt probably was lower than that of the rock now found in the stock, but the difference may not have been as great as might be expected, as petrographic evidence indicates that rock that first crystallized may have been dioritic in composition. Even so, the few xenoliths that are found show no selective accumulation of the lighter rocks. Thus, by elimination, the magma appears to have had a relatively low viscosity. Positive evidence for the low viscosity is the ease with which stoping was accomplished along relatively narrow fissures. It is difficult to imagine a viscous melt penetrating the wall rocks in as intricate a manner and in as small dikes as it did on Pinkham Mountain and permitting the blocks so loosened to sink easily to great depths.

\section{ORIGINAL ROCK}

Deformation and cataclasis of the early minerals could have taken place only after complete or nearly complete consolidation of the magma. No unaltered remnant of the original rock has been found, but several lines of evidence indicate that it probably was dioritic or quartz dioritic.

Biotite and lath-shaped plagioclase crystals are the only minerals that clearly show brecciation. Microcline, where not broken by later, unrelated movements is not deformed and everywhere is corrosive toward deformed biotite and plagioclase. Irregular, recrystallized plagioclase grains of about the same age as the microcline also are not deformed and clearly replace the earlier crystals. Most of the quartz was introduced at about the same time or even a little later than microcline. Under the microscope, almost all quartz shows the wavy extinction generally attributed to strain; so evidence of deformation cannot be used to establish the presence or absence of an earlier generation of quartz. A former interstitial habit of early quartz could easily have been masked by quartz introduced later.

In the central part of the stock where albitization was least intense, many of the relict plagioclase laths contain zonally arranged saussuritic inclusions of zoisite or clinozoisite and sericite. These probably were inherited from an original zoned and more calcic feldspar. As the inclusions commonly are somewhat disrupted and clear rims of plagioclase grains are common, it is probable that even here albitization involved some introduced material and was not merely saussuritic alteration. This is further suggested by the progressive disruption and decrease in abundance of saussuritic inclusions with an increase in albite content of plagioclase. Thus the original plagioclase probably was significantly more calcic than the sodic oligoclase or calcic albite now found.

Relict granitic texture still persists in some of the marginal and satellitic dikes and in local areas in the stock where less microcline was introduced. Although considerable albitization and recrystallization of plagioclase and alteration of biotite took place during alteration, enough relict texture is preserved to ir dicate that biotite probably made up 10 percent or nore of the original rock and that plagioclase constituted much of the remainder.

\section{DEUTERIC ALTERATTON}

Alteration of the original igneous rock produced a crude zoning of transformation products, which is shown best by the degree of albitization of plagioclase and alteration of biotite. In the main body of the stock, most of the plagioclase is sodic oligo lase which generally contains abundant saussuritic inclusions. Biotite, although considerably corroded, is still fairly well preserved and has only a minor amount of associated chlorite, sericite, and magnetite. Large rectangular phenocrysts of microcline are common. In the marginal dikes the plagioclase generally is more thoroughly albitized and in places is highly sodic albite; the abundance of saussuritic inclusions decreases with an increase in degree of albitization. Very little biotite persists, as most of it was replaced by microcline and quartz or was converted to mixtures of soricite (and muscovite), chlorite, and magnetite. Microsline phenocrysts are not nearly as abundant here as in the main body of the stock. Although more variable, the rocks in the satellitic dikes to the east generally belong to the same zone as the rocks in the marginal dikes.

The zoning does not appear to be due to incomplete reaction. The plagioclase in the pseudomorphic laths and in the recrystallized grains has essentially the same composition in any given specimen, so at least the plagioclase apparently approached equilibriur ${ }^{\uparrow}$ with the altering solutions. Biotite in the main kady of the stock and the mixture of sericite, chlorite, and magnetite in the peripheral zones also probably approached equilibrium, as assemblages of biotite-oligo lase-quartz and chlorite-sericite-albite-quartz are common associations in regionally metamorphosed rocks wl ore approximate equilibrium commonly is postulated.

More probably the zoning resulted from differences in temperature or concentration of the altering solutions in the different parts of the stock and associated dikes. Experimental data indicate that, the contrasting mineral assemblages formed during regional 
metamorphism can result either from changes in bulk composition or from changes in temperature-pressure conditions (Yoder, 1952). Under otherwise similar conditions, oligoclase and biotite are formed at higher temperatures than are albite, chlorite, and sericite, so the zonal arrangement of these minerals, with the lower temperature assemblages in the peripheral zone, is what might be expected. On the other hand, the concentrations of the materials dissolved in the throughtraveling late magmatic solutions undoubtedly changed from place to place, so bulk compositional factors may have been important.

Little is known of what happened to the lime, magnesia, and iron removed from the replaced minerals. Some of the lime could have been fixed in the minor amounts of epidote which are relatively common in the dikes and near the walls of the stock, but most was removed in solution. Little could be held in saussuritic inclusions in plagioclase, as these inclusions decrease in abundance with an increase in degree of albitization. The chlorite and secondary magnetite occur chiefly in minor aggregates left from the dissociation of biotite, and represent only a small percentage of the magnesia and iron in the original rock. No concentrations of calcic or ferromagnesian secondary minerals were noted in the vicinity of the stock, but as the wall rocks carry abundant hornblende and intermediate plagioclase, it is impossible to trace the origin of the widely distributed secondary chlorite and epidote.

It is difficult to explain the relatively minor alteration of the wall rock around a body as intensely endomorphosed as the quartz monzonite stock in the Northgate district. Perhaps the drop in temperature of the deuteric solutions as they passed from the relatively hot mass of the stock into the cooler wall rock inhibited further reactions, but this hypothesis encounters difficulties when it is applied to the complex of dikes on Pinkham Mountain, where the dikes could hardly have been at significantly higher temperatures than the surrounding rocks.

\section{IATE MAGMATIC SOLUTIONS}

The solutions that caused alteration of the original rock probably originated at depth within the igneous body. An external source is unlikely as the wall rocks show only minor alteration adjacent to the intrusive contact, and in the stock the endomorphic alteration products are arranged in crude zones, with the higher temperature minerals nearer the center. Residual magmatic solutions of local origin conceivably might account for some of the alteration, but the volume of residual magma remaining after crystallization of the plagioclase could hardly account for the microcline which averages 35 percent of the rock and quartz which averages 30 percent. The zonal arrangement of the alteration products is consistent with the thesis that solutions of late magmatic origin moved upward and outward through the brecciated rock of the stock.

Some of the constituents in the solutions can be determined from the minerals introduced or transformed by them. Judging from the quantity of microcline and quartz that corrodes and replares the deformed plagioclase and biotite, potash anc' silica were important constituents of the solutions. Some quartz may have been original, but much of it was introduced during alteration.

The progressive albitization of plagioclase proves that soda was present in the solutions. Some albitization was undoubtedly merely saussuritic, but zoisite and sericite inclusions are most abundant in the main body of the stock, where the plagioclase is most calcis, and they are almost entirely absent in some sodic aibite. In any individual specimen, however, the composition of plagioclase generally is independent of its content of saussuritic inclusions, and both relatively clear and heavily clouded grains have about the same composition. The general decrease in saussurite with increasing albite content is accompanied by a progressire disruption of the original zonal arrangement of the inclusions within individual crystals. Plagioclase crystals with zonally arranged inclusions are restricted to the main part of the stock, and even here tr oy are not abundant.

Potash apparently was more abundant than soda in the late magmatic solutions that invaded the stock and related dikes. O'Neill (1948, p. 167-180), in a series of experiments on the hydrothermal alteration of feldspars, showed that the substitution of potash for soda in albite is a revisible reaction controlled by the law of mass action. Thus about a third of the rock could have been replaced by microcline only if the concentration of potassium ions in the soluticn was significantly higher than that of sodium ions. Replacement of plagioclase by microcline would impoverish the solution in potassium ions; at the same time the sodium ion concentration would increase residually and from the replaced plagioclase. This may account in part for the increased albitization toward the peripheral parts of the stock. The presence of abundant microcline in the dikes and near the margins of the stock, however, indicates that even here the potassium ion concentration was high relative to sodium ion concentration. It has long been recognized that the residual liquid from the crystallization of a normal subalkaline magma is rich in alkalies, silica, and water; and Bowen (1928, p. 100) has shown that potash commonly increases relative to soda in the late differer tiates.

Experiments by Gruner (1944, p. 578-589) and 
O'Neill (1948, p. 167-180) indicate that the transformation of albite to potash feldspar and the albitization of plagioclase take place most readily in basic solutions and that alkali leaching takes place in acid solutions.

\section{SUMMARY AND CONCLUSIONS}

Rocks buried deep in geosynclinal belts undergoing orogeny are deformed and profoundly metamorphosed, and not uncommonly are transformed to an assemblage of rocks with a general granitic composition. The relative importance of metamorphic processes versus igneous processes in the formation of these granitic bodies is currently one of the most warmly debated subjects in geology.

Read $(1943,1944)$ has summarized the evolution of many of the ideas on the formation of these granite masses, particularly the ideas concerned with metamorphic origin. His comments on the views evolved during the early part of this century by many European workers, notably the French geologists Michel-Levy, Lacroix, and Termier, and the Fennoscandians Sederholm and Holmquist, are of interest as it is chiefly on the foundations laid by these men that many of the present-day theories of granitization are built. These geologists all believed that regional metamorphism, granitization, and remelting (anatexis and palingenesis) are integral parts of the same general process. Although they held widely different opinions as to the role of granitic magma in this process-chiefly whether it was the cause or the result of the transformationsa magma capable of movement and intrusion was a reality to them. To this degree at least they were in agreement with the more confirmed believers in the efficacy of magmatic differentiation and crystallization to explain the features displayed by granitic rocks.

Modern workers on granitic rocks have a bewildering diversity of ideas regarding their origin, and there is a tendency on the part of some toward restrictive "schools of thought." The chief cleavage concerns the role, or even the necessity, of magma in the origin of granites. The present writer strongly agrees with Read (1948, p. $2 ; 1951$, p. 1) that the answer to this question is to be found in field work, and the descriptions and interpretations in this report are intended to record some basic data that may contribute toward the eventual solution of some of the problems of granitic rocks. No extensive review of the literature is made here, and only reports of particular application are cited.

The two groups of granitic rocks in the Northgate district - the intrusive quartz monzonite and the quartz monzonite gneiss - differ so widely that they probably are completely unrelated and their association in space is fortuitous. It is possible, however, that the two contrasting types represent an early stage and a late stage in the general process through which granitic rocks form. The progressive dynamothermal metamorphism, granitization, and rheomorphism described for the rocks in the gneiss complex may well mark the successive steps in the formation of a granitic magmaa series of events which locally proceeded just beyond the stage of incipient melting. The int usive quartz monzonite, on the contrary, originated through the consolidation of a liquid, a magma, which had risen high enough in the earth's crust so that much evidence of its origin was lost. At the levels now exposed it moved upward chiefly by means of magmatic stoping. Although the intrusive quartz monzonite shows ample evidence of alkali and silica metasomatisn, this alteration can reasonably be ascribed to the deuteric action of late alkalic and silicic solutions residual from normal magmatic differentiation.

Not only are the rocks in the roots of an orogenic belt subjected to the extra heat from the work expended during deformation, but also to the elevated temperature and pressure of the deeper levels cf the earth's crust to which they are depressed. High-grade metamorphic and migmatitic rocks attest to the increased chemical activity of the rocks under these conditions, and it seems a natural conclusion that either partial or complete melting of sialic rocks can take place should temperatures become high enough for long enough periods. Daly (1933, p. 292-293) cites several examples of melting related to shallow intrusive rocks which had only limited quantities of heat arrailable; such conditions are less favorable for melting than are present in the roots of an orogen where the sialic rocks are already hot and apparently there is an ample source of additional heat. Eskola (1932, p. 473-474; 1933) has proposed that the rocks under these conditions are subject to differential anatexis, with the low-melting constituents being melted before the rest of the rock and squeezed out to form either a granitic magma or a granitic "ichor" which is capable of widespread metasomatism.

Granitization without the loss of coherence of the affected rocks must take place at temperatures lower than those required for liquification, and it appears logical that if the heating process is sufficiently slow, migmatizing reactions within the heated body of rock should precede the formation of any significant quantity of molten rock. Following Eskola (1932, 1933), the low-melting constituents, the alkalies. silica, and volatiles, of the rocks in the roots of the o"ogen should become chemically active and mobile before the rest of the rock. As long as the quantity of such mobile material at any one place remains small, the rock should retain its physical continuity, and the chemical 
reactions involving the perineating inobile fraction should be of the "granitizing" variety. As the proportion of mobile inaterial increases, however, the rock should at solne time lose its coherence and becoine rheomorphic. These changes should be expected not only in the zone of differential anatexis, but also in the overlying rocks into which the nobile inaterial has migrated-or been squeezed, to use Eskola's phraseology -where relatively high concentrations can be built up by a continuing supply from below.

Weginann (1930, p. 58-75) has postulated that when rocks reach a rheoinorphic condition, they move by diapir injection, and includes within this process both maginatic and nonınaginatic moveinents. Most exponents of granitization apparently agree that a stage of plastic flow can be reached, but some of thein seem hesitant to inake what seems like the next logical assumption-a slightly higher temperature acting for a somewhat longer time should result in significant remelting so that the entire mass can act essentially as a liquid. Depending on the local stress conditions, a nass of rock conceivably can move while the quantity of intergranular liquid is still quite small (Sosinan, 1948, p. 116); conversely, a relatively large percentage of the mass inight have to beconne liquid before sufficient driving force or pressure is attained for it to breach the surrounding rocks.

The inechanisms outlined above are not original; they are essentially the same as those suinmarized by Waters (1948, p. 107-108) who stated, "The picture I have tried to present . . . is a prejudice that is by no ineans new. It is essentially the same process advocated by Michel-Levy, Eskola, Barrell, Sederholın, Lawson, and inany others." Turner and Verhoogen $(1951$, p. 305$)$ in sumnarizing their chapter on the granite-granodiorite plutonic association find,

If the extreme hypothesis of granitization by solid diffusion . . . is excluded, we find a suprising unanimity of opinion in recent writings on the general course of origin and evolution of granitic magmas . . . By all of these writers [Raguin, Eskola, Backlund, Wegmann, Reinhard, Niggli, MacGregor and Wilson, Read, Holmes, Bowen, and others] genesis of granitic magma . . . is attributed to differential fusion of mixed rocks in the continental basements.

It is my inpression that this "unanimity of opinion" is one of degree only, but nonetheless there appears to be a considerable field of coinınon thought.

\section{GRANITIC ROCKS IN THE GNEISS COMPLEX}

Before any conclusions can be reached on the general significance of the various transformations described for the rocks in the gneiss complex in the Northgate district, the origin of the transforming solutions inust be considered. They may have been derived, as the writer believes, from the differential anatexis of sialic rocks, or they nay have originated through crystallization of a granitic inass at depth, a nass which is nowhere exposed in or near the Northgate district.

No direct evidence is known that would favor a magmatic source for the granitizing solutions. Reconnaissance in parts of the Medicine Bow Mountains adjacent to the Northgate district showed that miginatitic rocks are widespread, but all of the granitic masses that appeared to be of magmatic origin were clearly younger.

Blackwelder (in Darton and others, 1910), in his discussion of the pre-Cambrian rocks in the I and Sherman quadrangles to the northeast, describes a granite gneiss with field relations apparently quite similar to those of the quartz inonzonite gneis? in the Northgate district. Blackwelder considered the granite gneiss to be a inildly metannorphosed granite of inagmatic origin. But whether this granitic gneiss is magmatic or migmatitic in origin, it occurs in relatively sinall, irregular bodies rather than in large subjacent masses, and thus seems a relatively unlikely source for widespread granitizing solutions.

Sinilar pre-Cambrian rocks were described by Spencer (1904, p. 37-41) froin the Encainpment district, Wyoming. Spencer reported two groups of granitic rocks-an older, soinewhat gneissose quartz diorite which he described as being "metannorphoser," and a younger, variable but generally coarse-grained red granite which is essentially unaltered. Both of these rock types are reported as "intrusive" into a hornblende schist formation, and are older than a considerably deforined metasedimentary formation. Correlations involving these kinds of rocks are hazardous at best, and it would be difficult without ad ditional detailed field work to say whether or not one or the other of these granitic rocks inight have been the source of granitizing solutions of great regional extent. It is significant, however, that Spencer described no migmatitic rocks in the Encampment area, and if any are present they inust have been included with one or the other of his granitic types.

The behavior of the masses of quartz inonzonite gneiss in the Northgate district which becaine inobile suggests that the causal forces were local and selfcontained and the inovement was in the nature of a diapir injection. Movement took place only in the larger masses of quartz monzonite gneiss, where the greatest softening might be expected under either hypothesis, but the annular flow structure in the northwest corner of the area is funnel-shaped downward, and seeins rootless. Were the granitization related to a inagmatic source below, such an apparently isolated mass of inobile rock would not be expected, 
but rather the rocks should have softened generally downward toward the source of energy.

The dynamothermally metamorphosed hornblende gneiss, which before metasomatism was the predominant rock type in the district, is relatively deficient alkalies and silica, and even under the differential anatexis hypothesis it is necessary to seek an outside source for the granitizing material. The hornblende gneiss was derived from a layered rock, however, and originally it must have been laid down under surface or near-surface conditions, whether as an accumulation of volcanic material or as impure carbonate sedimentary strata. Being geographically well within continental limits, such surficial rocks quite likely would have been underlain at some depth by a basement of more typically sialic rocks, which would be considerably more susceptible to partial melting under the conditions present in the roots of an orogen.

\section{GRANITIC ROCKS OF MAGMATIC ORIGIN}

The contrast in physical behavior of the rocks in the gneiss complex at the time of the progressive regional metamorphism, metasomatism, and mobilization as compared to their behavior at the times of the intrusion of the dacite porphyry dikes and the quartz monzonite stock and associated dikes, indicates that considerably different depths in the earth's crust were involved. The earlier sequence of events clearly took place deep in the zone where rocks behave plastically in response to deforming forces. The same rocks, however, responded to the stresses attendant to the later igneous intrusion by fracturing, and behaved strictly as brittle solids. In addition, the rocks were cool enough during these later periods to chill the relatively narrow dacite dikes so that they are made up of a typically dense, fine-grained rock. Although the quartz monzonite in the stock owes much of its present texture to deuteric reaction, it locally shows a significant decrease in grain size toward the margins, and many of the small satellitic dikes near the east edge of the mapped area are typically fine grained and were originally porphyritic, again pointing toward relatively rapid cooling.

Thus the intrusive magma rose high above the levels at which it originated, and invaded a relatively cool environment where the rocks were brittle and easily fractured. Chilling of the magma at these levels apparently was too rapid to permit soaking and migmatization of the adjacent country rocks by magmatic fluids, which so profoundly endomorphosed the intrusive mass. Thus the contacts are sharp and the intrusive character of the stock is clear cut.

\section{LITERATURE CITED}

Adams, F. D., and Barlow, A. E., 1910, Geology of the Haliburton and Bancroft areas, Province of Ontario: Geol. Survey Canada Mem. 6, 419 p.

Ball, S. H., 1906, Pre-Cambrian rocks of the Georretown quadrangle, Colorado: Am. Jour. Sci., 4th ser., v. 21, p. 371-389.

Beekly, A. L., 1915, Geology and coal resources of North Park, Colo.: U. S. Geol. Survey Bull. 596.

Blackwelder, Eliot, 1908, Pre-Cambrian rocks in southeastern Wyoming: Science, v. 27, p. 787-788.

Bowen, N. L., 1928, The evolution of the igneous rocks: 332 p., Princeton, N. J., Princeton Univ. Press.

Buddington, A. F., 1939, Adirondack igneous rosks and their metamorphism: Geol. Soc. America Mem. 7., ¿54 p.

Buddington, A. F., and Leonard, B. F., 1953, Chemical petrology and mineralogy of hornblendes in northwes: Adirondack granitic rocks: Am. Mineralogist, v. 38, nos. 11 and 12, p. 891-902.

Burchard, E. F., 1933, Fluorspar deposits in western United States: Am. Inst. Min. Met. Eng. Tech. Pub. 500, 26 p.

Cox, D. C., 1945, General features of Colorado fluorznar deposits: Colo. Sci. Soc. Proc., v. 14, no. 6, p. 263-285.

Daly, R. A., 1933, Igneous rocks and the depths of the earth: 598 p., New York, McGraw-Hill Book Co., In?.

Darton, N. H., Blackwelder, Eliot, and Siebenthal. C. E., 1910, Description of the Laramie and Sherman quadrangles, Wyoming: U. S. Geol. Survey Geol. Atlas, fol'o 173.

Eskola, P., 1932, On the origin of granitic magmis: Mineralogische and Petrographische Mitteilungen 42, p. 455-481.

1933, On the differential anatexis of rocks: Bulletin de la Commission Geologique de Finlande no. 103, VII, p. 12-25.

Goldring, E. D., 1942, An occurrence of ilsemanite: Am. Mineralogist, v. 27, no. 10, p. 717-719.

Gruner, J. W., 1944, The hydrothermal alteratior of feldspars in acid solutions between $300^{\circ}$ and $400^{\circ}$ C.: Econ. Geology, v. 39 , no. 8 , p. $578-589$.

Hague, Arnold, 1877, North Park, Park Range, in Hague, Arnold, and Emmons, S. F., Descriptive geology, U. S. geological exploration of the fortieth parallel (King): Prof. Papers Eng. Dept. U. S. Army, no. 18, v. 2, p. 94-141.

Ladoo, R. B., 1923, Fluorspar mining in the wistern states: U. S. Bur. Mines Rept. Inv. 2480.

1927, Fluorspar; its mining, milling, and utilization: U. S. Bur. Mines Bull. 244, 185 p.

Lovering, T. S., 1935, Geology and ore deposits of the Montezuma quadrangle, Colorado: U. S. Geol. Survey Prof. Paper 178.

Miller, J. C., 1934, Geology of the north and sou' $h$ McCallum anticlines, Jackson County, Colo., with special reference to petroleum and carbon dioxide: U. S. Geol. Survey Circ. 5.

O'Neill, T. F., 1948, The hydrothermal alteration of feldspars at $250^{\circ}$ to $400^{\circ}$ C.: Econ. Geology, v. 43, no. 3, p. 167-180.

Osborne, F. F., 1936, Petrology of the Shawinigan Falls district: Geol. Soc. America Bull., v. 47, no. 2, p. 197-227.

Read, H. H., 1943, 1944, Meditations on granite: Pt. 1, Geol. Assoc. London Proceedings, v. 54, pt. 2, p. (4-85. Pt. 2. ibid., v. 55, pt. 2, p. 45-93.

1948, Granites and granites, in Origin of granite: Geol. Soc. America Mem. 28, p. 1-19.

1951, Metamorphism and granitization: Geol. Soc. of South Africa, Alex. L. du Toit Memorial Lectures no. 2, 27 p. 
Reynolds, D. L., 1944, The southwestern end of the Newry igneous complex: Geol. Soc. London, Quart. Jour., v. 99 pt. 3-4, p. 205-246.

Sosman, R. B., 1948, Discussion, in Origin of granite: Geol. Soc. America Mem. 28, p. 116.

Spencer, A. C., 1904, The copper deposits of the Encampment district, Wyoming: U. S. Geol. Survey Prof. Paper 25.

Spurr, J. E., Garrey, G. H., and Ball, S. H., 1908, Economic geology of the Georgetown quadrangle, Colorado: U. S. Geol. Survey Prof. Paper 63.

Steven, T. A., 1953, Geology of the Northgate fluorspar district, Colorado: Wyo. Geol. Assoc. Guidebook, 8th Annual Field Conference, 1953.

1954, Geology of the Northgate fluorspar district, Colorado: U. S. Geol. Survey Mineral Inv. Map MF 13.

Turner, F. J., and Verhoogen, Jean, 1951, Igneous and metamorphic petrology; 602 p., New York, McGraw-Hill Book Co., Inc.
Warne, J. D., 1947, Northgate fluorspar, Jackson Count", Colo.: U. S. Bur. Mines Rept. Inv. 4106.

Waters, A. C., 1948, Discussion, in Origin of granite: Geol. Soc. America Mem. 28, p. 106-108.

Waters, A. C., and Campbell, C. D., 1935, Mylonites from the San Andreas fault zone: Am. Jour. Sci., 5th ser., v. 29, no. 174 , p. $473-503$.

Wegmann, C. E., 1930, Ubber Diapirismus (Besonders im Grundgebirge): Bull. de la Comm. Geologique de Finland? no. 92, III, p. 58-76.

1935, Zur deutung der Migmatite: Geologische Rundschau, Band 26, p. 305-350.

Yoder, H. S., Jr., 1952, The $\mathrm{MgO}-\mathrm{Al}_{2} \mathrm{O}_{3}-\mathrm{SiO}_{2}-\mathrm{H}_{2} \mathrm{O}$ sys ${ }^{+}$em and the related metamorphic facies: Am. Jour. Sci., Bowen volume, p. 569-627. 


\section{N D E X}

\begin{tabular}{|c|c|}
\hline Page & Yage \\
\hline Adirondack Mountains & Lithology, biotite-garnet gneiss. . \\
\hline Anatexis & hornblende-biotite gneiss \\
\hline Annular layers. & hornblende gneiss. \\
\hline r pit & intrusive quartz monzonite \\
\hline "Basic front"'............ & ite gneiss \\
\hline Bureau of Mines exploratory program & $\begin{array}{l}\text { pegmatite } \\
\text { quartz monzonite gneiss }\end{array}$ \\
\hline ....... 338, 364 & rheomorphic quartz monzonite gneiss..... \\
\hline Camp Creek mine & Lit-par-lit gneiss............. \\
\hline Colorado Geological Survey Board. . . . & \\
\hline Colorado Metal Mining Fund Board.... & $\begin{array}{l}\text { MeCallum anticlines. } \\
\text { Magmatic stoping }\end{array}$ \\
\hline Deuteric alteration. & Medicine Bow Mountains......... $335,336,337,355$ \\
\hline Diapir injection & Metasomatism \\
\hline Distribution, biotite-garnet gneiss. & Minerals, albite \\
\hline rphyry & sine \\
\hline e-biotite gneiss. ..... & apatite _....... $339,340,345,349,354,355,364,366$ \\
\hline hornblende gneiss. & augite \\
\hline intrusive quartz monzonite...... & biotite. \\
\hline mylonite gneiss & $344,349,351,353,354,355,360,361,364,366,367$ \\
\hline pegmatite & blue amphibole \\
\hline onzonite gneiss ............... & chlorite \\
\hline quartz monzonite gneiss..... & chrysotile \\
\hline Dynamic metamorphism & clinozoisite $\ldots \ldots$ \\
\hline rphism.... $338,340,345,372$ & epidote_. $340,344,345,349,351,354,355,364,366,368$ \\
\hline Fluorspar & 366 \\
\hline Fluorspar mine & $345,348,351,352,360$ \\
\hline Foliation, hornblende-biotite gneiss & ite \\
\hline 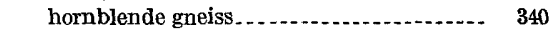 & nde $339,344,353,355,360,361,368$ \\
\hline mylonite gneiss & magnetite.... 340 , \\
\hline $357,359,363$ & $344,345,349,351,354,360,361,364,366$ \\
\hline Front Range, Colorado & $\begin{array}{l}\text { microcline } \\
\text { microcline-perthite. }\end{array}$ \\
\hline Gneiss complex..... & muscovite \\
\hline Grenville s & myrmekite $\ldots \ldots .351,360,366$ \\
\hline Idaho Springs formation & olivine. \\
\hline Independence Mountain fault. & orthoclase \\
\hline Jelm Mountain & $\begin{array}{c}\text { plagioclase } \_339,344,351,353,359,361,366,367,368 \\
\text { quartz } \\
\quad 344,349,351,353,354,355,360,361,364,366,367\end{array}$ \\
\hline $\mathbf{K}$ & sericite \\
\hline 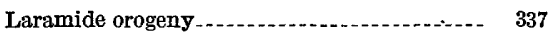 & serpentine \\
\hline Laramie and Sherman quadrangles........... & sillimanite \\
\hline Laramie River & specularite......... \\
\hline Lineation, hornblende-biotite gneiss. & sphene \\
\hline hornblende gneiss. & spinel \\
\hline gneiss & tremolite............ $\mathbf{3} 40$ \\
\hline rheomorphic quartz monzonite gneiss..... 358 & zureon $\ldots \ldots$ \\
\hline
\end{tabular}

Page

Montezuma quadrangle

Northgate district, location

North Park ........................... 335

North Park Basin _..................... 337

North Platte River

Origin, biotite-garnet gneiss

hornblende-biotite gneiss. ................ 354

hornblende gneiss........................... 341

intrusive quartz monzonite

mylonite gneiss ........................... 357

pegmatite

quartz monzonite gneiss .................. 345

Park Range ...................... 335, 364

Petrography, biotite-garnet gneiss ........... 346 dacite porphyry ..................... 364 hornblende-biotite gneiss................. 353

hornblende gneiss......... 339

in trusive quartz monzonite. ............. 365

mylonite gneiss .......................... 355

pegmatite

quartz monzonite gneiss ...................-. 343

rheomorphic quartz monzonite gneiss.-...- 359

Pinkham Creek . ......................... 350, 353

Pinkham Creek canyon

Pinkham Mountain _............... 350, 353, 365, 368

Pliocene deformation ...................... 337

Rheomorphism_................ 340, 342.357, 361, 372

Rock flowage _................. 358

Sedimentary rocks, early Tertiary _............. $\quad 337$ Mesozoic_.................. 337

North Park formation_..................... 337

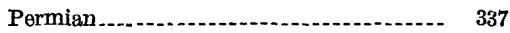

Quaternary

White River formation ........ 337

Sentinal Mountain ...................... 355, 367

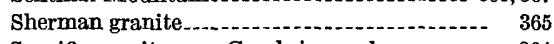

Specific gravity, pre-Cambrian rocks...-..... 364

Structural setting, rheomorphic quartz mon-

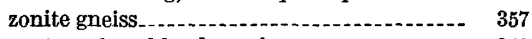

Structure, hornblende gneiss.

mylonite gneiss.............................. 356

Ultramafic masses............................ 338, 342

Ultramylonite.............

Vasquez Mountains........................... 341 


\section{PLATE 50}

A. Typical hornblende gneiss, with hornblende, $h$, and plagioclase, $p$.

$B$. Typical quartz-bearing hornblende gneiss, with hornblende, $h$, plagioclase, $p$, and quartz, $q$.

$C$. Typical pyroxene-bearing hornblende gneiss, with hornblende, $h$, augite, $p y$, and plagioclase, $p$.

$D$. Slightly altered hornblende gneiss. Plagioclase, $p$, is crowded with saussuritic inclusions; hornblende, $h$, is somewhat altered to chlorite, $c$, and epidote, $e$; small amounts of microcline, $m$, and quartz, $q$, have been introduced. 
GEOLOGICAL SURVEY
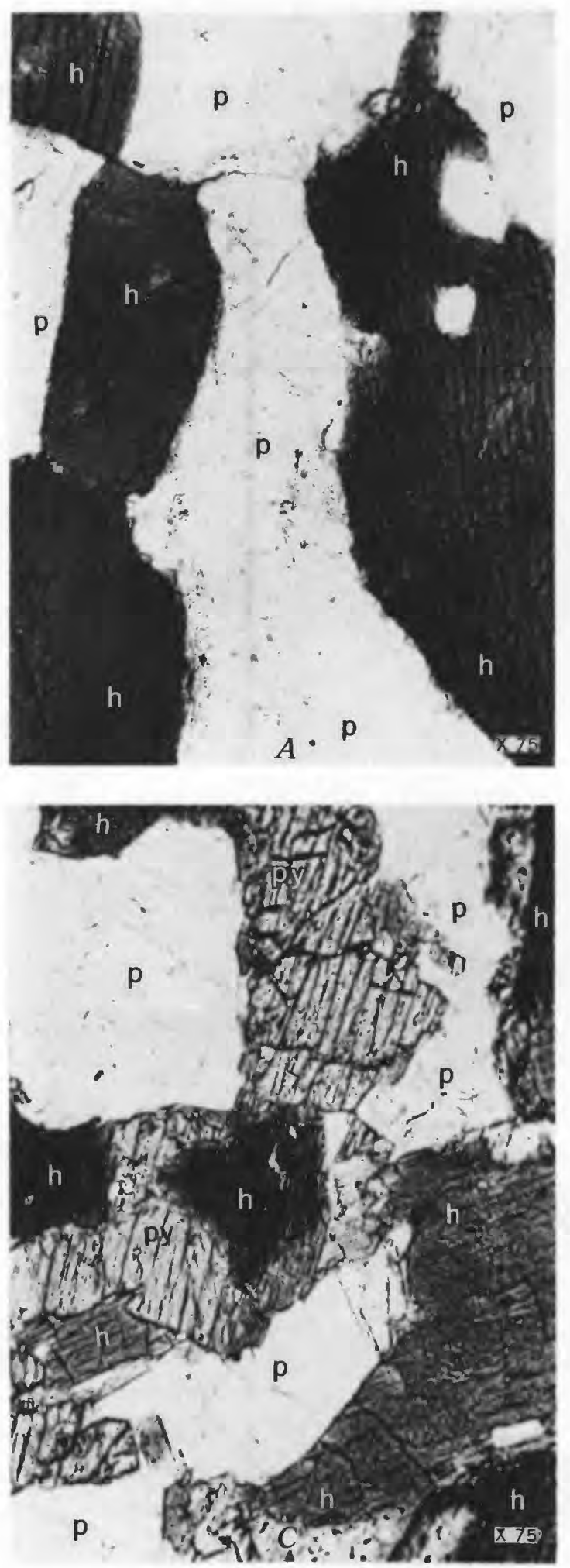
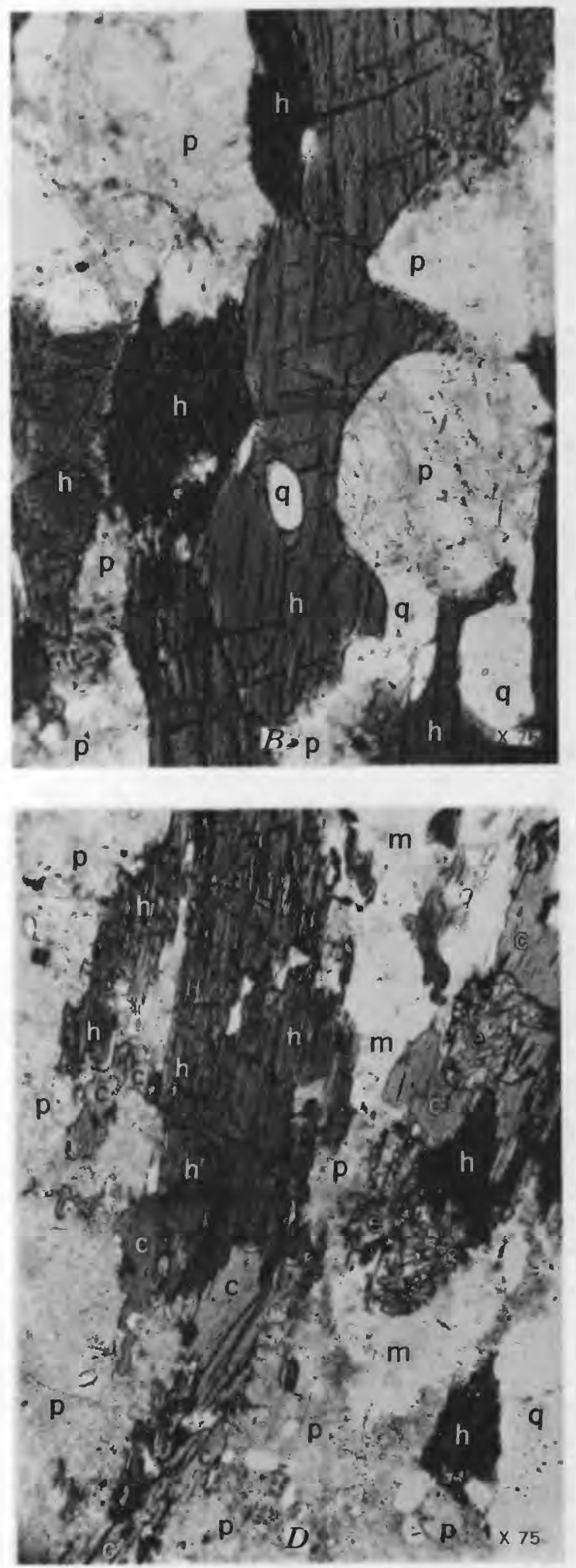

PHOTOMICROGRAPHS OF HORNBLENDE GNEISS 

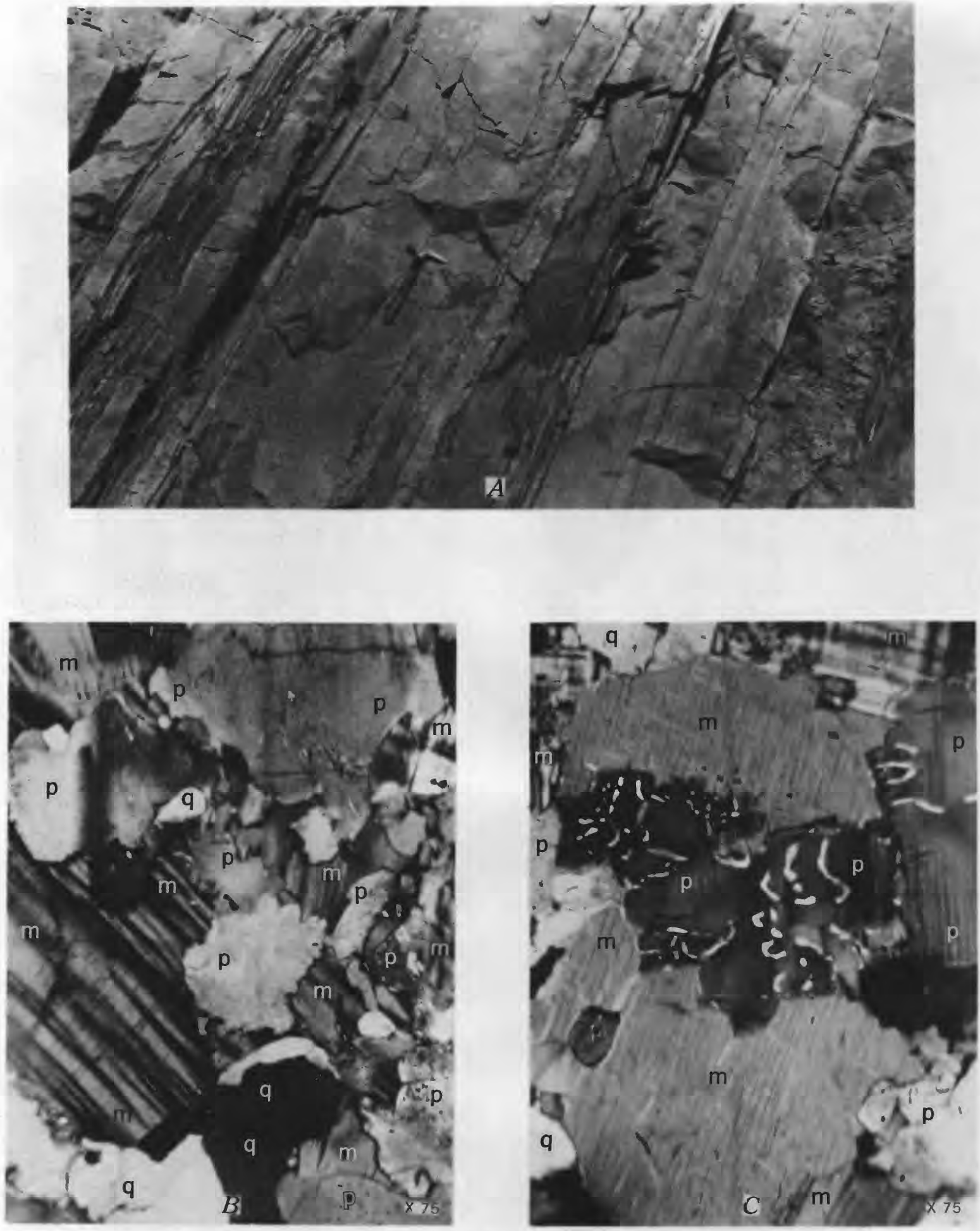

VIEW AND PHOTOMICROGRAPHS OF QUARTZ MONZONITE GNEISS 


\section{PLATE 51}

A. Typical quartz monzonite gneiss exposed in a fresh road cut along Lawrence Creek.

B. Typical thoroughly transformed quartz monzonite gneiss. Relict plagioclase grains, $p$, are corroded and replaced by microcline, $m$, and quartz, $q$.

C. Typical thoroughly transformed quartz monzonite gneiss. Relict plagioclase, $p$, enclosing secondary myrmekite is corroded and replaced by microcline, $m$, and quartz, $q$. 


\section{PLATE 52}

A. Marginal facies of biotite-garnet gneiss. Hornblende, $h$, is in part altered to biotite, $b$, quartz, $q$, and accessory apatite, $a$, and sphene (dark granules). Microcline, $m$, is a very minor constituent. Plagioclase, $p$, is essentially unaltered.

$B$. An early stage in the formation of a garnet from biotite. Scattered granules of garnet, $g$, and blue amphibole, $h$, are set in a fine-grained aggregate of quartz, plagioclase, and mica. The original biotite, $b$, is corroded, and the plagioclase, $p$, is eliminated from the area around the garnet granules. Epidote, $e$, is a common accessory.

C. Typical thoroughly transformed biotite-garnet gneiss. Irregular garnet grains, $g$, commonly poikilitic with abundant rounded blebs of quartz, $q$, and blades of biotite, $b$, are set in an aggregate of quartz, $q$, plagioclase, $p$, biotite, $b$, and generally minor microcline, $m$.

$D$. Garnet, $g$, formed at the expense of biotite, $b$, with the development of accessory apatite, $a$, and epidote, $e$. The dark granules of magnetite in the biotite apparently formed as a result of the transformation. Plagioclase, $p$, is eliminated from the garnet; quartz, $q$, commonly forms rounded blebs within the garnet, although not in this field. The reaction zone between the garnet and biotite generally is a fine aggregate of quartz, sericitized plagioclase, and pale mica.

$E$. Garnet, $g$, and secondary blue amphibole, $h$, formed at the expense of biotite, $b$. Quartz, $q$, is a common associated mineral.

$F$. Garnets developed directly from hornblende gneiss. Original hornblende, $\boldsymbol{H}$, and plagioclase, $p$, are in part replaced by quartz, $q$, and an aggregate of garnet crystals, $g$, and secondary blue amphibole, $h$. Apatite, $a$, is a common accessory. 
GEOLOGICAL SURVEY
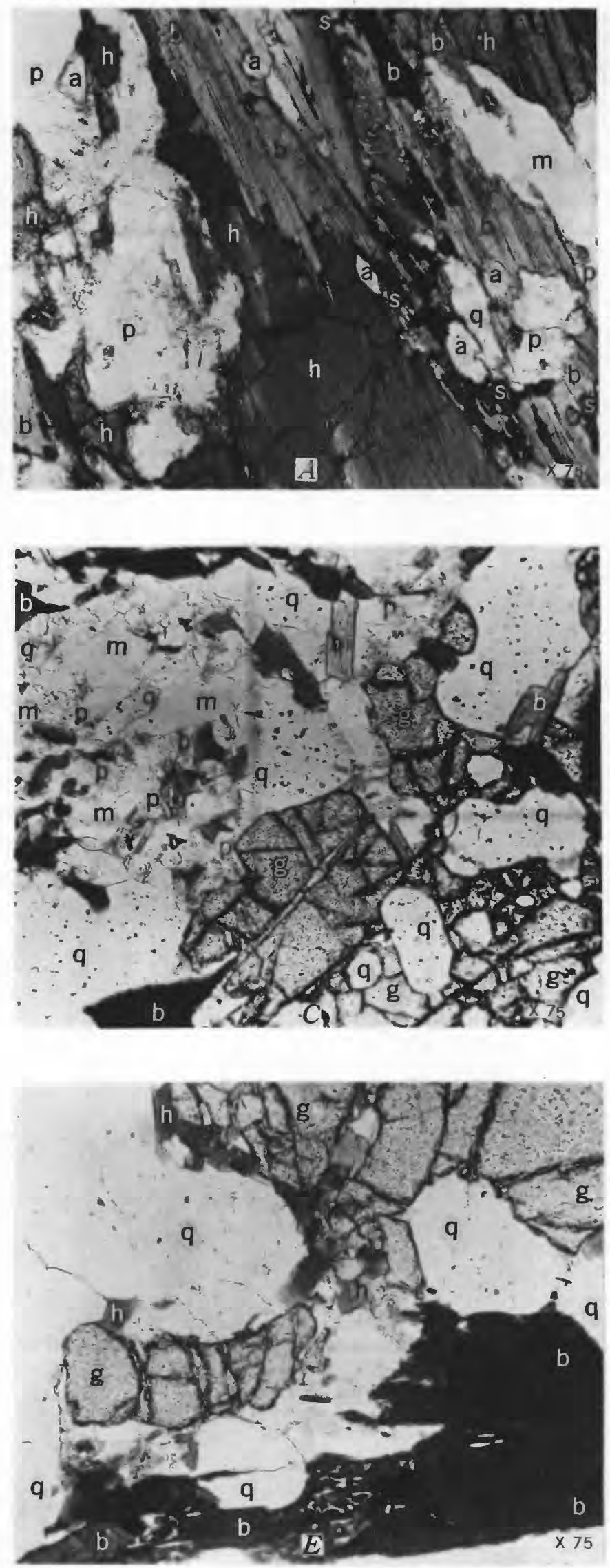

PROFESSIONAL PAPER 274 PLATE 52
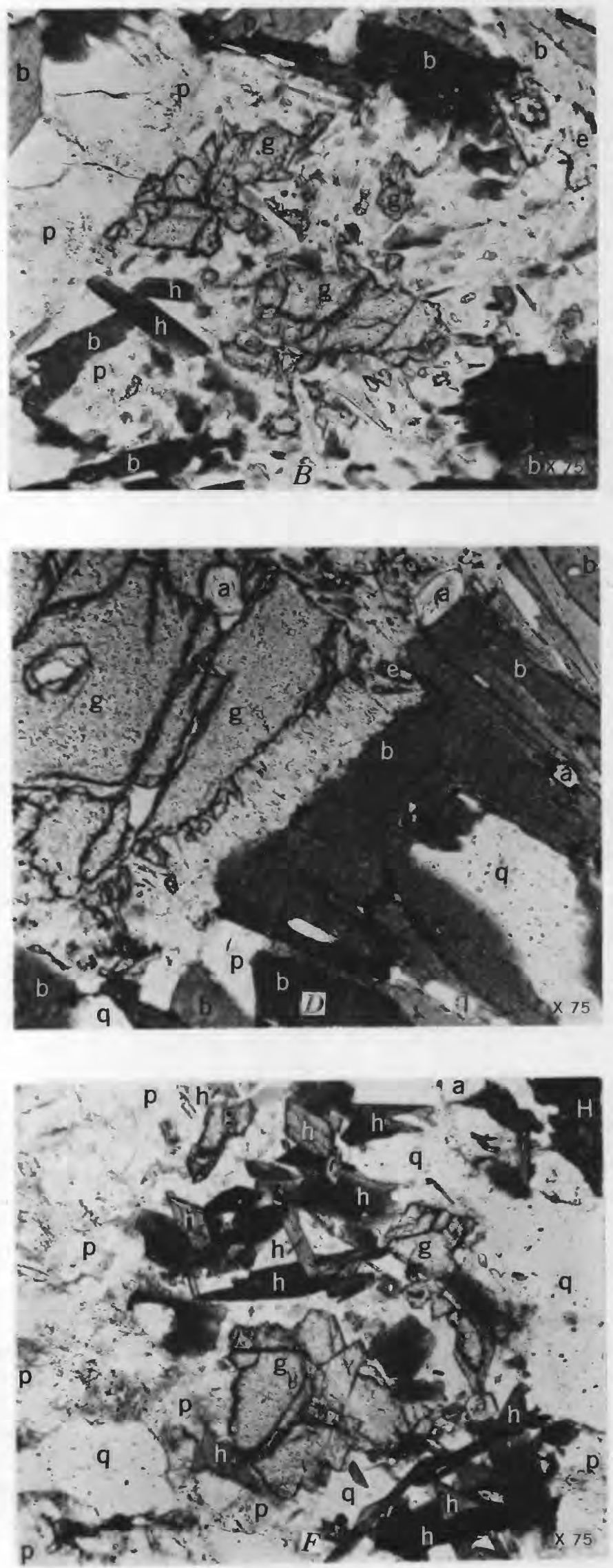

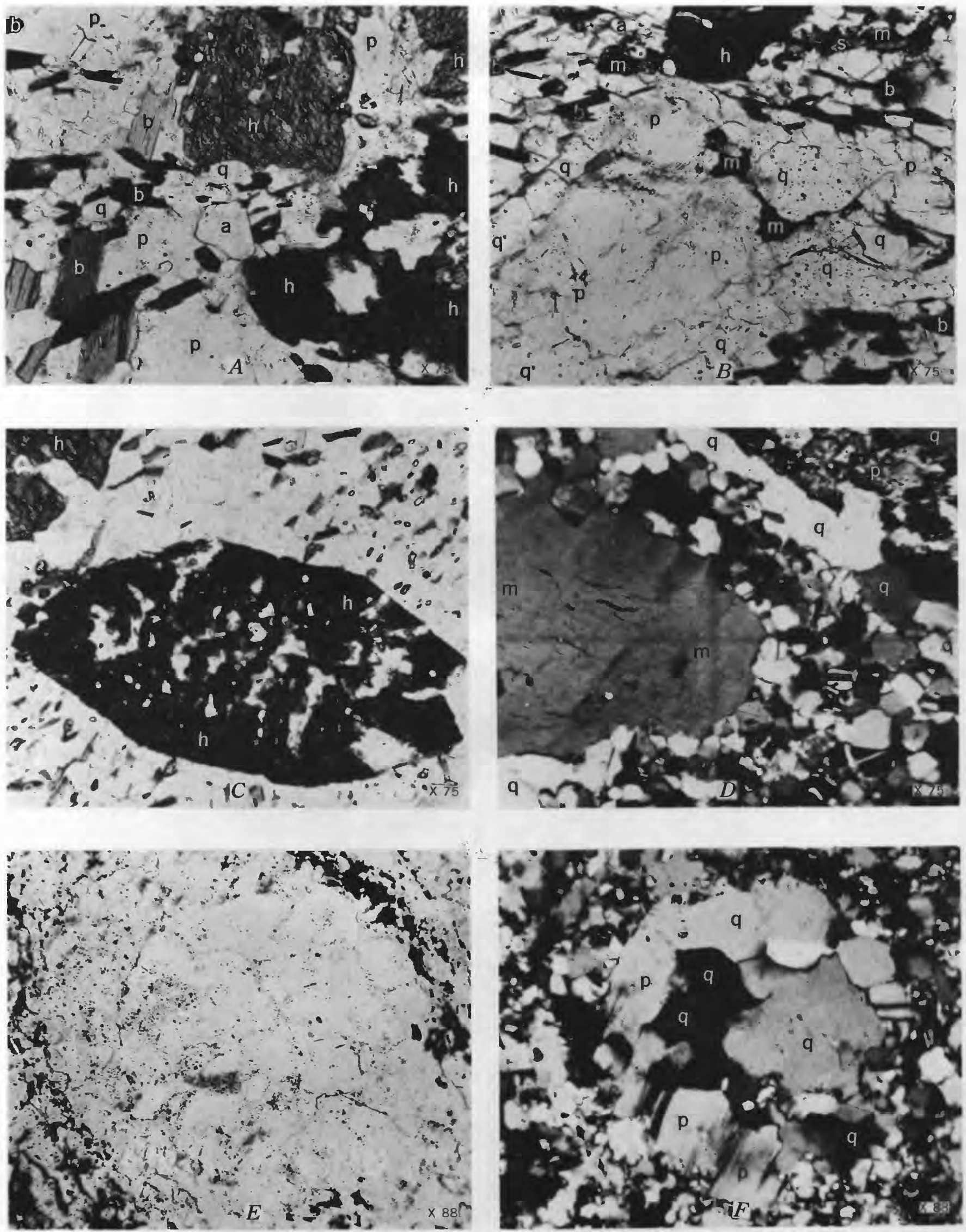


\section{PLATE 53}

A. Typical hornblende-biotite gneiss, with broken original hornblende, $h$, and plagioclase, $p$, crystals and recrystallized biotite, $b$, quartz, $q$, and apatite, $a$, along shear zones.

$B$. Mylonite gneiss derived from hornblende gneiss. Relict plagioclase, $p$, and hornblende, $h$, grains are set in a finegrained groundmass of biotite, $b$, quartz, $q$, and plagioclase, $p$. Apatite, $\boldsymbol{a}$, and magnetite, $m$, are common accessory minerals.

C. Recrystallized hornblende porphyroblast in mylonite gneiss derived from hornblende gneiss. The groundmass is largely a fine-grained aggregate of plagioclase, quartz, and biotite, with a few ragged fragments of the original hornblende, $h$.

$D$. Intermediate stages in the formation of mylonite gneiss from quartz monzonite gneiss. Relict microcline-perthite, $m$, plagioclase, $p$, and quartz, $Q$, crystals are set in a finegrained groundmass of quartz and feldspar. Recrystallized quartz, $q$, stringers mark some of the more noticeable shear planes.

$E$. Mylonite gneiss derived from quartz monzonite gneiss. In plane-polarized light the apparent augen is surrounded by a fine-grained foliated aggregate of quartz, feldspar, and hematite.

$F$. Same as $E$, under crossed nicols. The augen is shown to be a rounded aggregate of quartz, $q$, and plagioclase, $p$, fragments which has not been comminuted as finely as the groundmass. 


\section{PLATE 54}

A. Deformed plagioclase, $p$, corroded and replaced by undeformed microcline, $m$.

$B$. Deformed plagioclase, $p$, corroded and replaced by undeformed microcline, $m$, and quartz, $q$.

C. Deformed plagioclase, $p$, with myrmekitic rims, corroded and replaced by microcline, $m$, and quartz, $q$. Note the relict myrmekitic quartz bleb now surrounded by microcline, cline.

$D$. Hornblende-bearing rheomorphic quartz monzonite gneiss. Hornblende, $h$, plagioclase, $p$, and quartz, $q$, form a crystal loblastic aggregate which is in part replaced by microcline, $m$.

$E$. Hornblende gneiss from an inclusion in rheomorphic quartz monzonite gneiss. Note the almost equant grains of hornblende, $h$, and plagioclase, $p$, and the irregular grains of quartz, $q$. Apatite, $a$, is a common accessory.

$F$. Deformed early plagioclase, $p$, corroded and replaced by microcline-perthite, $m$, and quartz, $q$. Note the preferential replacement of deformed zones. 
GEOLOGICAL SURVEY
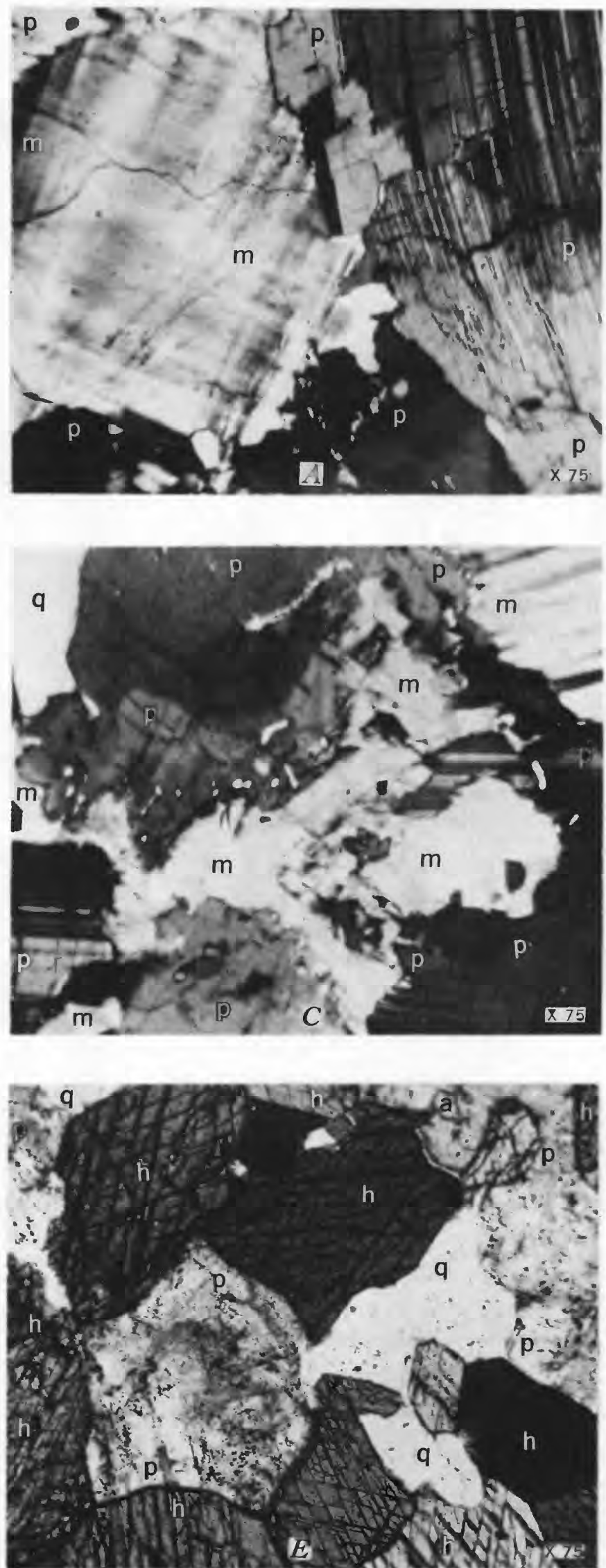

PROFESSIONAL PAPER 274 PLATE 54
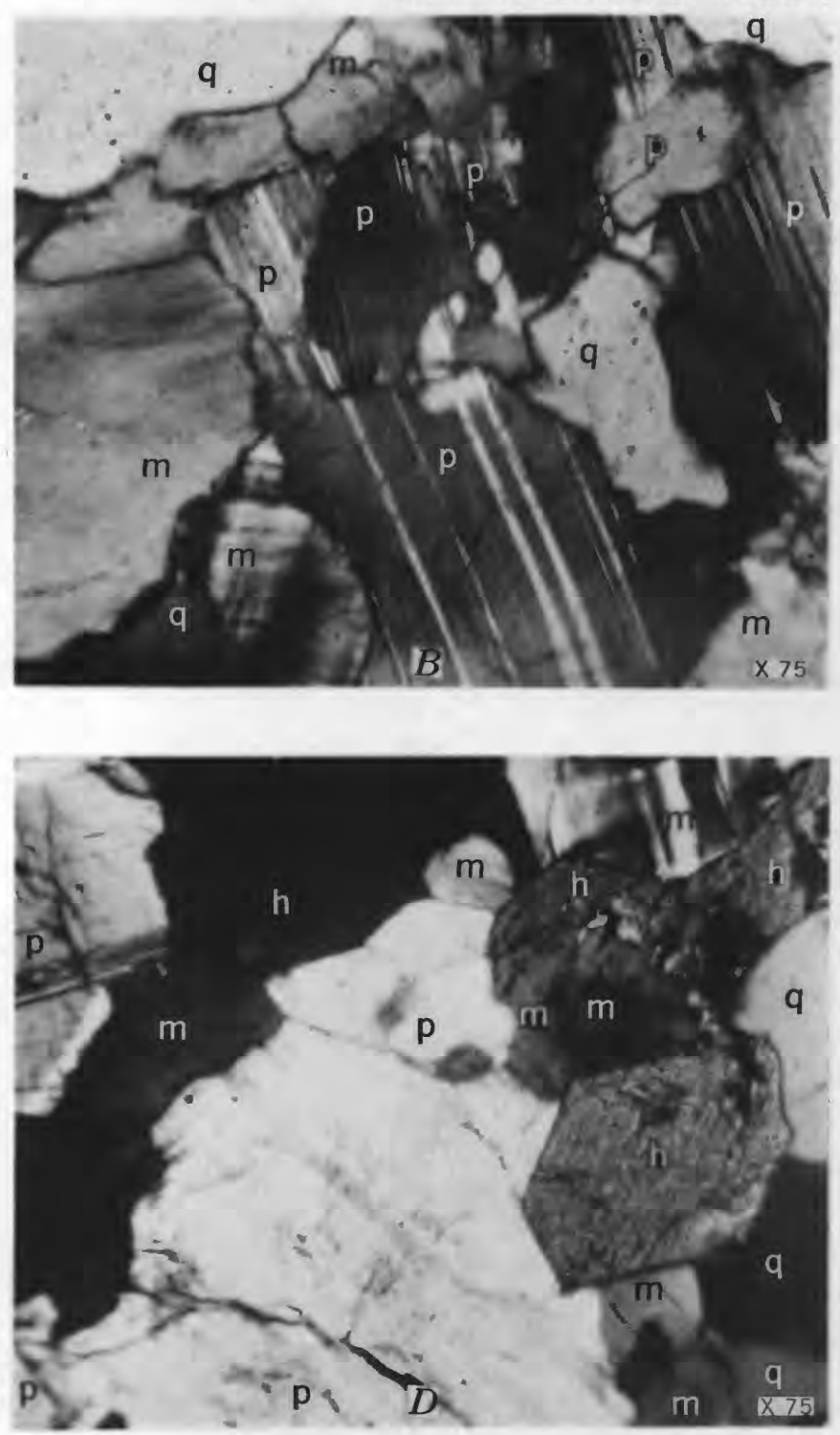
GEOLOGICAL STRVEY
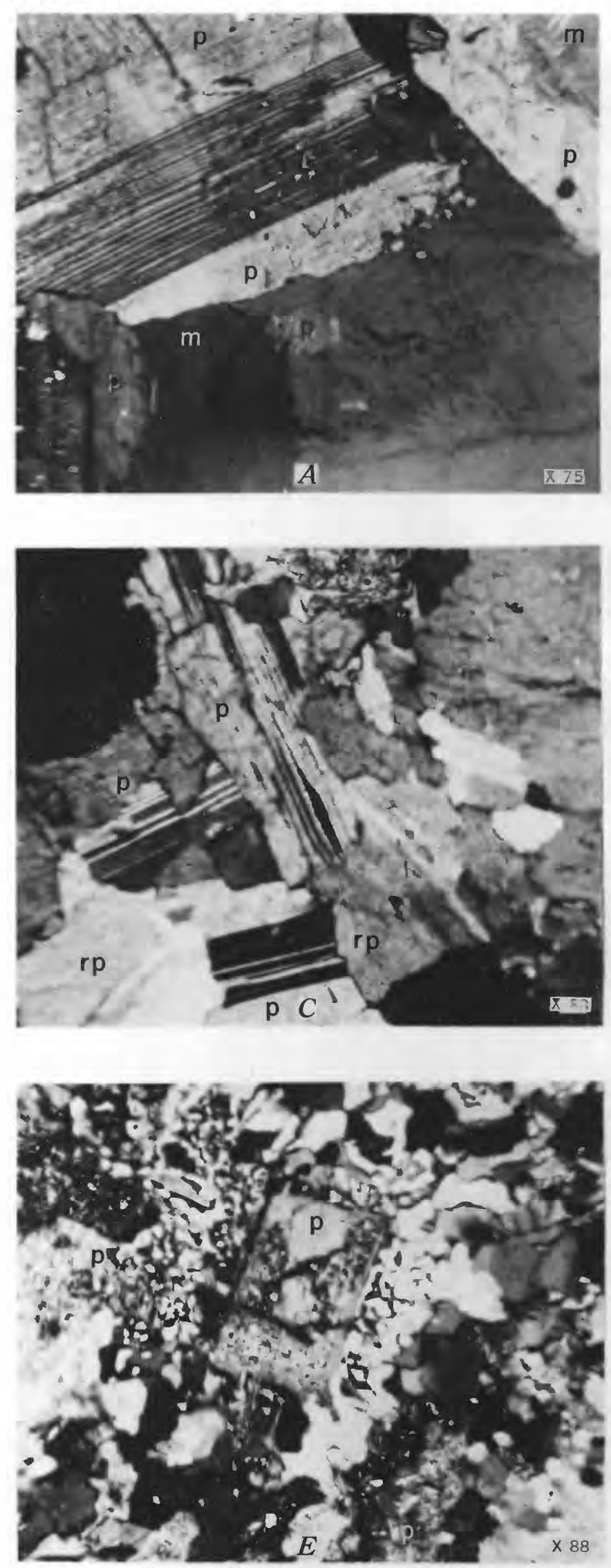

PROFESSIONAI. PAPER 274 PLATE 55
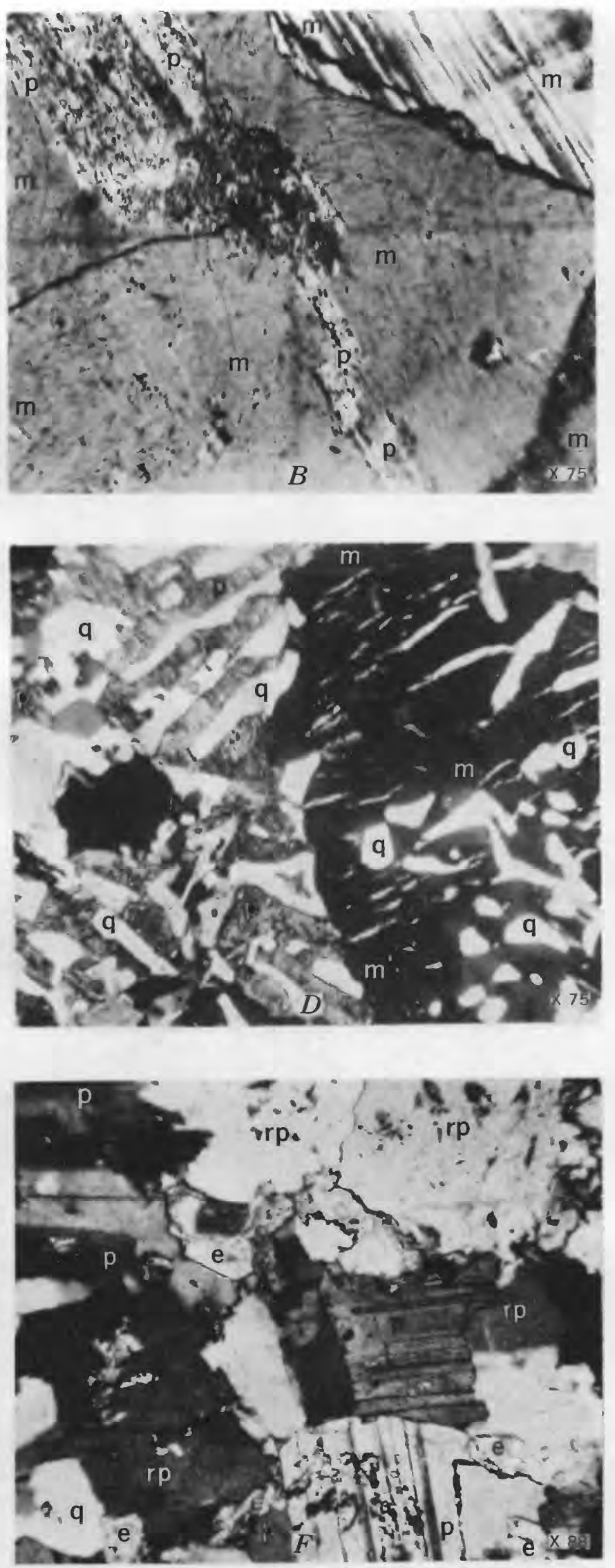
A. Early plagioclase, $p$, corroded and replaced by microclineperthite, $m$. Note the residual inclusions of plagioclase.

$B$. Highly corroded plagioclase, $p$, relict enclosed in microclineperthite, $m$.

$C$. Specimen from an area within the stock where no microcline was introduced. Deformed early plagioclase, $p$, showing relict texture is corroded and replaced by recrystallized plagioclase, $r p$, and epidote, $e$.

$D$. Pseudographic quartz, $q$, enclosed in both plagioclase, $p$, and microcline-perthite, $m$, hosts.

$E$. Specimen of a fine-grained porphyritic dike. Original plagioclase phenocrysts, $p$, enclosed in a micrographic groundmass.

$F$. Specimen from a dike which had no microcline introduced. Early plagioclase, $p$, showing relict texture is corroded and replaced by recrystallized plagioclase, $r p$, quartz, $q$, epidote, $e$, and chlorite, $c$. 



\section{Shorter Contributions}

to General Geology

1955-57

GEOLOGICAL SURVEY PROFESSIONAL PAPER 274

This Professional Paper was published

as separate chapters, $A-M$

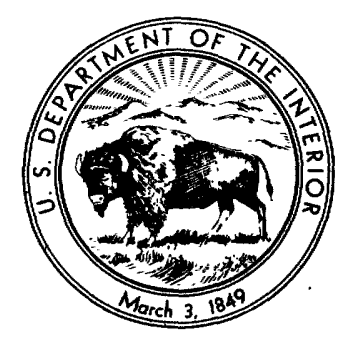

UNITED STATES GOVERNMENT PRINTING OFFICE, WASHINGTON : 1957 
UNITED STATES DEPARTMENT OF THE INTERIOR

FRED A. SEATON, Secretary

GEOLOGICAL SURVEY

Thomas B. Nolan, Director 


\section{CONTENTS}

(A) Volcanic-rich middle and upper Eocene sedimentary rocks northwest of Rattlesnake Hills, central Wyoming, by Franklyn B. Van Houten.

(B) Dakota group in northern Front Range foothills, Colorado, by Karl M. Waagé

(C) Basal Eagle Ford fauna (Cenomanian) in Johnson and Tarrant Counties, Tex., by Lloyd William Stephenson........-

(D) Characteristic Jurassic mollusks from northern Alaska, by Ralph W. Imlay

(E) Owl Creek (Upper Cretaceous) fossils from Crowleys Ridge, southeastern Missouri, by Lloyd William Stephenson...-

(F) Middle Ordovician rocks of the Tellico-Sevier belt, eastern Tennessee, by Robert B. Neuman

(G) Ecology of Foraminifera in northeastern Gulf of Mexico, by Orville L. Bandy

(H) Palmlike plants from the Dolores formation (Triassic), southwestern Colorado, by Roland W. Brown.

(I) Additions to the flora of the Spotted Ride for

(J) Fddions to the flora of the Spotted Ridge formation in central Oregon, by Sergius H. Mamay and Charles B. Read.-

(K) Stratigraphy of Middle Ordovician rocks in the zinc-lead district of Wisconsin, Illinois, and Iowa, by Allen F. Agnew,

Allen V. Heyl, Jr., C. H. Behre, Jr., and E. J. Lyons.

(L) Volcanic rocks of the El Modeno area, Orange County, Calif., by Robert F. Yerkes.

(M) Metamorphism and the origin of granitic rocks, Northgate district, Colorado, by T. A. Steven. 
. 